Distribution, Health, and Development of Larval and Juvenile Lost River and Shortnose Suckers in the Williamson River Delta Restoration Project and Upper Klamath Lake, Oregon: 2008 Annual Data Summary

Open File Report 2009-1287 



\section{Distribution, Health, and Development of Larval and Juvenile Lost River and Shortnose Suckers in the Williamson River Delta Restoration Project and Upper Klamath Lake, Oregon: 2008 Annual Data Summary}

By Summer M. Burdick, Christopher Ottinger, Daniel T. Brown, Scott P. VanderKooi, Laura Robertson, and Deborah Iwanowicz

Open-File Report 2009-1287

U.S. Department of the Interior

U.S. Geological Survey 


\section{U.S. Department of the Interior \\ KEN SALAZAR, Secretary}

\section{U.S. Geological Survey \\ Marcia K. McNutt, Director}

U.S. Geological Survey, Reston, Virginia: 2009

For more information on the USGS-the Federal source for science about the Earth, its natural and living resources, natural hazards, and the environment, visit $h$ ttp://uww.usgs.gov or call 1-888-ASK-USGS.

For an overview of USGS information products, including maps, imagery, and publications, visit $h$ ttp://huw.usgs.gov/pubprod

To order this and other USGS information products, visit http://store.usgs.gov

Suggested citation:

Burdick, S.M., Ottinger, C., Brown, D.T., VanderKooi, S.P., Robertson, L., and Iwanowicz, D., 2009, Distribution, health, and development of larval and juvenile Lost River and shortnose suckers in the Williamson River Delta restoration project and Upper Klamath Lake, Oregon: 2008 annual data summary: U.S. Geological Survey OpenFile Report 2009-1287, 76 p.

Any use of trade, product, or firm names is for descriptive purposes only and does not imply endorsement by the U.S. Government.

Although this report is in the public domain, permission must be secured from the individual copyright owners to reproduce any copyrighted material contained within this report. 


\section{Contents}

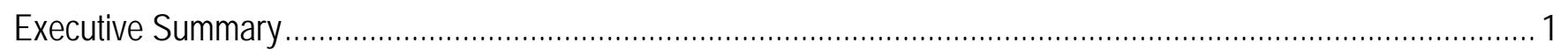

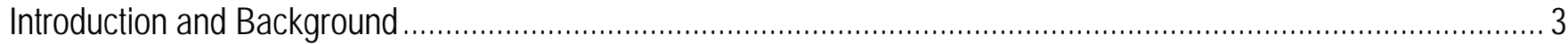

Study Area

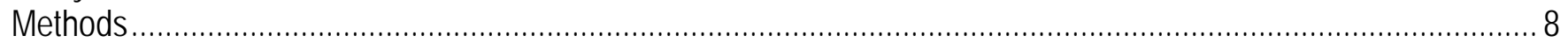

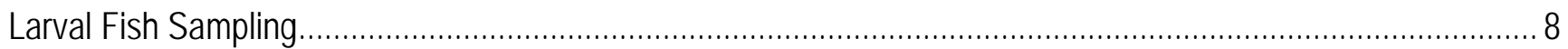

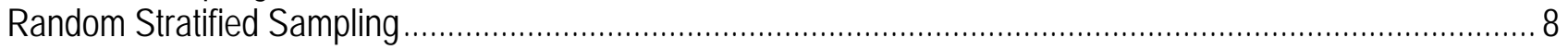

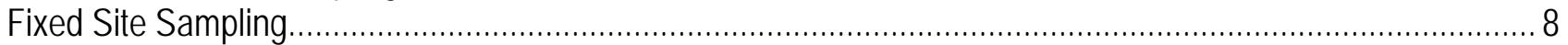

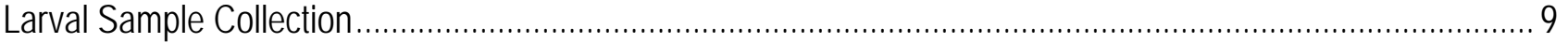

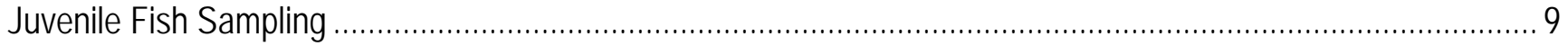

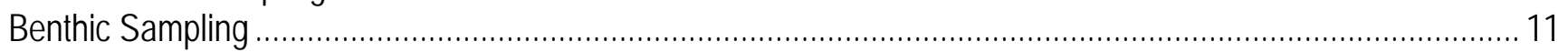

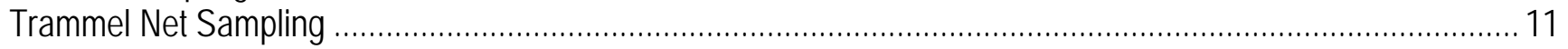

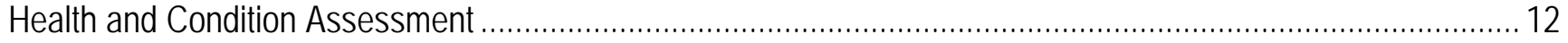

Bacterial Terminal Restriction Length Polymorphism (tRFLP) Analysis ..................................................... 13

Transforming Growth Factor- $\beta$ (TGF- $ß$ ) mRNA Expression in Age-0

Juvenile Suckers: Methods Development................................................................................. 14

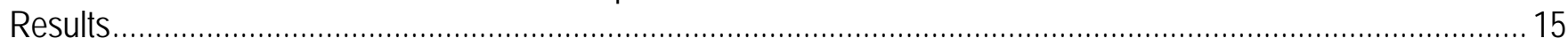

Spatial Patterns in Relative Abundance and Condition of Larval Fish ......................................................... 15

Larval Sucker Distribution, Condition, and Sample Density Relative to Hydrodynamic Conditions....................... 17

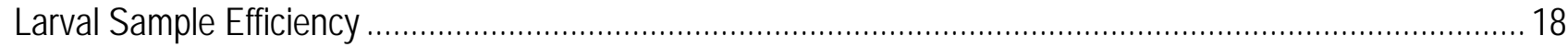

Juvenile Fish Habitat and Habitat Use .............................................................................................. 19

Juvenile Sucker Prey Availability................................................................................................. 19

Spatial and Temporal Variation in Juvenile Sucker Distribution............................................................. 19

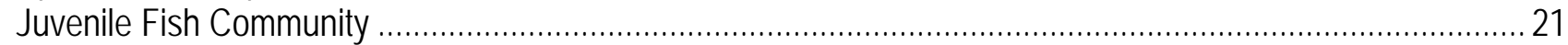

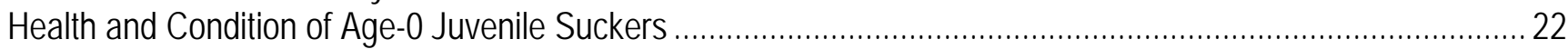

Mucosal Bacterial Communities ....................................................................................................... 22

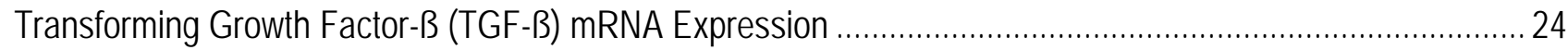

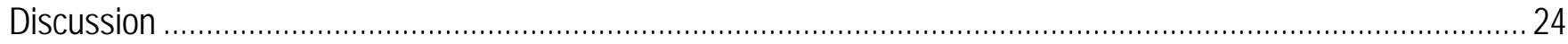

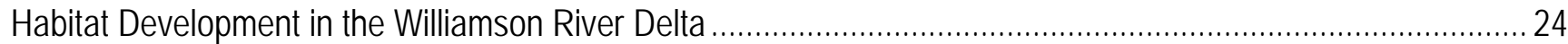

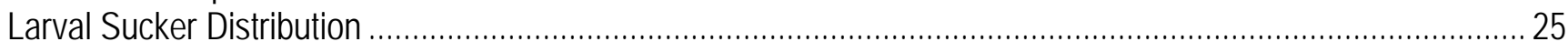

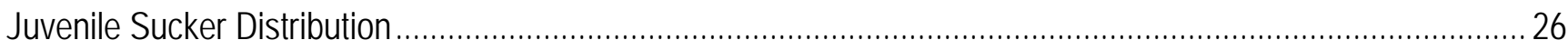

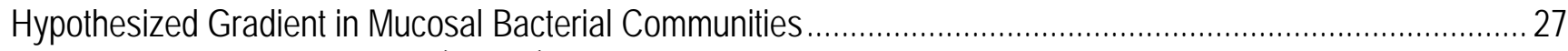

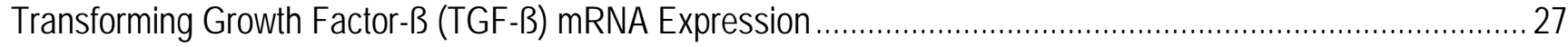

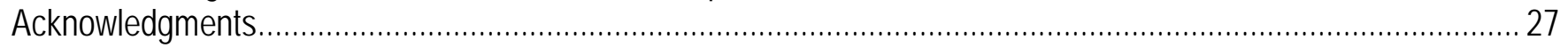

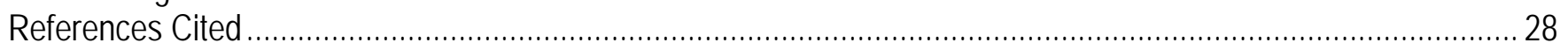




\section{Figures}

Figure 1. Map of study area in and adjacent to the Williamson River Delta, in the northeast portion of Upper Klamath Lake, Oregon

Figure 2. Map of Upper Klamath Lake study area and three defined areas of the lake ....................................... 34

Figure 3. Mean weekly sample density for Lost River sucker larvae, and a grouping of larvae identified as either shortnose or Klamath largescale suckers.

Figure 4. Mean weekly sample density of larval fish in plankton samples collected from four strata in and adjacent to the Williamson River Delta, Oregon, between May 5 and June 17, 2008.

Figure 5. Larval Lost River sucker sample densities at seven fixed sites sampled weekly in and adjacent to the Williamson River Delta, Oregon, between May 5 and July 18, 2008

Figure 6. Larval shortnose or Klamath largescale sucker sample densities at seven fixed sites sampled weekly in and adjacent to the Williamson River Delta, Oregon, between May 5 and July 18, 2008

Figure 7. Williamson River discharge and water temperature at the mouth of the Williamson River (dashed line), as measured during weekly site visits between May 5 and July 18, 2008

Figure 8. Larval sample density by week and species at seven fixed sites sampled weekly in and adjacent to the Williamson River Delta, Oregon, between May 5 and July 18, 2008

Figure 9. Length of juvenile suckers collected in trap nets set in the Williamson River Delta and southern Agency Lake, Oregon, between May 5 and September 25, 2008

Figure 10. Mean weekly catch per unit effort for age-0 suckers caught in trap nets set over night in the Tulana Unit of the Williamson River Delta and Agency Lake between June 22 and September 26, 2008.

Figure 11. Mean weekly catch per unit effort (suckers per net) for age-0 suckers caught in three areas of the Tulana Unit of the Williamson River Delta and in southern Agency Lake, between June 22 and September 26, 2008.

Figure 12. Mean catch per unit effort by 1-meter depth bins for age-0 and age-1 suckers caught in the Williamson River Delta and southern Agency Lake, Oregon.

Figure 13. Standard length of age-0 suckers caught in trap net sampling in three strata in the Tulana Unit of the Williamson River Delta and one stratum in southern Agency Lake, Oregon, between June 22 and September 25, 2008

Figure 14. Standard lengths of sacrificed age-0 Lost River suckers and shortnose suckers are shown by date of capture.

Figure 15. Mean weekly catch per unit effort for age-1 suckers caught in three areas of the Tulana Unit of the Williamson River Delta and southern Agency Lake, Oregon, between May 5 and July 25, 2008

Figure 16. Mean weekly catch per unit effort for age-1 suckers caught in trap nets set over night in the Tulana Unit of the Williamson River Delta and southern Agency Lake, Oregon, between May 5 and July 25, $2008 \ldots . . .48$

Figure 17. Standard length of age-1 suckers caught in trap net sampling in three strata in the Tulana Unit of the Williamson River Delta and one stratum in southern Agency Lake, Oregon, between May 5 and July 25, 2008

Figure 18. Number of juvenile or small adult fish caught per overnight trap net sample, by week and species........50 


\section{Figures-Continued}

Figure 19. Weekly mean catch per unit effort for two cohorts of yellow perch caught in trap nets set over night in the Tulana Unit of the Williamson River Delta and one strata in southern Agency Lake, Oregon, between May

5 and September 25, 2008

Figure 20. Percent occurrence of bacterial genera from the skin mucous of individual age-0 juvenile suckers collected from Agency Lake, Tulana Submerged Vegetation, or Tulana Open Water adjacent to Upper Klamath Lake, Oregon, July 29-September 17, 2008

Figure 21. Percent occurrence of bacterial genera from the skin mucous of individual age-0 juvenile suckers collected from near-shore areas in the southern, central, or northern regions of Upper Klamath Lake, Oregon, July 31-August 28, 2008.

Figure 22. Percent occurrence of bacterial genera from the skin mucous of individual age-0 juvenile suckers collected from off-shore or near-shore areas, within the northern region of Upper Klamath Lake, Oregon, July 28 to August 28, 2008

Figure 23. Percent occurrence of bacterial genera from the skin mucous of individual age-0 juvenile suckers collected from off-shore or near-shore areas, within the central region of Upper Klamath Lake, Oregon, July 29-August 26, 2008

Figure 24. Percent occurrence of bacterial genera from the skin mucous of individual age-0 juvenile shortnose suckers collected from near-shore areas in the southern, central, or northern regions of Upper Klamath Lake, Oregon, July 31-August 28, 2008.

Figure 25. Percent occurrence of bacterial genera from the skin mucous of individual age-0 juvenile shortnose suckers collected from Tulana Submerged Vegetation, or Tulana Open Water adjacent to Upper Klamath Lake, Oregon, July 29-September 17, 2008

Figure 26. Percent occurrence of bacterial genera from the skin mucous of individual age-0 juvenile suckers collected from Clear Lake Reservoir, Modoc County, California, September 16-18, 2008

Figure 27. Transforming Growth Factor $-\beta$ mRNA expression in putative spleen tissue from age- 0 juvenile shortnose and Lost River suckers collected in or near Upper Klamath Lake, Oregon, July 28-September $18,2008$. 


\section{Tables}

Table 1. Number of visits and mean site depth at each fixed plankton sample location in and adjacent to the Williamson River Delta, Oregon.

Table 2. Occurrence criteria applied to bacterial genera obtained in skin mucous samples from age-0 juvenile suckers collected in or near Upper Klamath Lake, Oregon, July 28-September 18, 2008. 61

Table 3. Mean sample density for Lost River and shortnose sucker larvae in random stratified plankton sampling conducted in four strata in and adjacent to the Williamson River Delta, Oregon

Table 4. Percentage of larval Lost River suckers caught in plankton nets during random stratified sampling, with $0,25,50,75$, or 100 percent of their guts full of food in four sampling strata in and adjacent to the Williamson River Delta, Oregon

Table 5. Percentage of larvae identified as either Klamath largescale or shortnose suckers caught in plankton nets during random stratified sampling, with $0,25,50,75$, or 100 percent of their guts full of food from four sampling strata in and adjacent to the Williamson River Delta, Oregon

Table 6. Mean notochord length for larval Lost River suckers and larvae identified as either shortnose or Klamath largescale suckers, collected at each of seven fixed sampling sites in and adjacent to the Williamson River Delta, Oregon.

Table 7. Number of repeat visits at sites sampled for juvenile fish in and adjacent to the Williamson River Delta, Oregon, between May 5 and September 25, 2008.

Table 8. Number of sites successfully sampled for juvenile fish in three strata in the Tulana Unit of the Williamson River Delta and one stratum in southern Agency Lake, Oregon, 2008.

Table 9. Numbers of sites at which three successful trap net samples were taken each week in three strata within the Williamson River Delta and one stratum in southern Agency Lake, Oregon......

Table 10. Taxa of invertebrates identified in benthic grab samples collected in five strata in and adjacent to the Williamson River Delta, Oregon.

Table 11. Mean species richness and diversity of juvenile and small adult fish species captured in trap nets set in three strata in the Williamson River Delta and one stratum in southern Agency Lake, Oregon

Table 12. Summary of age-0 juvenile suckers collected in or near Upper Klamath Lake, Oregon, or Clear Lake Reservoir, Modoc County, California, from July 28 to September 18, 2008 from which skin mucous samples were collected for bacterial analysis ...

Table 13. Complete taxonomic descriptions of bacterial genera obtained from the skin mucous of age- 0 juvenile suckers collected in or near Upper Klamath Lake, Oregon, or Clear Lake Reservoir, Modoc County, California, July 28-September 18, 2008.

Table 14. Example taxa in Cyanobacteria genus groups obtained from the skin mucous of age-0 juvenile suckers collected from Upper Klamath Lake, Oregon, and Clear Lake Reservoir, Modoc County, California, July 28-September 18, 2008.

Table 15. Outcome summary for age-0 juvenile sucker samples collected for transforming growth factor-ß (TGF-ß) analysis in or near Upper Klamath Lake, Oregon, or Clear Lake Reservoir, Modoc County, California, July 28-September 18, 2008 


\section{Conversion Factors}

\begin{tabular}{|c|c|c|}
\hline Multiply & By & To obtain \\
\hline \multicolumn{3}{|c|}{ Length } \\
\hline centimeter (cm) & 0.3937 & inch (in.) \\
\hline millimeter (mm) & 0.03937 & inch (in.) \\
\hline meter (m) & 3.281 & foot $(\mathrm{ft})$ \\
\hline kilometer (km) & 0.6214 & mile (mi) \\
\hline micron $(\mu \mathrm{m})$ & $3.9 \times 10^{-5}$ & inch (in.) \\
\hline \multicolumn{3}{|c|}{ Area } \\
\hline square kilometer $\left(\mathrm{km}^{2}\right)$ & 247.15 & acre \\
\hline square meter $\left(\mathrm{m}^{2}\right)$ & 10.76 & square foot $\left(\mathrm{ft}^{2}\right)$ \\
\hline \multicolumn{3}{|c|}{ Speed } \\
\hline meters per second (m/s) & 2.23 & miles per hour (mph) \\
\hline \multicolumn{3}{|c|}{ Volume } \\
\hline cubic meters $\left(\mathrm{m}^{3}\right)$ & 35.314 & cubic feet $\left(\mathrm{ft}^{3}\right)$ \\
\hline microliter $(\mu \mathrm{L})$ & $6.1 \times 10^{-5}$ & cubic inch $\left(\mathrm{in}^{3}\right)$ \\
\hline liter (L) & 0.2642 & gallon (gal) \\
\hline \multicolumn{3}{|c|}{ Volumetric Rate } \\
\hline cubic meters per second $\left(\mathrm{m}^{3} / \mathrm{s}\right)$ & 35.314 & cubic feet per second $\left(\mathrm{ft}^{3} / \mathrm{s}\right)$ \\
\hline \multicolumn{3}{|c|}{ Concentration } \\
\hline millimole (mM) & $6.022 \times 10^{-20}$ & molecules or atoms \\
\hline nanograms per milliliter (ng/mL) & 0.1335 & ounce per gallon (oz/gal) \\
\hline milligrams per milliliter (mg/mL) & $1.335 \times 10^{-4}$ & ounce per gallon (oz/gal) \\
\hline \multicolumn{3}{|c|}{ Frequency } \\
\hline kilohertz (kHz) & $1.66 \times 10^{-5}$ & rounds per minute (rpm) \\
\hline \multicolumn{3}{|c|}{ Potential Energy } \\
\hline kilovolts $(\mathrm{kV})$ & 0.001 & watt per ampere (W/A) \\
\hline \multicolumn{3}{|c|}{ Mass } \\
\hline gram (g) & 0.03527 & ounce, avoirdupois (oz) \\
\hline kilogram (kg) & 2.205 & pound avoirdupois (lb) \\
\hline
\end{tabular}

Temperature in degrees Celsius $\left({ }^{\circ} \mathrm{C}\right)$ may be converted to degrees Fahrenheit $\left({ }^{\circ} \mathrm{F}\right)$ as follows: ${ }^{\circ} \mathrm{F}=\left(1.8 \times^{\circ} \mathrm{C}\right)+32$.

Temperature in degrees Fahrenheit $\left({ }^{\circ} \mathrm{F}\right)$ may be converted to degrees Celsius $\left({ }^{\circ} \mathrm{C}\right)$ as follows: ${ }^{\circ} \mathrm{C}=\left({ }^{\circ} \mathrm{F}-32\right) / 1.8$.

Concentrations of chemical constituents in water are given either in milligrams per liter (mg/L) or micrograms per liter $(\mu \mathrm{g} / \mathrm{L})$. 


\section{Abbreviations and Acronyms}

\begin{tabular}{ll}
\hline \multicolumn{1}{c}{ Abbreviations } & \multicolumn{1}{c}{ Meaning } \\
\hline cDNA & complementary DNA \\
CPUE & catch per unit effort \\
DNA & deoxyribonucleic acid \\
DO & dissolved oxygen \\
mRNA & messenger ribonucleic acid \\
NL & notochord length \\
PCR & polymerase chain reaction \\
PIT & passive integrated transponder \\
RNA & ribonucleic acid \\
rRNA & ribosomal ribonucleic acid \\
RT- PCR & reverse transcription polymerase chain reaction \\
SE & standard error \\
SL & standard length \\
TNC & The Nature Conservancy \\
tRFLP & restriction fragment length polymorphism \\
USGS & U.S. Geological Survey \\
\hline
\end{tabular}




\section{Distribution, Health, and Development of Larval and Juvenile Lost River and Shortnose Suckers in the Williamson River Delta Restoration Project and Upper Klamath Lake, Oregon: 2008 Annual Data Summary}

By Summer M. Burdick, Christopher Ottinger, Daniel T. Brown, Scott P. VanderKooi, Laura Robertson, and Deborah Iwanowicz

\section{Executive Summary}

Federally endangered Lost River sucker Deltistes luxatus and shortnose sucker Chasmistes brevirostris were once abundant throughout their range but populations have declined; they have been extirpated from several lakes, and may no longer reproduce in others. Poor recruitment into the adult spawning populations is one of several reasons cited for the decline and lack of recovery of these species, and may be the consequence of high mortality during juvenile life stages. High larval and juvenile sucker mortality may be exacerbated by an insufficient quantity of suitable rearing habitat. Within Upper Klamath Lake, a lack of marshes also may allow larval suckers to be swept from suitable rearing areas downstream into the seasonally anoxic waters of the Keno Reservoir.

The Nature Conservancy (TNC) flooded about 3,600 acres to the north of the Williamson River mouth (Tulana Unit) in October 2007, and about 1,400 acres to the south and east of the Williamson River mouth (Goose Bay Unit) a year later, to retain larval suckers in Upper Klamath Lake, create nursery habitat for suckers, and improve water quality. In collaboration with TNC, the Bureau of Reclamation, and Oregon State University, we began a long-term collaborative research and monitoring program in 2008 to assess the effects of the Williamson River Delta restoration on the early life-history stages of Lost River and shortnose suckers. Our approach includes two equally important aspects. One component is to describe habitat use and colonization processes by larval and juvenile suckers and nonsucker fish species. The second is to evaluate the effects of the restored habitat on the health and condition of juvenile suckers. This report contains a summary of the first year of data collected as a part of this monitoring effort. 
In 2008, the newly flooded Tulana Unit of the Williamson River Delta was beginning to make the transition from upland agricultural fields to aquatic environments hospitable to suckers and other fish. Most of it was still vegetated with agricultural crops in the early stages of decomposition and resembled adjacent lake habitats more than other local wetlands. Wetland vegetation, however, was becoming established on the shallow eastern portion of the Tulana Unit. Benthic grab samples indicated food was available for larval and juvenile suckers. Nearly all species of fish commonly found in Upper Klamath Lake also were detected in the inundated portion of the delta; however, piscivorous species such as yellow perch and fathead minnows were less abundant in the delta when compared to adjacent lake habitats. The Tulana Unit of the Williamson River Delta did not appear to provide spawning habitat for yellow perch, given that no larvae of this species were caught in our study. In addition, peak larval and adult fathead minnow catches occurred after peak larval sucker catches suggesting fathead minnow predation on larval suckers may have been only a minor concern.

The Tulana Unit of the Williamson River Delta provided high quality rearing habitat for endangered larval Lost River and shortnose suckers. Larval suckers caught in this restoration area, especially areas with emergent vegetation, were feeding and typically were larger than those caught in either Upper Klamath or Agency Lake. The timing of drift relative to the Williamson River discharge, however, may influence whether or not larval suckers are retained in favorable habitat within the Williamson River Delta or swept into potentially less suitable environments in Upper Klamath Lake.

There also was some evidence of differential habitat use between larval sucker species. Catch rates in shallow water within the delta were higher for larvae identified as shortnose or Klamath largescale suckers Catostomus snyderi than for larval Lost River suckers. Catch rates at the mouth of the Williamson River, however, were higher for larval Lost River suckers than for larvae identified as either shortnose or Klamath largescale suckers.

Juveniles from three age classes and from three sucker species, including the endangered Lost River and shortnose sucker were captured in the Tulana Unit of the Williamson River Delta during the spring and summer of 2008. Spatial and temporal patterns in catch rates for these suckers throughout the Tulana Unit of the Williamson River Delta were similar to those observed for these species in other parts of Upper Klamath Lake. These trends included the use of shallow sometimes vegetated sites by age-0 suckers especially in mid- to late July and deeper unvegetated sites by older juvenile suckers.

Low dissolved-oxygen concentrations between mid-July and the end of August appeared to affect how suckers and other species used the delta. A prolonged low dissolved oxygen event coincided with the end of age- 1 and older juvenile sucker catches and low age-0 juvenile sucker catches in the Williamson River Delta. Most other fish species also appeared to be absent from the delta during at least part of this time period.

The age- 0 sucker health assessment, which included characterization of mucosal bacterial communities and quantification of Transforming Growth Factor- $\beta$ (TGF- $ß$ ) mRNA expression for detecting stress, proved a viable technique. The 2008 dataset was sparse, but set the foundation for more rigorous analysis after 2009 data collection is complete. 


\section{Introduction and Background}

Federally endangered Lost River sucker Deltistes luxatus and shortnose sucker Chasmistes brevirostris are long-lived, late-maturing fishes endemic to the Upper Klamath Basin of northern California and southern Oregon. These species are obligate lake dwellers that primarily spawn in rivers or at shoreline springs. Although once abundant throughout their range, these suckers have been extirpated from several lakes including Lower Klamath Lake, Sheepy Lake, and Lake of the Woods. It also is suspected that other populations, such as those in Tule Lake and Keno Reservoir, no longer reproduce. One of the most important remaining habitats for these suckers is Upper Klamath Lake and its tributaries, where successful spawning is known to occur (National Research Council, 2004).

The Upper Klamath Lake populations of Lost River and shortnose suckers migrate to springs located along the east shore or to the Williamson or Sprague Rivers to spawn between March and May (Ellsworth and others, 2007). Eggs are probably broadcast over gravel and cobble substrates (Ellsworth and others, 2007). Between mid-April and the end of May, larvae spawned in the river systems, emerge from gravel and drift downstream (Ellsworth and others, 2009). Larvae begin to reach the Williamson River Delta by mid-May (Ellsworth and others, 2009). When suckers reach about $14 \mathrm{~mm} \mathrm{SL}$, they most likely drop out of the drift in all but the most turbulent environments (Ellsworth and others, 2009). By June, most young-of-the-year suckers have developed fin rays and other morphological characteristics of adults, at which point they are considered juveniles (Kelso and Rutherford, 1996; Ellsworth and others, 2009). Between June and September, age-0 juvenile suckers disperse throughout Upper Klamath Lake and its' littoral marshes (Burdick and others, 2009). The period spanning their first September and their first spawning migration, which occurs between 6 and 14 years of age (Buettner and Scoppetone, 1990), has yet to be adequately described (Burdick and others, 2009).

Poor recruitment into adult spawning populations is one of several reasons cited for the decline and lack of recovery of Lost River and shortnose suckers (National Research Council, 2004). Sharp decreases in age-0 sucker catch rates during early fall and extremely low catches of age-1 or older subadult suckers (Simon and Markle, 2002; Hendrixson and others, 2007; Burdick and others, 2008) suggest poor recruitment may be the consequence of high juvenile mortality resulting from insufficient suitable habitat. For example, sub-optimal rearing habitat may restrict juvenile growth or development or may increase rates of predation by birds or other fish species.

Dissolved-oxygen concentrations that approach zero nearly every summer in the Keno Reservoir (Sullivan and others, 2009), located downstream of Upper Klamath Lake, may be a direct cause of mortality for larval and juvenile suckers within that reservoir. Wind driven water currents in Upper Klamath Lake flow in a clockwise direction and may push larvae originating from the Williamson River south along the eastern shore to the outlet of the lake and into Keno Reservoir (Markle and others, 2009). Markle and others (2009) estimate that, given nocturnal drifting behavior, it may take an average of 5 days for Lost River suckers and 20 days for shortnose suckers to be swept out of Upper Klamath Lake and into the Keno Reservoir. One way to slow transport of these larvae out of the lake is to create well-vegetated marshes that intercept fish and remove them from the main current (Markle and others, 2009). 
Historic and restored marshes can provide high quality habitat for larval suckers. Cooperman and Markle (2004) determined that established wetlands composed of emergent macrophytes support more, larger, and better-fed larvae than environments with submergent macrophytes, woody vegetation, or open water. Hendrixson (2008) also found that Riverbend, a restored wetland along the Williamson River, supported densities of well-fed larval suckers similar to established marshes and that larval densities were greater in vegetated than in unvegetated environments.

Marshes also provide important habitat for older juvenile suckers for at least part of the year. Age-0 juveniles use a wide variety of habitats throughout Upper Klamath Lake, including those characterized by stands of emergent vegetation in and around the Williamson River mouth (Burdick and others, 2009). Age-1 suckers, however, are concentrated along the edges of vegetated patches, in tributary mouths, and near springs during April and May (Markle and Simon, 1993). This age class is primarily found in open water habitats between 4 and $5 \mathrm{~m}$ deep during June and July (Burdick and others, 2009).

The Williamson River Delta probably was one of the most important wetlands for larval and juvenile suckers, due to its location downstream of known productive spawning grounds in the Williamson and Sprague rivers (fig. 1). Before the Williamson River was channelized in 1940 and the wetlands in the delta were drained and converted to farmland beginning in 1941, larval suckers probably were retained in emergent vegetation along the shorelines of the Williamson River (National Research Council, 2004). Historically, juvenile suckers may have reared for several months to several years in the emergent vegetation and deep water wetlands along marsh edges or in the marsh interior (National Research Council, 2004). More recently, larval suckers have been caught in pop-nets in Riverbend Marsh and in the Tulana Unit of the Williamson River Delta near the mouth of the Williamson River beginning in mid-May (Hendrixson, 2008). Young juvenile suckers also have been caught in Upper Klamath Lake near the Williamson River mouth as late as mid-September (Hendrixson and others, 2007).

To retain larval suckers in Upper Klamath Lake, create nursery habitat for suckers, and improve water quality in Upper Klamath Lake, TNC flooded about 3,600 acres to the north of the Williamson River mouth (Tulana Unit) in October 2007 and about 1,400 acres to the south and east of the Williamson River mouth (Goose Bay Unit) a year later (The Nature Conservancy, 2009; fig. 1). Flooding was accomplished using explosive and mechanical methods to breach (rupture to allow the passage of water) large portions of dikes separating the delta from the Williamson River, Upper Klamath Lake, and Agency Lake. The resulting gaps in the dikes are referred to in this report as breaches. Based on knowledge of maximum water depths and duration of flood tolerances of vegetation communities, TNC predicted five types of aquatic and riparian environments would become established. Three of these could potentially provide habitat for larval and juvenile suckers: open water unvegetated (2.75-3.96 m deep), deep water wetlands with submerged vegetation (1.53-2.74 m deep), and shallow wetlands with emergent vegetation (0.61-1.52 m deep; fig. 1) (David Evans and Associates Inc., 2005). One additional predicted vegetation community could potentially provide habitat for larval but not juvenile suckers: riparian or wet prairie (0.15-0.61 m deep) (David Evans and Associates Inc., 2005). Hydrodynamic models constructed prior to flooding predicted this restoration project would slow the transport of water and thus larvae between the mouth of the Williamson River and the outlet of Upper Klamath Lake (T. Wood, U.S. Geological Survey, written commun., 2007). The models indicated that currents, which were expected to flow northwest across the Tulana Unit and southwest across the Goose Bay Unit, would push larval suckers into wetland habitats that would develop in these areas (David Evans and Associates Inc., 2005; T. Wood, U.S. Geological Survey, written commun., 2007). 
Juvenile fish community structure in established neighboring marshes and open water habitats suggested the Williamson River Delta also would quickly become colonized by a number of non-sucker species, some of which pose a potential predation threat to suckers (Markle and Dunsmoore, 2007). Juvenile fish communities in two littoral marshes adjacent to Upper Klamath Lake, Upper Klamath Marsh, and Hanks Marsh are dominated by non-native fathead minnows Pimephales promelas, yellow perch Perca flavescens, and brown bullhead Ameiurus nebulosus, and native tui chub Gila bicolor (Mulligan and Mulligan, 2007; Anderson and others, 2009). Due to the presence of several tributary creeks, Upper Klamath Marsh also provides habitat for a large number of speckled dace Rhinichthys osculus (Mulligan and Mulligan, 2007). For comparison, open water habitats in Upper Klamath Lake are dominated by fathead minnows and native tui chub, blue chub G. coerulea, and Klamath lake sculpin Cottus princeps. Non-native brown bullhead and yellow perch comprised only 4 percent of fish caught in 2007 in Upper Klamath Lake (Burdick and others, 2009).

While ecological theory provides much of the essential background for planning wetland restoration projects such as the one on the Williamson River Delta, much of what is known about wetland restoration comes from trial and error. Therefore, development of a carefully planned monitoring program was essential to provide information for making adaptive management decisions as the marsh develops. Evaluation of the Williamson River Delta also is important to developing restoration plans for other marshes such as the proposed expansion to the Upper Klamath Lake National Wildlife Refuge along the western shores of Upper Klamath and Agency lakes (U.S. Fish and Wildlife Service, 2005). Given the primary goals of the Williamson River Restoration project, evaluating how and when early life stage suckers use the restored habitat, how fish assemblages change within the restored habitat as the marsh develops, and how the health and growth of suckers is affected by the restoration activities are important goals of monitoring.

A better understanding of larval and juvenile Lost River and shortnose sucker habitat use within the Williamson River Delta also could shed light on the problem of continuing poor recruitment, provide more information about the life history patterns of juvenile suckers, confirm or refute the suggestion that marsh rearing habitat is required for strong year class development, and connect physical lake processes to biological patterns. These data also may provide additional information on the effects of lake level manipulation on juvenile suckers, which could be used to aid endangered sucker recovery.

Assessment of juvenile sucker health also may be a good way to examine habitat quality because fish that rear in good quality habitat may grow faster (Songrad, 1992) and remain immunocompetent (Harms and others, 2000a). High rates of infection by bacterial pathogens may occur in habitat of poor quality if microbial community structures are dependent on habitat conditions (Westerdahl and others, 1991; Chabrillón and others, 2005). Poor quality habitat also may induce fish physiological responses that alter the levels of antimicrobial activity in the mucous and the rate of mucous production. Mucous layers provide a barrier to bacterial infection and subsequent disease.

Microbial community analysis of skin and gill mucous from both adult and juvenile Lost River and shortnose suckers was performed in 2006 (Cipriano and others, U.S. Geological Survey, written commun., 2007). Samples from adult suckers indicated shifts in microbial flora with samples in April dominated by a normal flora, August samples dominated by potential opportunistic pathogens, and October samples consisting of a flora shifting toward normal but with some persistence of the potential opportunistic pathogens. Samples from juvenile suckers obtained in August also exhibited a bacterial flora dominated by potential opportunistic pathogens and thus were similar to those obtained from adult suckers sampled in the same time period and geographic area. Numerous biotic and abiotic factors can influence microbial community composition; examples include, temperature, available nutrients, and the 
presence or absence of other microorganisms. Data provided by Cipriano and others (U.S. Geological Survey, written commun., 2007) indicate both spatial difference and temporal changes in the bacterial communities in the mucous of the Lost River and shortnose suckers in Upper Klamath Lake.

In 2008, we joined a long-term research and monitoring program to assess the effects of the Williamson River Delta restoration on the early life-history stages of Lost River and shortnose suckers. This project is a close collaboration with TNC, US Bureau of Reclamation, and Oregon State University (OSU). The goal of this collaboration is to evaluate the effects of Williamson River Delta restoration project on suckers in their first several years of life. Specifically, the partnership is interested in modeling the effect of hydrodynamics on larval retention in the restoration area and charting changes in apparent survival of juvenile suckers in relation to the reestablishment of the delta.

Responsibilities for data collection and monitoring were divided among collaborators based on their interests and areas of expertise. The Nature Conservancy took on the responsibility of monitoring the condition and relative abundance of larval suckers as they colonize the shallow $(<1 \mathrm{~m})$ environments on the eastern side of the Preserve. Researchers from OSU extended a long-term monitoring program of juvenile sucker relative abundance in Upper Klamath Lake to include the newly created shoreline in the delta. Our work was focused on documenting the use of deeper water environments on the west side of the Preserve by larval suckers.

The USGS defined five major specific objectives as a part of and in addition to the goals defined by the partnership. These include:

- Objective 1: Describe the geographic and temporal use of deep ( $>1 \mathrm{~m}$ ) water environments by larval suckers and a range of available environments by juvenile suckers within the newly restored Williamson River Delta.

- Objective 2: Quantitatively compare the probability of habitat use by juvenile suckers within habitats in the Williamson River Delta restoration area and among habitats including the restoration area and established open water areas throughout Upper Klamath Lake.

- Objective 3: Compare fish community structure in the restored Williamson River Delta to established open water areas of the lake.

- Objective 4: Describe the recolonization process in the Williamson River Delta restoration area by non-sucker species and by juvenile suckers.

- Objective 5: Compare the growth, condition, and health of juvenile suckers caught in the Williamson River Delta restoration area to suckers captured in other areas of Upper Klamath Lake. In addition, examine long-term (multi-year) trends in these factors as they relate to the reestablishment of habitat in the Williamson River Delta restoration area.

For this long-term project, we set both annual and 3-year benchmarks for reporting our results. We will produce annual data summaries as well as comprehensive reports deliverable every 3 years. Annual data summaries, like this one, are peer-reviewed open file reports intended to make data available to our partners and other resource management agencies quickly. Comprehensive, peerreviewed reports will contain analysis and interpretation of these data. Comprehensive analysis, including the results of collaborative efforts among TNC, OSU, and USGS, also may be published in peer reviewed professional journals. 


\section{Study Area}

Our study area is located in the Upper Klamath Basin of southern Oregon and northern California. We sampled a 1-km band along the shoreline of the northern end of Upper Klamath Lake, presently the largest lake in the basin, the southern one-third of Agency Lake, and in inundated portions of the Tulana Unit of the Williamson River Delta restoration project (fig. 1). We defined five sampling strata. Three strata were located in the Tulana Unit of the Williamson River Delta and were selected based on predicted plant communities expected to establish after flooding and our own depth measurements (fig. 1) (David Evans and Associates Inc. 2005). These include (1) the western portion of the Tulana restoration unit predicted to remain unvegetated (Tulana Open Water), (2) an area located in the center of the Tulana Unit predicted to establish submergent vegetation (Tulana Submergent), and (3) the eastern side of the Tulana Unit that was predicted to establish emergent vegetation (Tulana Emergent) (fig. 1). The other two strata were selected to provide a comparison with adjacent lake environments and were defined as (1) the southern one-third of Agency Lake (Agency Lake) and (2) a band of Upper Klamath Lake about $1 \mathrm{~km}$ wide located along the former southern and western shore of the Tulana and Goose Bay restoration units (Upper Klamath Lake) (fig. 1).

Within our study area, there is some variation in depth and vegetative cover but substrate, consisting primarily mud or clay with occasional patches of sand mixed with gravel and cobble, was relatively consistent. The Agency Lake stratum can be characterized as shallow (about $2 \mathrm{~m}$ ) and mostly devoid of submerged or emergent vegetation, with the exception of Agency Straits, which had deeper pockets up to $7.4 \mathrm{~m}$. The Tulana Open Water stratum is slightly deeper (about $3 \mathrm{~m}$ ) on average than Agency Lake and mostly unvegetated with only occasional stands of willows Salix spp. In this stratum, there is a pocket of deep water (4 to $6 \mathrm{~m}$ ) in the northwestern corner. Intermediate depths can be found in the Tulana Sumbergent stratum (about 1.5-2.75 m deep). In this stratum, there was very little vegetation in the spring followed by scattered patches of water smartweed Polygonum amphibium, and coontail Ceratophyllum demersum in mid- to late summer. The Tulana Emergent stratum was the shallowest part of our study area (less than $1 \mathrm{~m}$ deep). This stratum contained dense patches of tule Schoenopletcus acutus mixed with broadleaf cattail Typha latifolia, pondweed Potamogeton spp., and water smartweed interspersed between patches of open water. 


\section{Methods}

\section{Larval Fish Sampling}

In cooperation with TNC and USGS's Oregon Water Science Center, we developed a two part sampling strategy to describe the geographic and temporal use of the restored Williamson River Delta by larval suckers (objective 1). One part of the study was designed specifically to compare spatial distribution, relative abundance, and condition of larval suckers in newly restored and existing wetland habitats of the delta to adjacent lake environments. The other part of the study was designed to examine the influence of hydrodynamic processes on larval transport and residence time in the restored habitat.

\section{Random Stratified Sampling}

For the first part of this study, we randomly selected sites for sampling in several habitat types across the delta. The Nature Conservancy sampled sites in shallow habitats ( $<1 \mathrm{~m}$ deep), primarily located on the eastern side of the Tulana restoration unit, using $1.6 \mathrm{~m}$ square pop nets outfitted with fine mesh nylon (Erdman and Hendrixson, 2009). This gear type allowed sampling of the entire water column in environments with and without vegetation. To complement their monitoring program, we used a random stratified sample design to select sites from three deeper strata (> $1.5 \mathrm{~m}$ deep): (1) Agency Lake, (2) Tulana Open Water, and (3) Upper Klamath Lake (fig. 1). We sampled between 7 and 15 deep-water sites weekly between May 5 and June 17 with surface filtering plankton nets. After the study began, a concern was raised about the comparability of the sampling gears in the two studies. Therefore, we added the shallow water (0.5 to $1.1 \mathrm{~m}$ deep) Tulana Emergent stratum on the eastern side of the Tulana Unit to our sampling which overlapped with the area sampled by TNC (fig. 1). We sampled this stratum from May 27 to June 17 with the intention of providing a link between sample densities recorded by the two research groups.

\section{Fixed Site Sampling}

For the second portion of this study, sample locations were selected based on hydrodynamic model predictions of distributional patterns in respect to larval sucker age and density (T. Wood, U.S. Geological Survey, written commun., 2007). The working group selected fixed sample sites predicted to provide the greatest contrast in mean larval sucker age and density. We sampled seven fixed sites in water greater than $1 \mathrm{~m}$ deep. We visited each of these sites weekly from May 5 to July 18. Our fixed sites were located on the lake side of each of breaches 3, 4, 5, and 6, in open water in the Tulana Unit between breaches 4 and 5, in about $1 \mathrm{~m}$ of water on the east side of the Tulana Unit, and at the mouth of the Williamson River (fig. 1).

Fixed larval sample sites not only varied in distance from the Williamson River (fig. 1), the source of most larval suckers, but they also had different depths and vegetative cover. Mean depth was shallowest at the Tulana Emergent site, deepest at the Williamson River mouth and the Tulana Open Water site, and intermediate at the breach sites (table 1). Fixed sites located along the breaches were characterized by prominent tule beds and variable substrate. The Tulana Open Water site featured patches of submerged willows and fine substrate mixed with decomposing upland plant species. The Tulana Emergent site had patches of tule. The fixed site at the mouth of the Williamson River was characterized by open water with no vegetation. 


\section{Larval Sample Collection}

Plankton nets were used to collect larvae from the top of the water column. These nets had $0.3 \mathrm{~m}$ diameter mouth openings, a 2.5-m long tail, 800- $\mu$ m mesh Nitex ${ }^{\circledR}$ netting, and a removable cod end. A General Oceanics model 2030R mechanical flow meter was mounted in the mouth of each net so that volume of water sampled could be calculated. Each larval net was towed parallel to a boat at approximately $1 \mathrm{~m} / \mathrm{s}$ for 3-5 minutes or until the algae began to clog the mesh. Following the retrieval of each net, all material was meticulously removed from nets and samples were immediately stored in 70-95 percent ethanol. In addition to collecting larvae at each sampling location, we characterized environmental conditions by collecting data on water temperature, depth, and vegetation.

We collected three sequential tows at a subset of 18 percent of sites to assess sampling efficiency. These replicate tows were all started at the site origin but the direction of the tow varied slightly so that the exact same volume of water was not sampled in each replicate. We compared the catch rates among replicates to examine the degree of variability among samples.

Fish specimens were sorted from sample debris within 2 months of collection, stored in 70 percent ethanol, and later identified to species or lowest taxonomic unit practical. The first 10 larval fish of each species were measured at notochord length (NL) and all larval fish were enumerated. Larval fish were identified using gut length, body shape, and pigmentation (D. Simon, Oregon State University, written commun., 2004; Remple and Markle, 2005). Based on this method, larval suckers could be identified as Lost River suckers or either shortnose or Klamath largescale suckers. Sculpin (Cottus spp.) were identified to genus due to the lack of a suitable larval identification key for these species. Larval density for each species was calculated by dividing the total number of fish in each sample by the volume of water filtered. Following TNC's protocol (Erdman and Hendrixson, 2009), gut fullness was recorded for each sucker larvae as a percentage of the gut length that contained food in one of five categories: empty, 25 percent full, 50 percent full, 75 percent full, or 100 percent full.

We summarized larval catch data to describe spatial and temporal patterns in larval sucker presence, density, length, and gut fullness. We also summarized sample density data for all other fish species captured in our plankton tows. To avoid a negative bias in calculations of mean sample density and the percentages of sites where fish were detected, we only used samples collected on or after the first day that each species or taxa was first collected. Because all species except sculpin were detected on our last day of sampling, we did not truncate our dataset on the tail end.

Because we had separate goals for random stratified sampling and fixed site sampling, we summarized these two datasets separately. We compared the use of lake habitats to newly restored delta habitats by summarizing data from random stratified sampling. We examined the importance of Williamson River discharge and larval run timing on larval transport by summarizing larval sucker densities in our fixed site sampling.

\section{Juvenile Fish Sampling}

To address our first four objectives and to collect age-0 suckers for assessment of growth, condition, and health variables (objective 5), we used a random stratified sampling design in the restored Williamson River Delta and the southern portion of Agency Lake adjacent to the restored delta. An approximately equal number of sites were randomly selected for sampling from four strata: Agency Lake, Tulana Open Water, Tulana Submergent, and Tulana Emergent (fig. 1). Sampling in and near the Williamson River Delta coincided with sampling throughout Upper Klamath Lake that was conducted under agreement 07AA200135 with the Bureau of Reclamation and will be reported in a separate USGS open-file report. 
Juvenile fish were sampled with rectangular nets with mouth dimensions of $0.609 \times 0.914 \mathrm{~m}$, a $15-\mathrm{m}$ lead, and three internal fykes. These nets were fitted with $6.4 \mathrm{~mm}$ green nylon netting. Nets were set between 1040 and 2006 hours each day and pulled the next day between 0802 and 1831 hours for a target soak time of 20 hours for each net set. Net set and pull times as well as the depth at both the end of the lead net and the net mouth were recorded for each net. Lead and mouth depths for all three nets at each site were averaged for this data summary. At each site less than $3 \mathrm{~m}$ deep, we probed the bottom of the lake with a PVC pole and made an educated guess about substrate composition. The percentage of the entire 2,500- $\mathrm{m}^{2}$ site covered with vegetation and the portion of plants in each genus within a random $1-\mathrm{m}^{2}$ sample also was recorded.

We allocated effort differently by season. Between May 5 and June 18, hereafter referred to as spring, we set one trap net at 21 sites and three trap nets at 11 sites. Between June 23 and August 4, hereafter referred to as mid-summer, we set three nets at 208 sites. Between August 5 and September 25, hereafter referred to as late summer, we set a single trap net at 248 sites and three trap nets at six sites. When three nets were set at one site, the mouth openings were arranged to be approximately 120 degrees to each other to avoid interference among nets. This sample allocation was designed to capture age- 1 and older juvenile suckers in spring, the peak of age- 0 sucker abundance in mid-summer, and the decrease of age- 0 sucker abundance in the late summer. We delineated these time periods based on historic catch data for age-0 and age-1 suckers (VanderKooi and others, 2006; Burdick and others, 2007; Hendrixson and others, 2007; Burdick and others, 2009).

Captured fish were identified to species or lowest practical taxonomic group and counted. For all suckers, standard length (SL) was measured and the presence of deformities and macroparasites were noted. When catches exceeded $3 \mathrm{~kg}$, a subsample was taken for all species except juvenile suckers. Prior to subsampling, the presence or absence of each species in the entire sample was recorded in four size bins: tiny < $40 \mathrm{~mm} \mathrm{SL}$, small 40-100 mm SL, medium 100-200 mm SL, and large $\geq 200 \mathrm{~mm} \mathrm{SL}$. All suckers were then removed from the sample and measured. Subsamples were taken by placing the entire sample in a large water-filled tub, thoroughly mixing the contents of the tub, and removing approximately 30 percent of the original sample weight using a dip net. The total number of individuals of each species, except suckers, in the total catch was estimated by extrapolation using the ratio of subsample weight to total weight. Subsample species composition was assumed representative of total catch. Catch per unit effort (CPUE) was not calculated as fish per hour for each species because there were not apparent relations between the number of fish captured and the length of time that nets were in the water. Instead, we report the number of fish of each non-sucker taxa per net set.

Healthy suckers $70 \mathrm{~mm}$ SL or longer collected during spring sampling were injected with full duplex, 12.45 X 2.02 mm, 0.106 g, $134.2 \mathrm{kHz}$, cylindrical passive integrated transponder (PIT) tags. Suckers were tagged as a preliminary step in understanding movement patterns in relation to environmental variables and in validating estimates of age to maturity. Suckers that were not emaciated, had no external macroparasites, were free of deformities, and had no lesions or other wounds were considered healthy. Prior to tagging, suckers were scanned for the presence of a tag and anesthetized in a 0.02 to $0.03 \mathrm{mg} / \mathrm{L}$ solution of MS-222, which was prepared with lake water. All suckers were allowed to remain in the solution until they did not respond to stimulus (probing with net or stick). All taggers were trained using preserved specimens prior to tagging live fish. Between each injection, needles were sterilized with Nolvasan. Wounds were not closed with sutures and no antibiotics were administered. 
Tagged suckers were allowed to recover in a bucket of lake water prior to being transferred to $0.21-\mathrm{m}^{3}$ net pens, where they were held overnight to assess tagging survival and tag loss. Net pens were suspended about $0.5 \mathrm{~m}$ off the substrate at the locations where fish were originally captured. Upon retrieval of the pens, the number of sucker mortalities and tags lost were recorded before live suckers were released at their location of capture.

About one-third of captured juvenile suckers $70 \mathrm{~mm}$ SL or less and one-tenth of suckers 70 to $145 \mathrm{~mm}$ SL were sacrificed and preserved in 95-percent denatured ethanol for identification to species. We identified juvenile suckers to species in the laboratory with a method developed by Markle and others (2005) using a combination of techniques including vertebrae enumeration, lip morphology, and gill raker counts. The estimated number of each sucker species in a catch was obtained by multiplying the species proportion in the subsample of sacrificed fish by the total number of juvenile suckers caught in the sample. We classified suckers as age-0, age-1, or older based on weekly length frequency plots.

Juvenile sucker catch data were summarized to describe spatial-temporal patterns in distribution and relative abundance and age and length structure in the sampled population. Catch data for other species was summarized to describe timing and distribution of individual species and diversity and structure of communities. We described community structure and species richness for each sample using the Shannon-Wiener index of diversity (McCune and Grace, 2002). The Shannon-Wiener index is a way of describing the information content in a given community and describes not only the diversity but the evenness among species. A high Shannon-Wiener index indicates more equal representation of species in a community or sample.

\section{Benthic Sampling}

To determine the presence of prey resources in the newly inundated delta, we used a Petite Ponar grab sampler to collect benthic invertebrates from a randomly selected subset of sites also sampled for juvenile fish. We collected a variable amount of material from each site depending on bottom substrates. Water and fine sediments were sifted from each sample in the field using an 800-micron wire mesh sieve. The remainder of the sample was then preserved in 70-90 percent ethanol mixed with Rose Bengal, a dye that improves sample sorting efficiency. Invertebrates were removed from the samples in the laboratory and identified to the lowest practical taxa. The presence or absence of each taxa identified was recorded (table 10).

\section{Trammel Net Sampling}

We set one trammel net each week between May 5 and August 25 to monitor the newly inundated Williamson River Delta and adjacent lake habitats for large piscivorous fish that may prey upon or compete with juvenile endangered suckers. Trammel nets were $100 \mathrm{~m}$ long, $1.8 \mathrm{~m}$ high, with two 30-cm mesh outer panels, a 3.8-cm mesh inner panel, a foam core float line, and a lead core bottom line. The location of the trammel net was rotated between the Agency Lake, Tulana Open Water, and Upper Klamath Lake strata. These nets were set between 0826 and 1128 hours and checked approximately hourly for 4 hours before they were removed from the water. Actual soak times ranged from 3 hours and 45 minutes to 5 hours and 10 minutes for a grand total of 89.8 hours. Species and standard length was recorded for each fish caught in the trammel nets. This effort resulted in a total catch of nine tui chub between 222 and $289 \mathrm{~mm}$ SL. Three of these were caught in Agency Lake and the other six were caught in Upper Klamath Lake. Sucker predators were not detected in our trammel net sampling. 


\section{Health and Condition Assessment}

We examined suckers collected in this study and a simultaneous study conducted in Upper Klamath Lake under Reclamation agreement number (07AA200135) to examine seasonal and spatial differences in the health and condition of age-0 juvenile suckers in the Williamson River Delta and adjacent lake environments (objective 5). In addition, we sampled in Clear Lake Reservoir in northern California for comparison to a presumed healthy population. These fish were collected during four weeks (July 27, August 10, August 24, and September 14) that spanned a range of summer waterquality conditions in the delta and Upper Klamath Lake (Wong and others, 2009). We attempted to sample nearly equal numbers of fish during each of the week long sampling periods and from each of six strata. Strata included Tulana Submergent, Tulana Open Water, Agency Lake, and strata located in southern, central, and northern Upper Klamath Lake. Within Upper Klamath Lake the southern region was defined as south of Sesti Tgawaals Point and Hagelstein Park, the northern region was defined as north and west the mouth of the Williamson River and Eagle Point, and the central region the portion of the lake in between (fig. 2). We defined strata within each region in Upper Klamath Lake as either within $100 \mathrm{~m}$ of shore (near shore) or more than $100 \mathrm{~m}$ from shore (off shore).

Our approach included two equally important aspects. First, we examined mucosal bacterial communities for the presence of infectious pathogens and indications of healthy mucous production. Infection by bacterial pathogens through mucosal surfaces is dependent on the existing mucosal bacterial flora at the time of exposure (Westerdahl and others, 1991; Chabrillón and others, 2005), on components of innate immunity including lysozyme (Fletcher and White, 1973), proteases (Aranishi and Nakane, 1997), antimicrobial peptides (Park and others, 1998; Silphaduang and others, 2006), and on mucous sloughing. Changes in the mucous bacterial flora can arise when changes in habitat quality or other stressors alter the overall microbial community structure or induce fish physiological responses that alter the levels of antimicrobial activity in the mucous or the rate of mucous production. In multiple fish species, stress is known to have a major impact on the epidermal cells that produce mucous (Iger and others, 1995; Quiniou and others, 1998; Nolan and others, 2000; van der Salm and others, 2000, 2002). Therefore, the second aspect of our health analysis was to determine if our study animals had experienced relatively elevated levels of stress.

We examined relative stress levels in age-0 juvenile suckers by quantifying the expression of Transforming Growth Factor - Beta (TGF-ß) in mRNA. TGF-ß is a highly conserved cytokine associated with concentration dependent regulation of multiple immune functions in fish (Harms and others, 2000a). This cytokine is expressed in an inverse relationship with cortisol (Harms and others, 2000b) and has been directly related to immune function in field studies (Harms and others, 2000a). To adjust for natural variation in total mRNA production among individual fish at a given time, we standardized against the expression of Beta - actin ( $($ - actin), a general maintenance protein expressed consistently (constant percent of total mRNA) though time within individuals. A high ratio of TGF-ß to $ß$ - actin indicates more immune system activation and can be interpreted as a high level of stress. 


\section{Bacterial Terminal Restriction Length Polymorphism (tRFLP) Analysis}

Sucker skin mucus was collected midline using a sterile inoculating loop and placed into a sterile cryovile with $200 \mu \mathrm{L}$ TE (10mM Tris-HCl pH 8, 1mM EDTA) buffer. Samples were frozen immediately on dry ice and maintained at $-80^{\circ} \mathrm{C}$ until DNA was extracted. Following modified methods of Smith and others (2007), the mucus and TE buffer was thawed, spun at 13,000 rpm for 10 minutes and the buffer was aspirated off the sample leaving only the mucoid pellet. Lysozyme $(20 \mathrm{mg} / \mathrm{mL})$ was directly added to the mucus pellet and incubated for 30 minutes at $37^{\circ} \mathrm{C}$ before extraction began. Nucleic acids were then extracted from the sample using the DNeasy Blood and Tissue Kit (Qiagen) following the modification for gram positive bacteria.

For terminal restriction fragment length polymorphism (tRFLP) analysis, bacterial 16S rRNA genes were initially amplified using the polymerase chain reaction (PCR) with unlabelled primers F63 (5'-CAGGCCTAACACATGCAAGTC-3') and R1389 (5'-AGCGGCGGTGTGTACAAG-3'). All primers were purchased from Integrated DNA Technologies. PCR reactions were carried out following those in Smith and others (2007). The PCR product was purified with QIAquick PCR Purification Kit (Qiagen), quantified on a Nanodrop ND-8000 spectrophotometer (Nanodrop Technologies/ThermoFisher Scientific) and normalized to $25 \mathrm{ng} / \mu \mathrm{L}$. The purified product was then used in a second PCR reaction using labeled F63-D4 and R1389 primers. To the labeled PCR product, $5 \mu \mathrm{L}$ of universal buffer was added, each sample divided into 3, $10 \mu \mathrm{L}$ aliquots, and the resulting mix digested with a restriction enzyme. Each triplicate PCR product was individually digested with CfoI, MspI, and RsaI (New England Biolabs) respectively, for $2 \mathrm{~h}$ at $37^{\circ} \mathrm{C}$. After digestion, $5 \mu \mathrm{L}$ of digest was desalted by ethanol precipitation in the presence of glycogen $(5 \mu \mathrm{g})$ following Beckman Coulter protocol. The final product was resuspended in deionized formamide and $0.5 \mu \mathrm{L}$ of Beckman Coulters DNA size standard Kit -600 was added. The samples were analyzed using a Beckman Coulter CEQ 8000 Genetic Analysis System for $60 \mathrm{~min}$ at $4.8 \mathrm{kV}$. Digestion fragment sizes and peak heights were determined with Beckman Coulter CEQ Fragment Analysis Software, using a quadratic polynomial to size the fragments, a percentage peak value of 1 percent, and a slope threshold of 20.

The tRFLP profiles for each digestion were separated by individual fish and analyzed using a tRFLP phylogenetic assignment tool (PAT; NTL-LTER T-Rflp Package, Microbial Observatory-North Temperate Lakes Long-Term Ecological Research Center for Limnology, University of WisconsinMadison, http://trflp.limnology.wisc.edu/index.jsp). The bacterial identifications were updated by matching the PAT results with the taxonomic nomenclature found in the Ribosomal Data Base Project (RDP) Release 10, Update 12 (June 10, 2009; Michigan State University, http://www.msu.edu/).

Only bacteria identified to genus were considered in this report. Presented genera were filtered based on the number of base mismatches required for F63 primer to 16S rRNA gene binding. Only those genera in which the primer could bind with one or fewer mismatches were considered. The genera were further filtered using occurrence criteria, where occurrence was defined as the percentage of fish from a specific geographic area in which a given bacterial genus was obtained. Bacteria identified from suckers collected in areas near or within Upper Klamath Lake were filtered following the occurrence criteria in table 2 using the data obtained from fish captured in Tulana Open Water, Tulana Submergent, and in near-shore habitats from each of the three regions in Upper Klamath Lake. These areas were selected based on the number of samples obtained $(n \geq 10)$. The resulting list of genera was applied to all geographic areas in or near Upper Klamath Lake. The Clear Lake Reservoir bacterial genera were filtered using a 50 percent or higher detection criteria. This percentage was selected to approximate the percent of genus inclusion obtained for Upper Klamath Lake. 
Transforming Growth Factor-ß (TGF-ß) mRNA Expression in Age-0 Juvenile Suckers: Methods Development

Spleen and liver tissues were harvested from adult Lost River and shortnose suckers collected along the eastern shore of Upper Klamath Lake. Spleen tissue was targeted for the measurement of TGF- $§$ mRNA expression because the organ has been shown to yield high expression levels in other fish species (Harms and others, 2000a, 2000b). Organ fragments were harvested from the fish immediately following euthanasia, placed into RNAlater (Ambion/Applied Biosystems), refrigerated for $24 \mathrm{~h}$ at $4^{\circ} \mathrm{C}$ and then frozen at $-80^{\circ} \mathrm{C}$.

Our first step was to develop primers that could extract TGF- $\beta$ and $\beta$-actin expressed in mRNA. Genomic DNA was extracted from liver tissue of adult Lost River and shortnose suckers using a DNeasy kit (Qiagen). RNA was extracted from spleen tissue from the same fish using an RNeasy kit (Qiagen), then reverse transcribed using TaqMan Reverse Transcription Reagents (Applied Biosystems) to produce cDNA. Primers designed for conserved regions of TGF- $\beta$ and $\beta$-actin were used to amplify regions of TGF- $\beta$ (cDNA) and $\beta$-actin (cDNA and genomic DNA) using PCR. PCR products were cloned using a TA cloning kit (Invitrogen) and sequenced using Big Dye Terminator Cycle Sequencing reactions (Applied Biosystems).

We examined the similarity of $\beta$-actin and TGF- $\beta$ in cDNA between Lost River and shortnose suckers, to determine if separate primer sets were needed for each sucker species. $\beta$-actin in the cDNA from an internal fragment of the $\beta$-actin gene from Lost River sucker was sequenced. Genomic DNA from the same region of the shortnose sucker $\beta$-actin gene also was sequenced. This internal fragment of $\beta$-actin was predicted to span an intron. The Lost River sucker and shortnose sucker sequences differ at only one nucleotide in the exon sequences. Therefore, the same primer set could be used for both species. TGF- $\beta$ cDNA from an internal fragment of the TGF- $\beta$ gene was sequenced for Lost River sucker and shortnose sucker. This internal fragment covered four predicted intron splice sites, based on comparison to the zebrafish tgfb1 gene. The Lost River sucker and shortnose sucker TGF- $\beta$ coding regions are 88 percent identical over an 850 base pair region. The difference in the TGF- $\beta$ sequence between these species meant that separate primer sets were needed for Lost River and shortnose suckers.

TGF-b expression in YOY Suckers: We quantified the expression of TGF- $\beta$ in YOY suckers by extracting TGF- $\beta$ from mRNA from spleen tissue or liver tissue if spleen tissue was unavailable. RNA was extracted from tissue samples using RNeasy kits (Qiagen) and treated with DNase to remove genomic DNA. RNA was then quantitated using a Nanodrop ND-8000 spectrophotometer. The quality of the RNA isolated from a subset of the samples was determined using a Bioanalyzer automated microfluidics system (Agilent Technologies). Target gene (TGF- $\beta$ ) and control gene ( $\beta$-actin) expression were measured in duplicate for each sample by two-step quantitative reverse transcription PCR (RT-PCR). Spleen RNA was reverse transcribed using the Taqman Reverse Transcription Reagents (Applied Biosystems), then quantitative PCR was performed on an ABI7900HT system (Applied Biosystems) using Power SYBR Green Master Mix (Applied Biosystems). Primers for realtime PCR were designed using Primer Express (Applied Biosystems). Only predicted intron regions for $\beta$-actin, and TGF- $\beta$ were targeted to avoid amplification of genomic DNA. Average target gene expression relative to average control gene expression was reported. 


\section{Results}

\section{Spatial Patterns in Relative Abundance and Condition of Larval Fish}

We collected 150 larval samples at 102 sites between May 5 and July 18 from four strata: Upper Klamath Lake, Agency Lake, Tulana Open Water, and Tulana Emergent (fig. 1). The average ( \pm SE) volume of water filtered per site was $16.7 \pm 3.63 \mathrm{~m}^{3}$. Single tows were collected at 78 sites and triplicate tows were collected from 24 sites. Water surface temperature at random stratified sites ranged from 13.9 to $22.8{ }^{\circ} \mathrm{C}$ and varied widely during the larval sampling period with no apparent warming trends (fig. 3). Seventy-four percent of open water sites selected for random stratified sampling was completely devoid of vegetation. The other 26 percent of sites had small clumps of willows, tule, pondweed, and broadleaf cattail.

We identified 114 Lost River suckers and 25 suckers as either shortnose or Klamath largescale suckers in our random stratified samples. One sucker could not be identified to species due to inadequate preservation resulting in decomposition of the specimen. Lost River suckers made up 81 percent of the suckers caught in our random stratified sampling and were captured at 19 percent of sites. Whereas the group of fish identified as either shortnose or Klamath largescale suckers made up 19 percent of suckers and were captured in 15 percent of sites. Both sucker taxa co-occurred in only 6 percent of our random stratified samples. The overall mean $( \pm$ SE) density (larvae per cubic meter of water filtered) in these samples between May 20 and July 17 was $0.069 \pm 0.026$ for larval Lost River suckers compared to only $0.016 \pm 0.004$ for the group of fish identified as either shortnose or Klamath largescale suckers.

Both groups of suckers first appeared in our random stratified samples in Upper Klamath Lake during the week of May 18 (fig. 3). Both Lost River suckers and the group of fish identified as either shortnose or Klamath largescale suckers were captured in the Tulana Emergent stratum during the following week (fig. 3). During the week of May 25, larvae identified as shortnose or Klamath largescale suckers also were detected in the Tulana Open Water stratum, but Lost River suckers were not detected in that stratum until the week of June 1 (fig. 3). Following these initial arrivals, larvae from both groups were captured at variable rates across all strata (fig. 3).

There were some patterns in the distribution and catch rates for suckers among strata. The percentage of sample sites where Lost River sucker were detected was greatest in the Tulana Emergent stratum (50 percent) followed by Upper Klamath Lake (24 percent), the Tulana Open Water stratum (16 percent), and Agency Lake (7 percent). The percentage of sample sites where larvae identified as either shortnose or Klamath largescale sucker were detected were greatest in the Tulana Emergent stratum (50 percent) followed by the Tulana Open Water stratum (21 percent), Agency Lake (7 percent), and Upper Klamath Lake (6 percent). Mean sample densities for both sucker taxa were approximately an order of magnitude greater in the Tulana Emergent stratum than in the Tulana Open Water or Agency Lake strata (table 3). The mean sample density for larval Lost River suckers in Upper Klamath Lake was only slightly lower than in the Tulana Emergent stratum. For larvae identified as either shortnose or Klamath largescale suckers, the densities were only one-half as high as in the Tulana Emergent stratum (table 3). 
The mean notochord ( \pm SE) length for the group of larvae identified as either shortnose or Klamath largescale suckers (13.26 mm NL \pm 0.45$)$ was greater than for Lost River suckers (12.42 mm $\mathrm{NL} \pm 0.06$ ) captured in our random stratified sampling. On average, larval Lost River suckers were slightly larger in the Williamson River Delta $(12.97 \pm 0.15 \mathrm{~mm} \mathrm{NL}, \mathrm{n}=29)$ than in Upper Klamath Lake (12.27 $\pm 0.04 \mathrm{~mm} \mathrm{NL}, \mathrm{n}=82)$ and Agency Lake $(11.33 \pm 1.58 \mathrm{~mm} \mathrm{NL}, \mathrm{n}=3)$. For the group of larvae identified as either shortnose or Klamath largescale suckers, the largest were caught in the Williamson River Delta (mean $13.94 \mathrm{~mm}$ NL, $\pm 0.30 \mathrm{SE}, \mathrm{n}=9$ ) followed by Agency Lake (mean 13.75 mm NL, $\pm 0.09 \mathrm{SE}, \mathrm{n}=2$ ) and Upper Klamath Lake (mean $12.75 \mathrm{~mm}$ NL, $\pm 0.78 \mathrm{SE}, \mathrm{n}=14$ ).

Eighty-eight percent of larval Lost River suckers and all larvae identified as either shortnose or Klamath largescale suckers had some food in their guts, but there was some variation in median gut fullness among strata (tables 4 and 5). Seventy-nine percent of Lost River suckers had guts between 25 and 75 percent full, 12 percent had empty guts, and 9 percent were full. Fifty percent of shortnose or Klamath largescale suckers' guts were between 25 and 50 percent full and 50 percent were 75 to 100 percent full. For Lost River suckers, median gut fullness was highest in the Tulana Emergent stratum (75 percent full), intermediate in the Tulana Open Water (63 percent full) and Agency Lake strata (50 percent full), and lowest in Upper Klamath Lake (25 percent full). Median gut fullness for larvae identified as either shortnose or Klamath largescale suckers was highest in Upper Klamath and Agency lakes (both 75 percent full), intermediate in the Tulana Emergent stratum (63 percent full), and lowest in Tulana Open Water (25 percent full). The only larvae to have empty guts were Lost River suckers caught in Agency Lake ( $\mathrm{n}=1)$ and Upper Klamath Lake $(\mathrm{n}=12)$ between May 20 and June 10.

In addition to suckers, we captured larvae of four other fishes common to Upper Klamath Lake in our random stratified plankton sampling. A total of 361 larval fish were identified as non-sucker species, but 24 of these were not identifiable to a lower classification due to poor preservation leading to decomposition of the individuals. When averaged over the time that each species was present in our samples, mean $( \pm$ SE) sample densities for blue chub $(0.052 \pm 0.014)$ and fathead minnow $(0.084 \pm$ $0.029)$ were lower than for tui chub (0.191 \pm 0.056$)$, but similar to those for Lost River suckers (0.069 \pm $0.026)$ and shortnose or Klamath largescale suckers $(0.016 \pm 0.005)$ (fig. 4). The least common taxon in our random stratified larval sampling was sculpin which was only detected at one sample site in Upper Klamath Lake on May 20 (fig. 4).

There were some differences in the species composition and timing of larval fish use among strata. Larval sample densities peaked in the Tulana Emergent and Agency Lake strata the week of June 8, but were highest in the Upper Klamath Lake stratum the week of May 18 and the Tulana Open Water stratum the week of June 15. The first non-sucker larvae to be detected in our sampling were blue chub and sculpin, both captured the week of May 18 in Upper Klamath Lake (fig. 4). Tui chub were first captured the following week in the Tulana Open Water stratum. Then during the week of June 8, fathead minnow larvae were captured in all four strata. Lost River suckers dominated larval sucker catches in Upper Klamath Lake during the week of May 18. In 3 of the 4 weeks that followed, however, they were a small part of catches in that stratum, but made up a larger portion of catches in the Tulana Emergent stratum (fig. 4). 


\section{Larval Sucker Distribution, Condition, and Sample Density Relative to Hydrodynamic Conditions}

We collected 78 larval samples between May 5 and July 18 from seven fixed sites that were visited weekly (fig. 1). Single tows were collected on 60 occasions and triplicate tows were collected on 6 occasions. The average ( \pm SE) volume of water filtered per site was $14.0 \pm 1.3 \mathrm{~m}^{3}$.

Water temperature at fixed sites (fig. 5) ranged from 14.4 to $18.9^{\circ} \mathrm{C}$ during the weeks of May 5 and June 9. This period was followed by generally increasing water temperatures at all sites except the Williamson River mouth and Tulana Emergent, which decreased slightly during the week of July 14 (fig. 5). Maximum water temperatures recorded during larval sampling were $23.0^{\circ} \mathrm{C}$ at all sites except breach 3 where the water temperature reached $24.4^{\circ} \mathrm{C}$ the week of July 14 .

We identified 431 larvae as Lost River suckers and 81 as either shortnose or Klamath largescale suckers from our fixed site samples. We were unable to identify three individuals to any taxa other than Catostomidae due to inadequate preservation resulting in decomposition of the specimens. Lost River suckers made up 84 percent of the Catostomids caught at fixed sites. Out of the seven fixed sites, Lost River suckers were caught at five (fig. 5) and larvae identified as either shortnose or Klamath largescale were caught at four (fig. 6). Both sucker taxa co-occurred in only 9 percent of our fixed site samples. The overall mean density in these samples was $0.44 / \mathrm{m}^{3}$ for larval Lost River suckers as compared to $0.08 / \mathrm{m}^{3}$ for larvae identified as either shortnose or Klamath largescale suckers.

Nearly all Lost River sucker larvae caught in our sampling were captured at the mouth of the Williamson River (93 percent). Of these, 78 percent were caught on either May 20 or May 27, when water temperature was measured at 17 and $16{ }^{\circ} \mathrm{C}$, respectively (fig. 5). Discharge from the Williamson River was high (1,620 to $\left.1,710 \mathrm{ft}^{3} / \mathrm{s}\right)$ during this period, but below the seasonal peak of $2,070 \mathrm{ft}^{3} / \mathrm{s}$ recorded on June 3 (fig. 7). A few larval Lost River suckers also were caught at the Tulana Emergent site (4 percent) and the rest were caught at breach 3, breach 6, and at the Tulana Open Water site. In contrast, 75 percent of larvae identified as either shortnose of Klamath largescale suckers captured in our fixed site sampling were caught at the Tulana Emergent site on June 24 or June 30. Discharge from the Williamson River on these days was relatively low (608 to $700 \mathrm{ft}^{3} / \mathrm{s}$ ) and water temperature ranged from 13 to $22{ }^{\circ} \mathrm{C}$. The second largest portion (19 percent) of larvae identified as either shortnose of Klamath largescale suckers were caught at the mouth of the Williamson River between May 20 and July 7 under a wide range of temperature and flow conditions (fig. 6).

The mean length for Lost River suckers $(11.98 \mathrm{~mm} \pm 0.05 \mathrm{SE})$ was less than for the group of larvae identified as either shortnose or Klamath largescale suckers (12.96 mm $\pm 0.25 \mathrm{SE}$ ) captured in our fixed site sampling. Larval Lost River suckers' mean length was lowest at breach 6, intermediate at the mouth of the Williamson River and Tulana Open Water, and greatest at the Tulana Emergent and breach 3 sites (table 6). However, the number of larval suckers caught at sites other than the Williamson River mouth was low, which prevented us from making meaningful comparisons. For the group of larvae identified as either shortnose or Klamath largescale suckers, mean length was greatest at the Tulana Open Water site followed by the Tulana Emergent site and the mouth of the Williamson River (table 6). A single $9 \mathrm{~mm}$ (NL) larva identified as either a shortnose or Klamath largescale sucker was caught outside of breach 5 . 
Eighty-two percent of larval Lost River suckers and 95 percent of larvae identified as either shortnose or Klamath largescale suckers caught in our fixed site sampling had some food in their digestive systems, but there was some variation in median gut fullness among sites. All sucker larvae of both taxonomic groups with empty digestive systems were caught at the mouth of the Williamson River. For Lost River suckers, median gut fullness was highest at the Tulana Emergent (75 percent full) and Tulana Open Water (75 percent) sites. Median gut fullness estimates for Lost River sucker larvae caught at breach 6 (37 percent), breach 3 (25 percent), and the Williamson River mouth (25 percent) were much lower. For the group of larvae identified as either shortnose or Klamath largescale suckers, median gut fullness also was highest at the Tulana Emergent site (75 percent) followed by the Tulana Open Water site (63 percent) and lowest at the Williamson River mouth (25 percent) and breach 5 (25 percent).

In addition to suckers, we captured larvae of three other species in our fixed site plankton sampling. Larval blue chub were first recorded at the mouth of the Williamson River on May 20. Fathead minnow larvae were first detected at four of our fixed sampling sites (Williamson River mouth, Tulana Open Water, breach 3, and breach 4) the week of June 10 and at all seven sites the following week. Larval tui chub were first caught at Tulana Open Water and breach 4 sites the week of June 1 and were eventually detected at all sites except breach 6 and the Williamson River Mouth (fig. 8). When averaged over the time that each species was present in our samples, mean ( \pm SE) sample densities for blue chub $(0.18 \pm 0.08)$ and fathead minnow $(0.78 \pm 0.44)$ were greater than for tui chub $(0.13 \pm 0.04)$.

There was some spatial and temporal heterogeneity in species composition in our fixed site sampling. Larval Lost River suckers dominated catches at the Williamson River mouth between the weeks of May 18 and June 8 (fig. 8). Then during the weeks of June 1 and June 8, tui chub dominated catches at the Tulana Open Water site (fig. 8). Fathead minnows dominated catches at breach 6 and the mouth of the Williamson River between the weeks of June 28 and July 13 and at breach 5 during the weeks of June 28 and July 5 (fig. 8). Larvae identified as either shortnose or Klamath largescale dominated catches at the Tulana Emergent site during the week of June 28 (fig. 8).

\section{Larval Sample Efficiency}

There was a high degree of variability in sample densities between replicate tows at sites for both Lost River sucker larvae and larvae identified as either shortnose or Klamath largescale suckers. At sites where replicate tows were conducted, Lost River sucker larvae were captured at only 10 and larvae identified as either shortnose or Klamath largescale suckers were captured at only 7. Lost River suckers were detected in all three replicate tows on only three occasions and in two of three replicate tows only once. Larvae identified as either Klamath largescale suckers or shortnose suckers were never captured in all three replicate tows and were captured in two of three tows on only three occasions. The mean ( \pm SE) difference between the highest and lowest sample densities among replicates was $3.75( \pm 3.17)$ for Lost River suckers and $0.23( \pm 0.14)$ for larvae identified as either shortnose or Klamath largescale suckers. Larval density in our samples did not degrade with each sequential tow, suggesting repeat tows did not cause a bias in our assessment of sampling efficiency. 


\section{Juvenile Fish Habitat and Habitat Use}

During 21 weeks of sampling in southern Agency Lake and the Williamson River Delta, we set 940 trap nets overnight at 218 sites for a grand total of 19,780 hours of soak time. One-half of all sites were visited only once, although others were visited up to five times (table 7), resulting in a total of 492 site visits (table 8) in 2008. Nets were set in triplicate on 225 occasions and most of these sets occurred in mid-summer (204) (table 9). The duration of trap net samples ranged from 15.5 to 26.2 hours and averaged $21.6 \pm 0.06$ hours. By design, most site visits occurred in either the mid-summer (205) or late summer (255) sample periods. We subsampled 37 catches that weighed between 2.0 and $7.7 \mathrm{~kg}$.

Four nets failed during mid-summer sampling and were not included in this data summary. Three of these were located at one site in the Tulana Emergent stratum and were judged to be ineffective because the lake-surface elevation declined overnight leaving most of the nets out of the water. The cod end of the fourth net came untied as the net was retrieved, causing the majority of the catch to escape.

There was not a clear relationship between the number of hours that a net was in the water and the number of fish captured. Therefore, we summarized our catches in terms of the number of fish per net, rather than the number of fish per hour.

\section{Juvenile Sucker Prey Availability}

To determine if food was available for juvenile suckers in the newly inundated wetland, we recorded the presence and absence of 15 invertebrate taxa from 148 benthic grab samples collected in the newly restored Tulana Unit of the Williamson River Delta and adjacent lake environments. The density or abundance of each taxa was not estimated due to time constraints. We detected four taxa that are known prey of juvenile suckers $30 \mathrm{~mm}$ SL or longer (Markle and Clauson, 2006). Benthic crustaceans and larval diptera, the main food source for juvenile suckers, were common in our samples from all three strata in the Tulana Unit and from Upper Klamath and Agency lakes (table 10).

\section{Spatial and Temporal Variation in Juvenile Sucker Distribution}

We captured a total of 340 suckers in the Tulana Unit of the Williamson River Delta and Agency Lake. Based on weekly length frequency distributions, we estimate approximately 87 percent of these suckers were age- 0 juveniles, 12 percent were age-1, and 1 percent were age-2 (fig. 9). We sacrificed 132 age- 0 and 5 age- 1 suckers for identification to species, histology, or collection of tissues for our fish health study. The largest portion of sacrificed age-0 suckers were Lost River suckers (46 percent) followed by shortnose suckers (28 percent) and suckers identified as having intermediate characteristics of Lost River, shortnose, or Klamath largescale suckers (21 percent). A much smaller portion was identified as Klamath largescale suckers (5 percent). Of the five sacrificed age- 1 suckers, three were identified as Lost River suckers and two were identified as having intermediate characteristics of Lost River, shortnose, or Klamath largescale suckers.

\section{Age-0 Juvenile Suckers}

Age-0 suckers recruited to our nets the week of June 22 (fig. 9). After that, weekly mean catch rates (suckers per net) and the percentage of nets to catch at least one sucker for this age class increased until the week of August 24 then decreased slightly before increasing again the week of September 21 (fig. 10). Lost River suckers were the first sucker species to be detected in our nets as age-0 juveniles in 2008 (fig. 10). Catch rates for this species increased between the weeks of June 22 and July 13, were not detected the week of July 20, were detected again the week of July 27, and then consistently increased 
until the week of September 7 (fig. 10). Age-0 shortnose suckers were first detected in our nets the week of July 13. Catch rates for this species increased until the week of August 3, decreased slightly the week of August 17, and then spiked up to a seasonal high the week of August 24 (fig. 10). Only six age-0 Klamath largescale suckers were detected in our sampling; two each in the Agency Lake, Tulana Open Water, and Tulana Submergent strata. We also recorded relatively high catches of fish having intermediate characteristics of Lost River, shortnose, or Klamath largescale suckers beginning July 13 (fig. 10).

Age-0 Lost River and shortnose suckers were first detected in the Tulana Emergent stratum in less than $1 \mathrm{~m}$ of water (fig. 11). Mean weekly catch rates peaked in the Tulana Emergent stratum the week of July 13, decreased by more than one-half the week of July 20 (fig. 11), and then the stratum became too shallow to sample. The week of July 27, age-0 sucker catch rates also began to increase in the Tulana Open Water and Agency Lake strata, but remained low in the Tulana Submergent stratum (fig. 11). During the week of August 24, catch rates decreased by more than 50 percent in the Agency Lake stratum, increased by the same amount in the Tulana Open Water stratum, and rapidly increased in the Tulana Submergent stratum. After that, catch rates were variable in the Tulana Submergent stratum, consistent in the Tulana Open Water stratum, and decreasing in the Agency Lake stratum. When averaged over the entire time age-0 suckers were present in our samples, catch rates for this age class were highest in less than $2 \mathrm{~m}$ of water and lower in deeper water (fig. 12).

Standard lengths for age- 0 juvenile suckers in our catches are presented by week and strata in figure 13. The first age-0 Lost River sucker we caught during the week of June 22 was $45 \mathrm{~mm}$ SL and the first age- 0 shortnose sucker we caught during the week of July 6 was $36 \mathrm{~mm}$ SL. By the last week of sampling (September 21), the mean ( \pm SE) standard length for sacrificed suckers of both species was 63 $( \pm 2.7) \mathrm{mm}$. Regression lines of length over time for captured suckers and regression formulas are given in figure 14. Fit statistics $\left(\mathrm{R}^{2}\right)$ suggest the relationship between length and date was weak. Juvenile sucker length could be affected by hatch date, diet, movement, and growth.

External examination of age-0 suckers indicated deformities, macroparasites, and overt signs of illness or injury were uncommon. Only 20 (6.7 percent) were noted to have deformed opercles. Of these fish, five were Lost River suckers, three were shortnose suckers, and one was a sucker with characteristics intermediate to the three Lake suckers discussed in this report. The rest were not sacrificed, and therefore not identified to species. Nine age-0 suckers (3.0 percent) were noted to have one anchorworm Lernaea spp. each. Of these fish, two were Lost River suckers, one was a shortnose sucker, one was a sucker with characteristics intermediate to the three suckers discussed in this report, and the rest were not identified to species. Three also were noted to have red lesions that may have been caused by net abrasion.

\section{Age-1 and Age-2 Juvenile Suckers}

Despite low catch rates throughout the sampling season, we detected patterns in catch rates of age- 1 suckers that varied over space and time. Our first detection of an age-1 sucker occurred in the Tulana Open Water stratum the week of May 11 (fig. 15). Excluding that capture, greater catch rates shifted from the shallow eastern side to the deeper western side of the delta between the weeks of June 1 and July 20. During this time period, weekly mean ( \pm SE) catch rates varied between zero and $0.18 \pm$ 0.10 fish per net set (fig. 16). We recorded our last age-1 sucker capture for 2008 on July 22. When averaged over the time period that age-1 suckers were present in our catches, deeper sites had higher catch rates and a greater portion of sites with at least one age-1 sucker detection (fig. 12). However, low sample effort at sites with water depths greater than $4 \mathrm{~m}$ on the western side of the Tulana Unit limited our ability to determine how important deeper water habitats are for this age class of suckers. 
Age-1 suckers identified in our catches were between 75 and 133 mm SL. The first two age-1 suckers detected in our sampling were 91 and $96 \mathrm{~mm}$ SL (fig. 9). Mean age-1 sucker standard lengths ( \pm SE) were slightly greater in the Tulana Emergent stratum $(113.0 \pm 5.5 \mathrm{~mm}, \mathrm{n}=3)$, than in the Tulana Submergent (102.5 $\pm 4.5 \mathrm{~mm}, \mathrm{n}=11)$, Tulana Open Water $(104.4 \pm 2.2 \mathrm{~mm}, \mathrm{n}=23)$, or Agency Lake (108.2 $\pm 8.7 \mathrm{~mm}, \mathrm{n}=4$ ) strata (fig. 17).

Age-2 or older subadult suckers were much less common in our catches than age-1 suckers. We captured a total of three suckers that we judged to be at least 2 years old based on weekly length frequency distributions. All three of these captures occurred between July 2 and July 7 in $2.3-2.8 \mathrm{~m}$ of water. Two of these catches occurred in the Tulana Submergent stratum and the other occurred in Agency Lake. These three subadult suckers ranged from 176 to 190 mm SL (fig. 9).

External examination of age-1 and older juvenile suckers indicated deformities and macroparasites were uncommon. Only four age-1 suckers (9 percent) were noted to have deformed opercles. Five age-1 suckers (11 percent) and two age-2 suckers (66 percent) were noted to have one or more anchorworm Lernaea spp. attached. One age-1 sucker was noted to have a red lesion, which may have been caused by net abrasion.

We PIT tagged a total of four age-1 suckers between May 12 and June 16. After mid-June, we stopped tagging because increasing air and water temperatures appeared to cause undue stress on these fish. All four tagged suckers were held over night in a mesh net pen to assess initial tagging survival and tag retention. Three of the four suckers retained their tags and were judged to be in good health after the holding period, the fourth escaped during the night. No PIT tagged suckers from this or any other study were recaptured in our sampling.

\section{Juvenile Fish Community}

We captured a total of 12 non-sucker fish species in our trap net sampling between May 5 and September 28. Our catches were dominated by blue chub, fathead minnow, tui chub, and yellow perch (fig. 18). We also caught brown bullhead, slender sculpin Cottus tenuis, Klamath Lake sculpin Cottus princeps, Upper Klamath marbled sculpin Cottus klamathensis klamathensis, pumpkinseed Lepomis gibbosus, bluegill Lepomis macrochirus, largemouth bass Micropterus salmoides, and an undetermined species of lamprey Lampetra sp. Species richness ranged from 0 to 10 among sites and averaged (mean $\pm \mathrm{SE}$ ) $5.4 \pm 0.1$. The Shannon-Wiener Index of diversity ranged from 0 (only one species) to 1.75 and averaged (mean \pm SE) $0.93 \pm 0.01$, where a value of 2.48 represents identical numbers of all 12 species at a site.

Species richness, diversity, and composition varied somewhat by strata. All species were found in all four strata with the exception of largemouth bass. A single largemouth bass was detected at a site in the Tulana Submergent stratum. Mean species richness and diversity were highest at sites in Agency Lake followed by Tulana Open Water, Tulana Submergent, and Tulana Emergent strata (table 11). Fathead minnow were caught at higher rates in the Tulana Submergent and Tulana Open Water strata than in the Tulana Emergent and Agency Lake strata, whereas the opposite was true for blue chub (fig. 18). Catch rates for tui chub were slightly lower in the Tulana Emergent stratum than the other three areas. Yellow perch were caught at relatively high rates among all four strata. Brown bullhead catch rates were approximately an order of magnitude greater in the Tulana emergent and submergent strata than in the Tulana Open Water or Agency Lake strata. Sunfish, lamprey, and the three sculpin species combined made up only 0.06-5.7 percent of the catches in all four strata. 
There also were distinct temporal trends in the catch rates of the three most common species (blue chub, fathead minnow, and tui chub). For example, blue chub mean weekly catch rates peaked in the Tulana Submergent stratum the week of June 29 and in the Agency Lake stratum the week of September 21 (fig. 18). Mean weekly catch rates for both fathead minnows and tui chub were relatively low in both the Tulana emergent and submergent strata throughout most of the spring and early summer (fig. 18). Then between the weeks of August 24 and August 31 mean weekly tui chub catch rates doubled in the Tulana Submergent stratum. At the same time, there was a 10-fold increase in fathead minnow catch rates in the same stratum (fig. 18).

Of the piscivorous species large enough to prey on juvenile suckers we captured, yellow perch were the most abundant and widely distributed. The two other piscivorous species we detected, lamprey (243 fish) and largemouth bass (1 fish), were much less common. Based on length frequency histograms, it appeared that two cohorts of yellow perch were present in our catches. The older cohort, first caught the week of June 15 (fig. 19), ranged in length from 70 to $209 \mathrm{~mm}$ SL. The younger cohort was first detected the week of June 29 (fig. 19) and ranged in length from 26 to $69 \mathrm{~mm}$ SL. The ratio of younger to older cohorts in our samples was approximately two to one. Catch rates for older and larger yellow perch were consistently low in all strata, but catches of the younger and smaller fish were highest in the Tulana Open Water and Agency Lake strata.

An unexpectedly high number of nets set in the Williamson River Delta caught no fish (15) or contained all dead fish when retrieved (16). It was not part of our protocol to count and measure these catches of dead fish; instead, we made general notes about the location and dates of these incidents. Net sets that failed to catch any fish occurred in the Tulana Emergent stratum from June 26 to July 21 and in the Tulana Submergent stratum from July 10 to August 13. A week after several of our nets were pulled up empty, we began pulling up nets with dead and moribund fish. Fish in these nets included all of the species previously captured in the Williamson River Delta with the exception of suckers. Occasionally these nets contained several kilograms of dead and dying fish, but most often had only a few dozen dead or moribund fish. These high in-net-mortality incidents were nearly as common in the Tulana Submergent stratum (6) as in the Tulana Emergent stratum (7). Nets pulled with a higher number of dead or moribund juvenile fish occurred from July 1 to July 21 in the Tulana Emergent stratum. In the Tulana Submergent stratum, nets full of dead and moribund fish were recorded from July 17 to July 30 and again from September 8 to September 22. In addition, three nets set at one site in the Tulana Open Water stratum on July 30 contained a large number of dead fish when they were pulled.

\section{Health and Condition of Age-0 Juvenile Suckers}

\section{Mucosal Bacterial Communities}

Bacteria samples were obtained from 152 age-0 juvenile suckers collected from nine distinct areas in or adjacent to Upper Klamath Lake or from Clear Lake Reservoir over a 7-week period from late July through mid-September 2008 (table 12). In general, area-specific sample sizes were small with fewer than 10 fish sampled in some areas (table 12). The age-0 juvenile sampling effort resulted in the collection of Lost River, shortnose, and Klamath largescale suckers as well as some suckers that exhibited characteristics intermediate of all three species. Shortnose suckers dominated the collection (table 12). 
A total of 304 bacterial genera were identified from the fish collected in 2008. The molecular methods used in this study are very sensitive thus providing high levels of bacterial detection. These methods do not distinguish between actively growing, dormant, or dead bacteria. As long as DNA degradation has not occurred, the bacteria may be detected. The targeting of the bacterial 16S rRNA genes permits reliable identification to the genus level but not beyond.

Data filtering was necessary to increase the clarity of data presentation. The complete list of detected bacteria included genera that were only detected once. Detection of rare genera may result from incidental or accidental introductions. Events, like low-level introductions of non-indigenous bacteria into samples, are very difficult to avoid and can potentially alter the interpretation of unfiltered data sets. As additional data are acquired, the occurrence criteria used in this study will be modified and the list of genera will likely expand. The dataset presented here should be viewed only in terms of the presence of a given genera in the skin mucous.

Of those bacterial genera obtained from fish in or adjacent to Upper Klamath Lake, 20.4 percent were excluded for exceeding the primer to bacterial 16S rRNA genes mismatch criteria (table 2). Of the remaining genera, an additional 68.8 percent were excluded by low percent occurrence. The total number of genera obtained from the age- 0 juvenile suckers collected in Clear Lake Reservoir was reduced by 20.3 percent for primer mismatch with an additional 61.1 percent of the remaining genera excluded based on percent occurrence less than 50 percent.

Taxonomic nomenclature used in this report for the Acidobacteria and Cyanobacteria may be unfamiliar to some readers and some genera are conspicuously absent. Example genera that occur in the Cyanobacteria genus groups (Gp) included in this report are provided (table14). A. flos-aquae occur in Cyanobacteria Family I Gp I. This group was among those groups of Cyanobacteria detected in Upper Klamath Lake. A. flos-aquae was not identified in any of the 2008 samples. Amplification, however, of the $A$. flos-aquae 16S rRNA gene with the primers used in this study would require a minimum of three base mismatches. Examples comparable to those provided for the Cyanobacteria are not available for the Acidobacteria.

Many genera from the Enterobacteriaceae were identified but the genus Escherichia is not among them. Extensive sequencing of bacterial 16S rRNA genes has resulted in a reassessment of bacterial phylogenetic relationships, which has in turn led to taxonomic changes. Consequently, some bacteria that matched the phenotypic characteristics of Escherichia have been placed in other genera. A comparison of PAT results generated in this study with the taxonomic updates obtained for these results from the RDP showed that the bacteria previously identified as Escherichia were either left in this genus $(n=1)$ or placed in the genus Shigella $(n=21)$. The percent occurrence selection process for the 2008 samples was weighted toward genera obtained from fish collected in the Tulana area and the northern region of Upper Klamath Lake. These sites provided most of the age-0 juvenile suckers used for this analysis.

Age-0 juvenile sucker skin mucous bacteria data were summarized for all suckers sampled (figs. 20 to 23) and for age-0 juvenile shortnose suckers only (figs. 24 and 25). The shortnose sucker data were summarized separately because of their relative abundance in the dataset. The data are organized by sampling area with data from the Tulana unit of the Williamson River Delta and Agency Lake (figs. 20 and 25), Upper Klamath Lake proper (figs. 21 and 24), and Clear Lake Reservoir (fig. 22) presented as groups. Data from on- and off-shore samples obtained from the northern (fig. 22) and central (fig. 21) regions of Upper Klamath Lake also are presented. Data for all suckers sampled included fish from which no bacteria were detected. The shortnose sucker data excludes zero detection fish. 
Transforming Growth Factor-ß (TGF-ß) mRNA Expression

Tissue samples were obtained from 159 age-0 juvenile suckers collected in the areas and at the times described for bacterial sampling (table 15). Of the 159 samples, 102 were analyzed with 58 samples yielding usable measures of TGF-ß mRNA expression. Samples that were not analyzed included those that were obviously not spleen tissue, those that were in poor condition, or those that yielded insufficient quality mRNA for analysis. Analyzed samples that did not yield usable expression data failed to exhibit levels or TGF-ß and/or ß-actin mRNA expression above detection thresholds. Lost River and shortnose sucker TGF-ß expression data are provided (fig. 27). Observed TGF-ß to ß-actin mRNA expression ratios were within the range reported for other species of fish (Harms and others, 2000a, 2000b) and exhibited a degree of expression heterogeneity comparable to other species taken from the wild (Harms and others, 2000a).

\section{Discussion}

\section{Habitat Development in the Williamson River Delta}

In 2008, the newly flooded Tulana Unit of the Williamson River Delta was beginning to make the transition from upland agricultural fields to aquatic environments hospitable to suckers and other fish. Most of the delta was still vegetated with agricultural crops or upland vegetation in the early stages of decomposition. Wetland vegetation in the Tulana Emergent stratum was starting to become established, but other areas of the delta resembled adjacent lake habitats more than they did local wetlands (Wong and others, 2009). Nearly all species of fish commonly found in Upper Klamath Lake were collected in the inundated portion of the delta. Qualitative benthic grab samples indicated that food was available for juvenile suckers in the delta, but we were unable to establish the abundance of prey relative to the adjacent lake habitats due to time constraints. To quantify food resources in the delta and the northern portion of Upper Klamath Lake, we began collaborating with benthic invertebrate specialists from the USGS National Research Program in 2009.

In its first summer of re-establishment, the Williamson River Delta did not appear to host a large number of piscivorous fish. Largemouth bass, bluegill, pumpkinseed, and lamprey were rare throughout the delta. Fathead minnows, which can prey on larval suckers (Markle and Dunsmoor, 2007), were captured at lower rates in the Tulana Emergent stratum than other areas especially prior to August when larval suckers were most concentrated within the delta. Yellow perch were the most likely predatory threat to young suckers. The smaller (26-69 mm SL) members of this moderately piscivorous species (Keast, 1977), were found in the Tulana Emergent stratum as early as late June. Yellow perch potentially large enough (70-209 mm SL) to prey on very young juvenile suckers were much less common in the Tulana Emergent stratum, but somewhat common in the open water environments of the delta. The newly inundated areas did not appear to provide spawning habitat for this species given that none of their larvae were caught in our study and only a single yellow perch larvae was caught in the Tulana Unit in 2008 by TNC (H. Hendrixson, The Nature Conservancy, oral commun., 2009). 


\section{Larval Sucker Distribution}

Preliminary data suggest that environments in the Williamson River Delta, especially those in the Tulana Emergent stratum, provided high quality habitat for larval suckers. Sample densities in random stratified sampling for both Lost River sucker larvae and larvae identified as either shortnose or Klamath largescale suckers were an order of magnitude higher in the Tulana Emergent stratum than the Tulana Open Water or Agency Lake strata. Larval suckers caught in the delta were feeding and on average were larger than those caught in either Upper Klamath or Agency Lake. The only larvae to have empty digestive systems were Lost River suckers caught at the mouth of the Williamson River following a high flow event.

Some of the data presented here suggests that the timing of drift relative to the flow out of the Williamson River may influence the spatial distribution of larval suckers throughout the delta. Hydrodynamic models indicate that during high flow events proportionally more of the Williamson River flow is directed out the mouth rather than across the delta (T. Wood, U.S. Geological Survey, oral commun., 2008). Larval Lost River suckers drifted downstream earlier when the Williamson River discharge was relatively high (C. Ellsworth, U.S. Geological Survey, written commun., 2009) and primarily were captured at the mouth of the river. Cooperman and Markle (2003) noted a similar phenomenon in 1999 and 2000 when the earliest catches of larval suckers occurred lower in the Williamson River, coincident with seasonally high discharges. Larvae identified as shortnose and Klamath largescale suckers drifted later during lower river discharge (C. Ellsworth, U.S. Geological Survey, written commun., 2009), and primarily were captured in the Tulana Emergent stratum. Our hypotheses about larval sucker distributions relative to drift timing and river discharge remain in question, however, because our larval sucker catches in the Williamson River Delta were low, our sample efficacy was inconsistent, and we only have a single year of data to study. In addition to river discharge, a backwater effect caused by high lake-surface elevation also may affect the rate of transport out of the Williamson River and delta area (Cooperman and Markle, 2003). An alternative hypothesis is that larval suckers are adapted to rapid out-migration from the Williamson River regardless of hydrodynamic conditions (Cooperman and Markle, 2003). With the addition of habitat in the Goose Bay Unit and further years of data collection, we may be able to refine our understanding of how hydrodynamic conditions influence larval distribution.

During the initial year of this study, it became apparent that we could improve our larval data collection in two ways. First, developing a method to rapidly and positively identify larval suckers to species would allow us to begin to understand how endangered shortnose suckers are distributed differently than Klamath largescale suckers. This distinction may be important to understanding how varying life history strategies differentially affect the success of these two species. Geneticists from the USGS Western Fisheries Research Center are developing a rapid molecular identification technique for suckers which, given that they are successful, should be available for use on samples collected in 2009. Another improvement might be the use of lapilli otoliths for estimating daily ages of larval suckers (Hoff and others, 1997). We plan to implement this technique on larval suckers captured in 2009.

Repeated sampling at 30 sites indicated our plankton net sampling efficiency was inconsistent. Because catch rates did not decrease with each consecutive net tow, we believe that variable catch rates suggest larvae had a clumped distribution and does not indicate that replicate net tows depleted larvae at each site. These data should only be used to describe dominant distributional patterns and are not appropriate for extrapolating to estimate abundance. Given the high amount of variability in our sampling efficacy, we increased the number of random stratified sample sites selected in 2009. 


\section{Juvenile Sucker Distribution}

Distributional patterns for three cohorts of juvenile suckers throughout the Tulana Unit of the Williamson River Delta followed habitat use trends similar to those observed for these species in other parts of Upper Klamath Lake. Within Upper Klamath Lake, age-0 suckers are known to use shallow (less than $3 \mathrm{~m}$ ) (Buettner and Scoppettone, 1990; Terwilliger and others, 2004; Hendrixson and others, 2007; Burdick and others, 2009), sometimes vegetated water (Hendrixson and others, 2007; Burdick and others 2008), and are otherwise habitat generalists (Burdick and others, 2008). Age-0 juvenile sucker distribution in the Williamson River Delta followed a similar pattern; they primarily used sites less than $2 \mathrm{~m}$ deep until these habitats became unavailable as the lake elevation decreased. Age-1 suckers, which are known to use the deeper parts of Upper Klamath Lake (4 to $5 \mathrm{~m}$ ), especially in June (Burdick and others, 2008), were caught most frequently within the Williamson River Delta at sites 3-6 $\mathrm{m}$ deep. This older age class, however, also was detected in the shallower vegetated Tulana Emergent stratum as late as the week of June 29.

Spatial-temporal changes in juvenile sucker distribution coincided with shifts in dissolvedoxygen concentrations in the restored delta. During a 24 day period from mid-July to the end of August, median daily dissolved-oxygen concentrations in the Tulana Submergent stratum decreased to and stayed below $4 \mathrm{mg} / \mathrm{L}$ (Wong and others, 2009), an identified high stress threshold for juvenile suckers (Loftus, 2001). During this period, dissolved-oxygen concentrations occasionally decreased as low as 1 $\mathrm{mg} / \mathrm{L}$ during at least one hourly measurement in all parts of the delta except the Tulana Open Water stratum (Wong and others, 2009). Median daily DO concentrations for this period in the Tulana Submergent stratum were $3.6 \mathrm{mg} / \mathrm{L}$ lower than in the Tulana Open Water stratum and $5.1 \mathrm{mg} / \mathrm{L}$ lower than in Upper Klamath Lake (Wong and others, 2009). Although Agency Lake experienced a short-term decrease in dissolved oxygen in late July, it was less severe and of a shorter duration than in the delta (Wong and others, 2009). No age-1 suckers were caught in the Tulana Emergent and Tulana Submergent strata during this period of low dissolved oxygen. Age-1 sucker catch rates were low in the Tulana Open Water and Agency Lake strata the weeks of July 13 and July 20 before they went to zero at all locations in our study area. Age-0 sucker catches were very low in the Tulana Submergent stratum, but slowly increased in the Tulana Open Water stratum until mid- to late August. Age-0 catch rates decreased rapidly in Agency Lake in late August and simultaneously increased rapidly in the delta. Dissolved-oxygen concentrations increased in the delta at this time, suggesting this age class may have moved back into the delta as it became suitable to do so.

Poor July water quality in the Williamson River Delta also may explain the timing and location of nets that contained only dead and moribund fish. These incidents primarily occurred in July in the shallowest parts of the delta when and where dissolved-oxygen concentrations were lowest (Wong and others, 2009). During July, dissolved-oxygen concentrations followed a strong diel pattern that was most pronounced in our Tulana Emergent and Tulana Submergent strata. These concentrations averaged between 4 and $6 \mathrm{mg} / \mathrm{L}$ in the late afternoon and early evening and decreased to an average of less than 2 $\mathrm{mg} / \mathrm{L}$ in the early morning (Wong and others, 2009). Given that our nets were set in still water, we assume that fish entered them on their own initiative when water-quality conditions were survivable. Then, because they were trapped in our gear, these fish were unable to escape when dissolved-oxygen concentrations decreased to their lowest point early in the morning (Wong and others, 2009). Our experience with high juvenile fish mortality in several of our nets need not raise concerns about the effect of fluctuating DO concentrations in the delta on overall survival because uncaptured fish may survive by temporarily emigrating from poor water quality environments. 


\section{Hypothesized Gradient in Mucosal Bacterial Communities}

The current bacterial data set is too small to afford any statistical analysis. Data from 2009 and beyond will progressively improve future interpretative results. There is, however, a tentative hypothesis that can be put forward based on the 2008 data set. A casual viewing of the data suggests a north to south bacterial gradient in Upper Klamath Lake. Portions of the age- 0 juvenile sucker skin mucous bacterial flora present on fish collected in the northern region of the lake are totally absent from the fish collected in the south (figs. 22 and 24). This observation is most evident with the Cyanobacteria and Enterobacteriaceae, which were relatively abundant in the northern region, less abundant in the central, and totally absent from the suckers collected in the southern region of Upper Klamath Lake (figs. 22 and 24). If this hypothesis were to gain strength, it could have a substantial impact on how age0 juvenile sucker habitat quality is viewed within Upper Klamath Lake. It could also provide insight on movements of juveniles between regions of the lake.

\section{Transforming Growth Factor-ß (TGF-ß) mRNA Expression}

Obtaining quality spleen samples from these suckers proved to be problematic for some of the field crews charged with sample collection. For this reason, both spleen and kidney will be targeted for the measure of TGF- $ß$ mRNA expression in samples collected in 2009. Based on what is known from other fish species, expression levels in kidney will likely be lower relative to that obtained from spleen (Harms and others, 2000a, 2000b), but this deficit should be offset by more reliable sample collection. Sampling protocol changes for 2009 should facilitate the visualization of potential habitat or species related differences in age-0 juvenile sucker stress levels.

\section{Acknowledgments}

We thank Matt Abel, Ryan Braham, Ernest Chen, Nathan Harris, Anna Willard, and Debra Williams for help with data collection and Dave Simon (Oregon State University), and Charlie Erdman (The Nature Conservancy) for help with sucker species identification. We also thank Greta Blackwood and Alta Scott for help with database development and management. Craig Ellsworth, Heather Hendrixson (The Nature Conservancy), David Hewitt, Douglas Markle (Oregon State University), and Tamara Wood (Oregon Water Science Center) helped with study design. This work was funded by the Bureau of Reclamation (Interagency Agreement 04AA204032) and the U.S. Geological Survey. 


\section{References Cited}

Anderson, G.O., Wilkens, A.X. , Burdick, S.M., and VanderKooi, S.P., 2009, Seasonal distribution and abundance of larval and juvenile Lost River and shortnose suckers in Hanks Marsh, Upper Klamath National Wildlife Refuge, Upper Klamath Lake, Oregon: 2007 Annual Report: U.S. Geological Survey Open-File Report 2009-1014, 36 p.

Aranishi, F., and Nakane, M., 1997, Epidermal proteinases in the European eel: Physiological Zoology, v. 70, p. 563-570.

Burdick, S.M., Hendrixson, H.A., and VanderKooi, S.P., 2008, Age-0 Lost River and shortnose sucker near-shore habitat use in Upper Klamath Lake, Oregon: a patch-occupancy approach: Transactions of the American Fisheries Society, v. 137, p. 417-430.

Burdick, S.M., VanderKooi, S.P., and Anderson, G.O., 2009, Spring and summer habitat use by endangered juvenile Lost River and shortnose suckers in Upper Klamath Lake, Oregon: 2007 Annual Report: U.S. Geological Survey Open-File Report 2009-1043, 56 p.

Burdick, S.M., Wilkens, A.X., and VanderKooi, S.P., 2007, Near-shore and off-shore habitat use by endangered, juvenile Lost River and shortnose suckers in Upper Klamath Lake, Oregon: 2006 Data Summary: U.S. Geological Survey Open-File Report 2007-1356, 30 p.

Bureau of Reclamation, 2002, Metric Digital Elevation Model of Upper Klamath Lake [digital raster data].

Buettner, M., and Scoppettone, M.M., 1990, Life history and status of Catostomids in Upper Klamath Lake, Oregon: Oregon Department of Fish and Wildlife, Klamath Tribe, and National Fisheries Research Center, Reno, Nevada.

Chabrillón, M., Rico, R.M., Balebona, M.C., and Morinigo, M.A., 2005, Adhesion to sole, Solea senegalensis Kaup, mucus of microorganisms isolated from farmed fish and their interaction with Photobacterium damselae subsp. piscicida: Journal of Fish Disease, v. 28, p. 229-237.

Cooperman, M.S., and Markle, D. F., 2003, Rapid out-migration of Lost River and shortnose sucker larvae from in-river spawning beds to in-lake rearing grounds: Transactions of the American Fisheries Society, v. 132, p. 1138-1153.

Cooperman, M.S., and Markle, D.F., 2004, Abundance, size, and feeding success of larval shortnose suckers and Lost River suckers from different habitats of the littoral zone of Upper Klamath Lake: Environmental Biology of Fishes, v. 71, p. 365-377.

David Evans and Associates, Inc., 2005, Final Williamson River Delta restoration environmental impact statement: Portland, OR.

Ellsworth, C.M., Luton, C.D., Tyler, T.J., VanderKooi, S.P., and Shivley, R.S., 2007, Spawning migration movements of Klamath large scale, Lost River, and shortnose suckers in the Williamson and Sprague Rivers, Oregon, prior to the removal of Chiloquin Dam:. 2005 Annual Report: U.S. Geological Survey, Klamath Falls, Oregon, 42 p.

Ellsworth, C.M., Tyler, T.J., VanderKooi, S.P., and Markle, D.F., 2009, Patterns of larval sucker emigration from the Sprague and Lower Williamson River, Oregon, prior to the removal of Chiloquin Dam—2006 annual report: U.S. Geological Survey Open-File Report 2009-1027, 32 p.

Erdman, C.S., and Hendrixson, H.A., 2009, Larval shortnose and Lost River sucker response to large scale wetland restoration of the north half of the Williamson River Delta Preserve, Oregon: The Nature Conservancy, Oregon.

Fletcher, T.C., and White, A., 1973, Lysozyme activity in plaice (Pleuronectes platessa): Experientia, v. 29, p. 1283-1285. 
Harms, C.A., Ottinger, C.A., Blazer, V. S., Densmore, C. L., Pieper, L. H., and Kennedy-Stoskopf, S., 2000a, Quantitative polymerase chain reaction for transforming growth factor-ß applied to a field study of fish health in Chesapeake Bay Tributaries: Environmental Health Perspectives, v. 108, p. 447-452.

Harms, C.A., Ottinger, C.A., and Kennedy-Stoskopf, S., 2000b, Correlation of transforming growth factor-ß (TGF- $§$ mRNA) expression with cellular immunoassays in triamcinolone-treated captive hybrid striped bass: Journal of Aquatic Animal Health, v. 12, p. 9-17.

Hendrixson, H.A., Herring, B.L., Burdick, S.M., and VanderKooi, S.P., 2007, Near-shore and off-shore habitat use by endangered, juvenile Lost River and shortnose suckers in Upper Klamath Lake, Oregon: Draft Annual Report 2004, Report of U.S. Geological Survey, Western Fisheries Research Center, Klamath Falls Field Station to Bureau of Reclamation, Mid-Pacific Region, Klamath Falls, Oregon.

Hendrixson, H.A., 2008, Non-native fish species and Lost River and shortnose suckers use of restoration and undisturbed wetlands at the Williamson River Delta: Final report of activities conducted in 2006 and 2007: Report of The Nature Conservancy to the U.S. Fish and Wildlife Service, Klamath Falls, Oregon.

Hoff, G.R., Logan, D.J., and Markle, D.F., 1997, Otolith morphology and increment validation in young Lost River and shortnose suckers: Transactions of the American Fisheries Society, v. 126, p. 488-494. Iger, Y., Balm, P.H.M., Jenner, H.A., and Bonga, S.E.W., 1995, Cortisol induces stress-related changes in the skin of rainbow trout (Oncorhynchus mykiss): General and Comparative Endocrinology, v. 97, p. 188-198.

Keast, A., 1977: Diet overlap and feeding relationships between the year classes in the yellow perch (Perca flavescens): Environmental Biology of Fishes, v. 2, no. 1, p. 53-70.

Kelso, W.E., and Rutherford, A., 1996, Collection, preservation, and identification of fish eggs and larvae in Murry, B.R. and Willis, D.W., eds., Fisheries Techniques, $2^{\text {nd }}$ edition: American Fisheries Society, Bethesda, MD.

Loftus, M.E., 2001, Assessment of potential water quality stress to fish: Report by R2 Resources Consultants to Bureau of Indian Affairs, Portland, Oregon.

Markle, D.F., and Clauson, K., 2006, Ontogenetic and habitat-related changed in diet of late larval and juvenile suckers (catostomidae) in Upper Klamath Lake, Oregon: Western North American Naturalist, v. 66, no. 4, p. 492-501.

Markle, D.F., and Dunsmoore, L., 2007, Effects of habitat volume and fathead minnow introduction on larval survival of two endangered sucker species in Upper Klamath Lake, Oregon: Transactions of the American Fisheries Society, v. 136, p. 567-579.

Markle, D.F., and Simon, D.C., 1993, Preliminary studies of systematics and juvenile ecology of Upper Klamath Lake Suckers: Final Report: Oregon State University, Corvalis, Oregon.

Markle, D.F., Cavalluzzi, M.R., and Simon, D.C., 2005, Morphology and taxonomy of Klamath Basin suckers (Catostomidae): Western North American Naturalist, v. 65, no. 4, p. 473-489.

Markle, D.F., Reithel, S.A., Crandal, J., Wood, T., Tyler, T., Terwilliger, M., and Simon, D.C., 2009, Larval fish transport and retention and the importance of location for juvenile fish recruitment in Upper Klamath Lake, Oregon: Transactions of the American Fisheries Society, v. 138, p. 328-347. McCune, B., and Grace, J.B., 2002, Analysis of Ecological Communities: MJM Software Design, Gleneden Beach, Oregon.

Mulligan T.J., and Mulligan, H.L., 2007, Habitat utilization of life history patterns of fishes in Upper Klamath Wildlife Refuge Marsh, Fourmile Creek and Odessa Creek, Oregon: Humboldt State University, Department of Fisheries Biology, Arcata, California. 
National Research Council, 2004, Endangered and threatened fishes in the Klamath River Basin: The National Academies Press, Washington, D.C.

Nolan, D.T., van der Salm, A.L., and Bonga, S.E.W., 2000, The host-parasite relationship between rainbow trout (Oncorhynchus mykiss) and the ectoparasite Argulus foliaceus (Crustacea: Branchiura): epithelial mucous cell response, cortisol and factors which may influence parasite establishment: Contributions to Zoology, v. 69, p. 57-63.

Park, I.Y., Park, C.B., Kim, M.S., and Kim, S.C., 1998, Parasin I, and antimicrobial peptide derived from histone H2A in the catfish, Parasilurus asotus: FEBS Letters, v. 43, p. 258-262.

Quiniou, S.M.A., Bigler, S., Clem, L.W., and Bly, J.E., 1998, Effects of water temperature on mucous cell distribution in channel catfish epidermis: a factor in winter saprolegniasis: Fish and Shellfish Immunology, v. 8, p. 1-11.

Remple, S., and Markle, D.F., 2005, Description and identification of larval and juvenile cyprinids (fathead minnow, tui chub, and blue chub) from Upper Klamath Lake, Oregon: California Fish and Game, v. 91, no. 2, p. 83-99.

Silphaduang, U., Colorni, A., Noga, E.J., 2006, Evidence for widespread distribution of piscidin antimicrobial peptides in teleost fish: Diseases of Aquatic Organisms, v. 72, p. 241-252.

Simon, D.C., and Markle, D.F., 2002, Ecology of Upper Klamath Lake shortnose and Lost River suckers: Annual survey of abundance and distribution of age-0 shortnose and Lost River suckers in Upper Klamath Lake. 2001 Annual Report. Report of Oregon Cooperative Research Unit, Department of Fisheries and Wildlife, Oregon State University to U.S. Biological Resources Division, U.S. Geological Survey, Corvallis, Oregon and Klamath Project, Bureau of Reclamation, Klamath Falls, Oregon.

Smith, C.J., Danilowicz , B.S., and Meijer, W.G., 2007, Characterization of the bacterial community associated with the surface and mucus layer of whiting (Merlangius merlangus): FEMS Microbiology Ecology, v. 62, p. 90-97.

Songrad, S.M., 1992, Variability in growth rates of juvenile fishes indifferent estuarine habitats: Marine Ecology Progress Series, v. 85, p. 35-53.

Sullivan, A.B., Deas, M.L., Asbill, J., Kirshtein J.D., Butler, K., Vaughn, J., 2009, Klamath River water quality data from Link River Dam to Keno Dam, Oregon, 2008, U.S. Geological Survey Open-File Report 2009-1105, 25 p.

Terwilliger, M.R., Simon, D.C., and Markle, D.F., 2004, Larval and juvenile ecology of Upper Klamath Lake suckers: 1998-2003-Final report: Report of Oregon State University to Bureau of Reclamation, Klamath Falls, Oregon.

The Nature Conservancy, 2009, Water quality conditions on the Williamson River Delta, Oregon: One year post-restoration: Report to the Bureau of Reclamation and the Oregon Watershed Enhancement Board Klamath Falls, Oregon.

U.S. Fish and Wildlife Service, 2005, Upper Klamath National Wildlife Refuge proposed addition: planning update: U.S. Fish and Wildlife Service, Klamath Falls, Oregon.

U.S. Geological Survey, 2009, National Water Information System Web Interface. http://waterdata.usgs.gov/nwis/nwisman/?site_no=11502500\&agency_cd=USGS. Accessed on August 11, 2009.

VanderKooi, S.P., Herring, B.L., Coshow, R.H., and Hendrixson, H.A., 2006, Near-shore habitat use by endangered juvenile suckers in Upper Klamath Lake, Oregon: Annual Report 2002-2003: U.S. Geological Survey, Western Fisheries Research Center, Klamath Falls Field Station, Klamath Falls, Oregon. 
van der Salm, A.L., Nolan, D.T., and Bonga, S.E.W., 2002, In vitro evidence that cortisol directly modulates stress-related responses in the skin epidermis of the rainbow trout (Oncorhynchus mykiss Walbaum): Fish Physiology and Biochemistry, v. 27, p. 9-18.

van der Salm, A.L., Nolan, D.T., Spanings, F.A.T., and Bonga, S.E.W., 2000, Effects of infection with the ectoparasite Argulus japonicus (Thiele) and the administration of corisol on cellular proliferation and apoptosis in the epidermis of common carp: Cyprinus carpio L., skin: Journal of Fish Diseases, v. 23, p. 173-184.

Westerdahl, A., Olsson, J.C., Kjelleberg, S., and Conway, P.L., 1991, Isolation and characterization of Turbot (Scophtalmus (sic) maximus) - associated bacteria with inhibitory effects against Vibria anguillarum: Applied Environmental Microbiology, v. 57, p. 2223-2228.

Wong, S., Doehring, C., and Hendrixson, H., 2009, Continuous physical water chemistry monitoring in water quality conditions on the Williamson River Delta, Oregon: One Year Post-Restoration: The Nature Conservancy, Klamath Basin Field Office, Klamath Falls, Oregon. 
This page left intentionally blank 


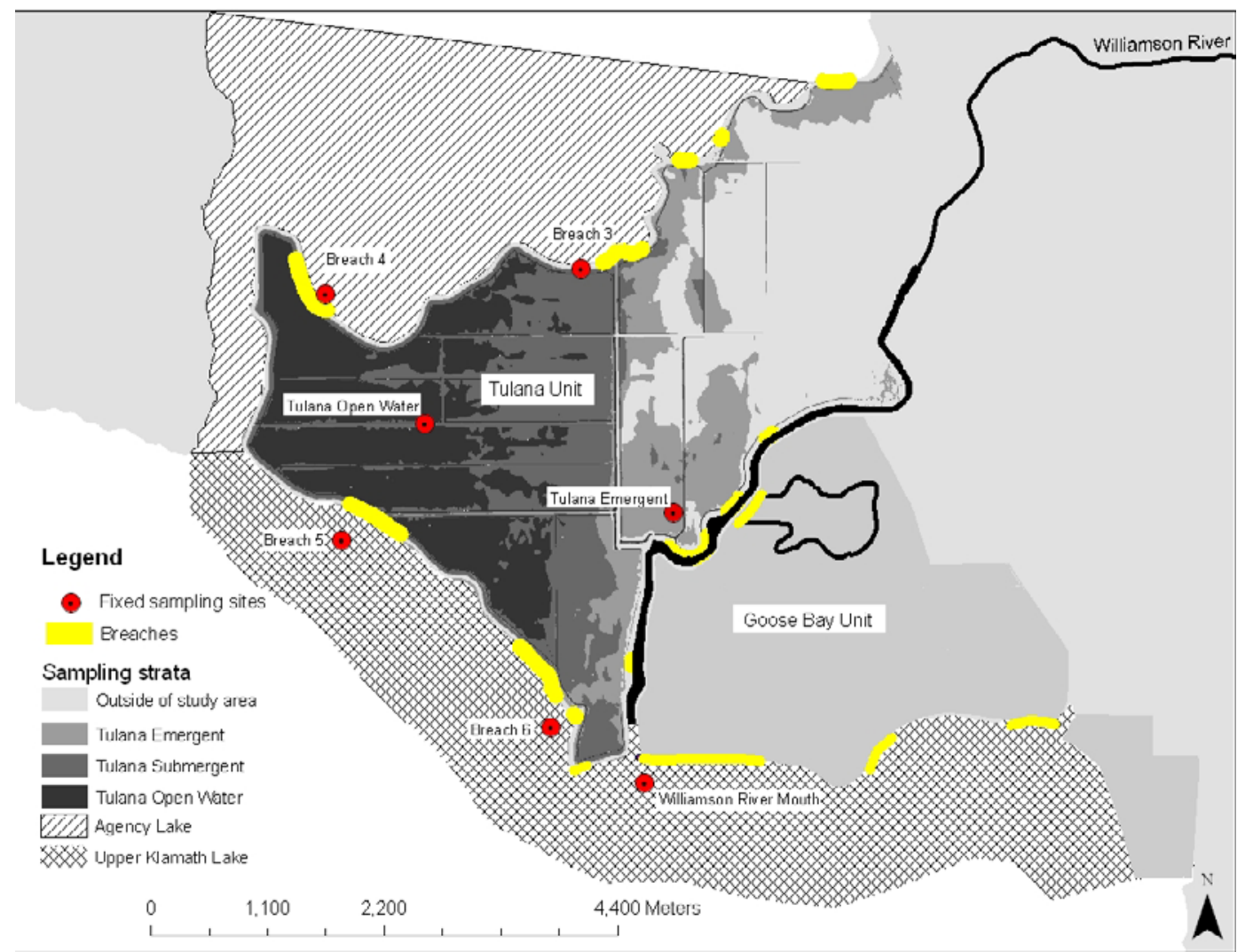

Figure 1 Map of study area in and adjacent to the Williamson River Delta, in the northeast portion of Upper Klamath Lake, Oregon (see fig. 2). The delta was inundated to recreate wetland and aquatic habitats for endangered Lost River and shortnose suckers, beginning with the northern Tulana Unit in October of $\mathbf{2 0 0 7}$ and the southern Goose Bay Unit in November 2008. Five sampling strata and fixed larval sampling sites are shown. Sampling strata within the delta were selected based on the type of aquatic plant communities predicted to colonize in these areas in a below average water year (David Evans and Associates Inc., 2005). 


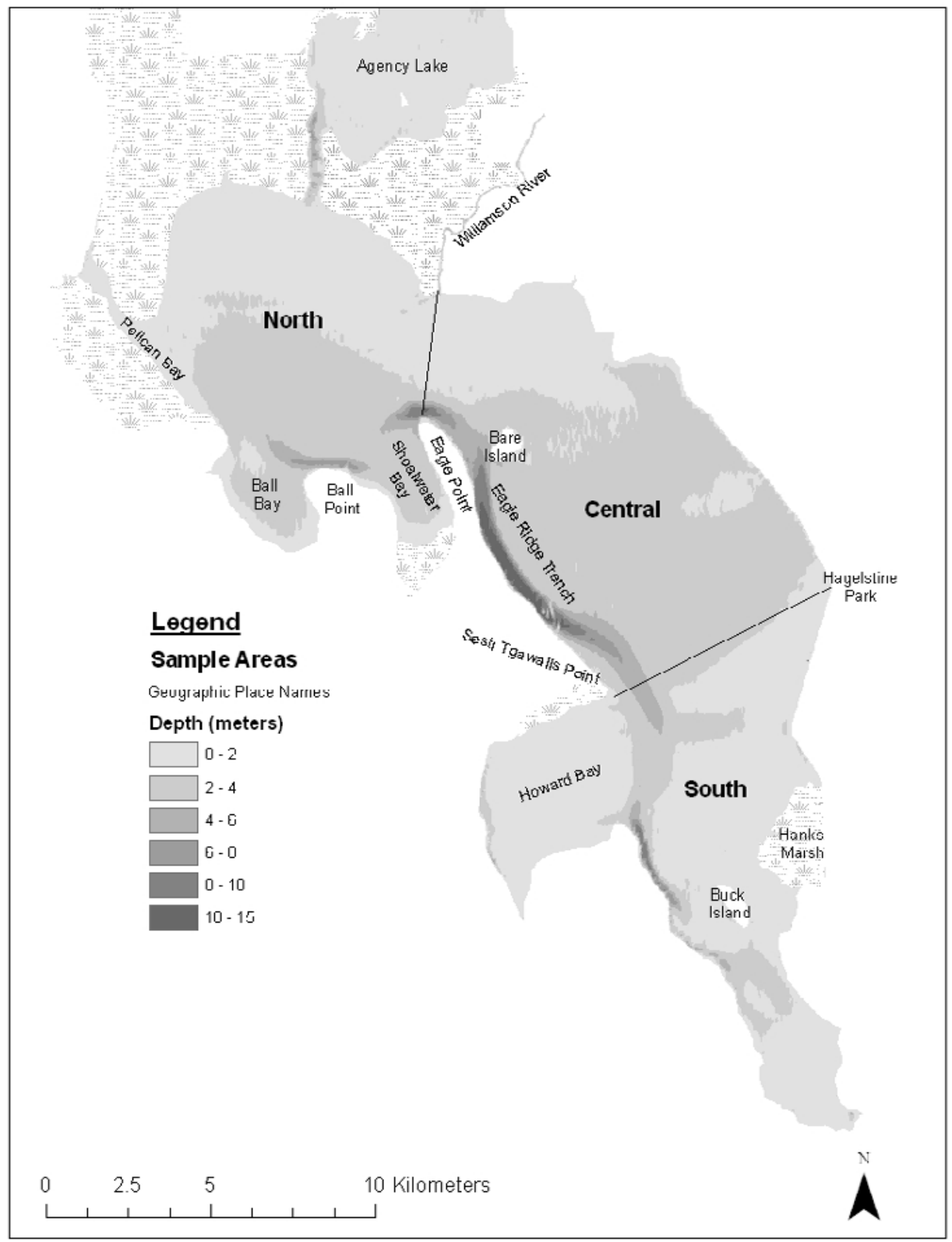

Figure 2. Map of Upper Klamath Lake study area and three defined areas of the lake. Near-shore strata were considered areas within 100 meters of shore, whereas off-shore strata are areas more than 100 meters from shore. The lake was stratified by area to provide good coverage of the entire lake. Bathometry layer is from Bureau of Reclamation (2002). 


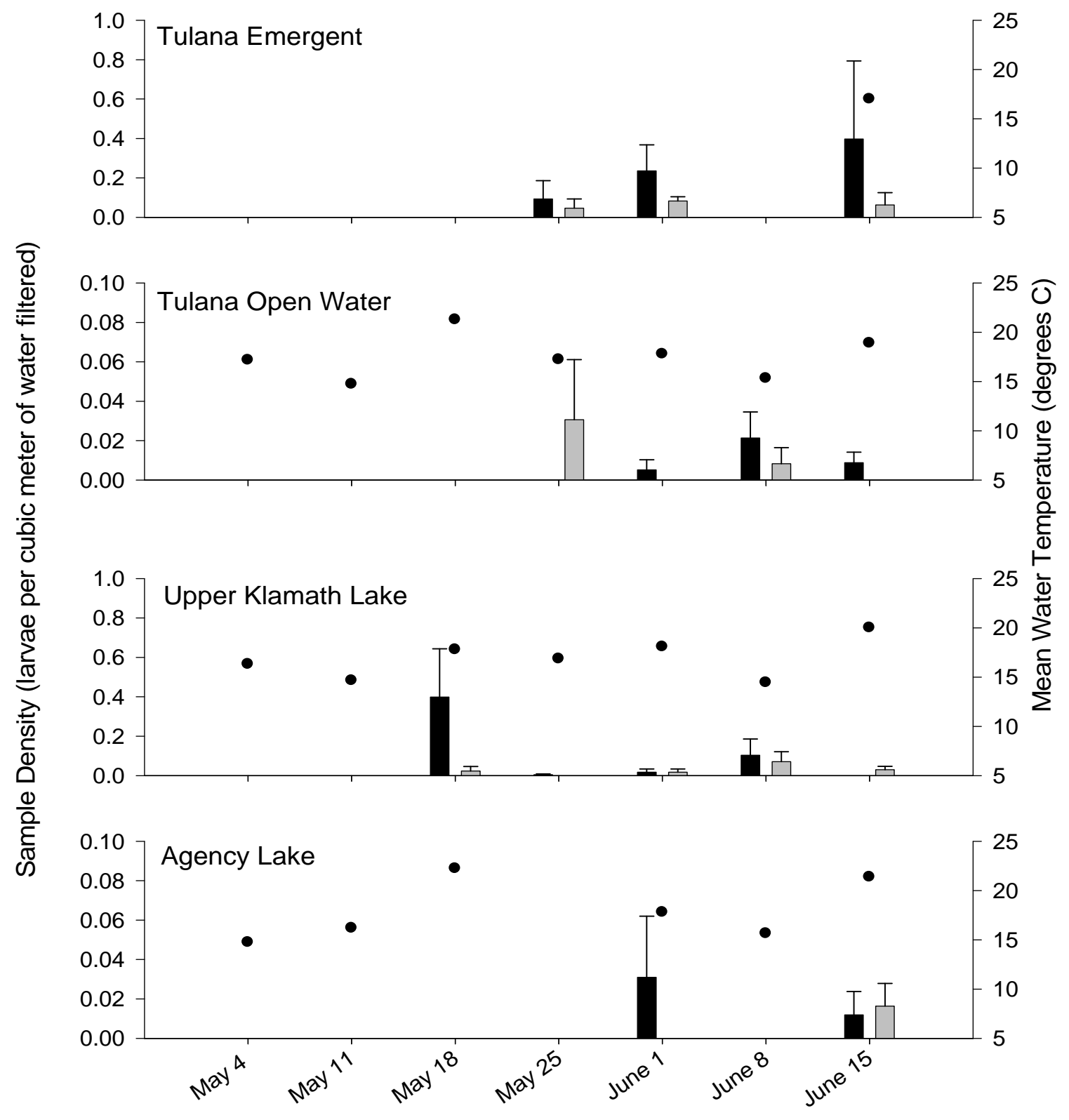

Figure 3. Mean ( \pm SE) weekly sample density for Lost River sucker larvae (black bars), and a grouping of larvae identified as either shortnose or Klamath largescale suckers (grey bars). Mean water temperature for larval tow sites is shown with black dots. Larvae were collected in plankton nets towed in four sample strata (see fig. 1) in and around the Williamson River Delta, Oregon, between May 5 and June 17, 2008. 


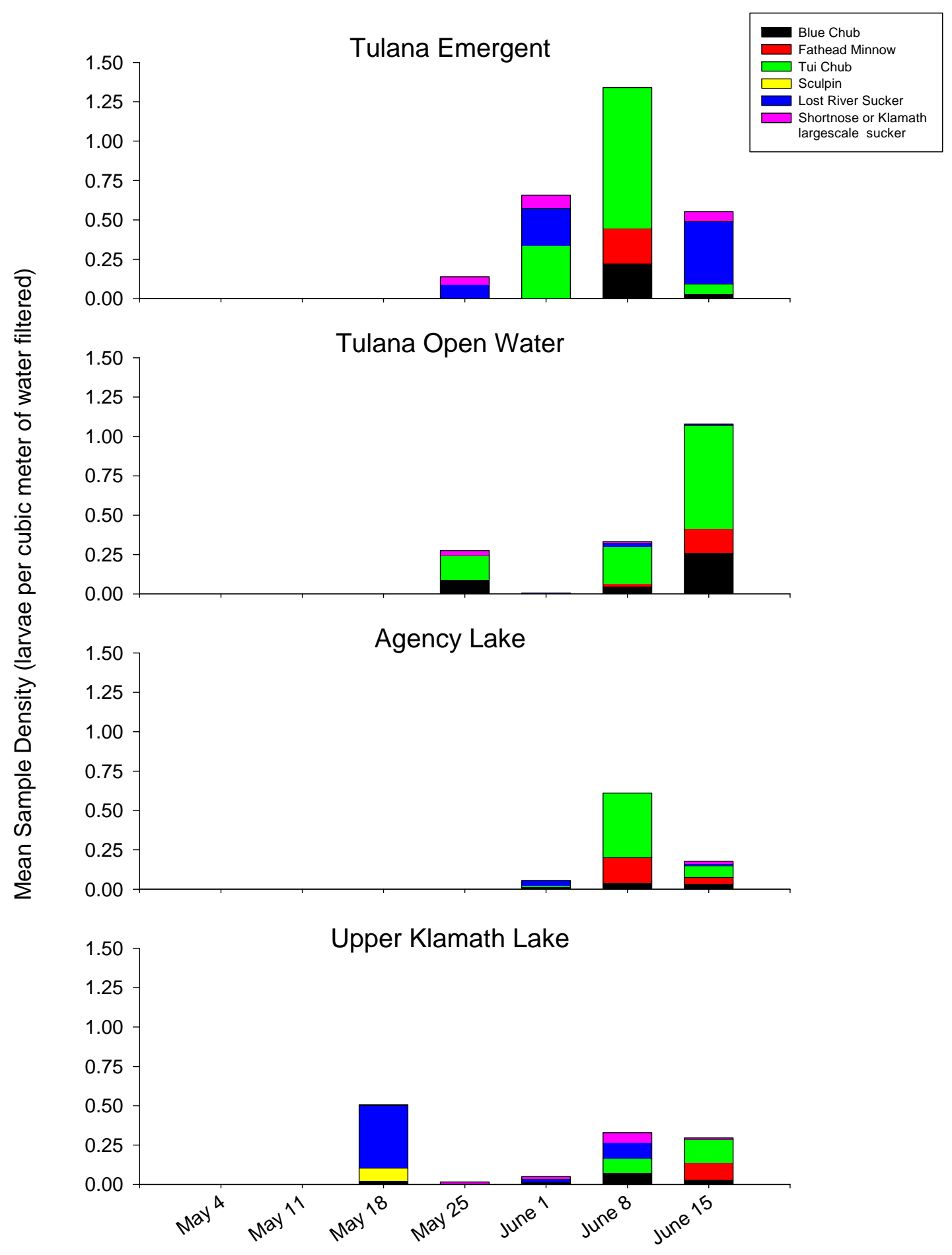

Figure 4. Mean weekly sample density of larval fish in plankton samples collected from four strata (fig. 1) in and adjacent to the Williamson River Delta, Oregon, between May 5 and June 17, 2008. 

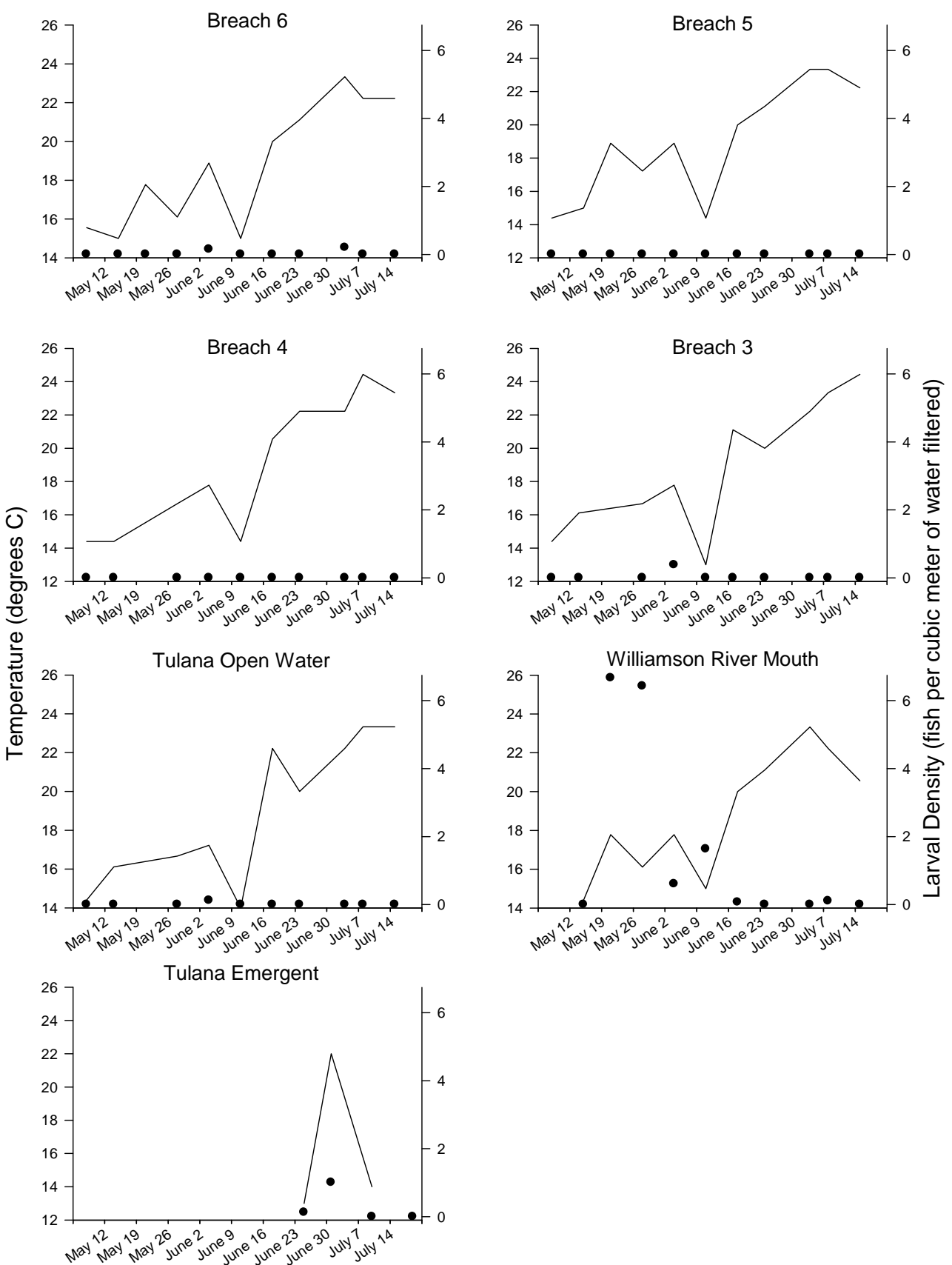

Figure 5. Larval Lost River sucker sample densities (black dots) at seven fixed sites sampled weekly in and adjacent to the Williamson River Delta, Oregon, between May 5 and July 18, 2008. Larvae were collected in plankton nets towed laterally to a boat at slow speeds. Solid lines indicate water temperatures recorded at the time of sampling. 

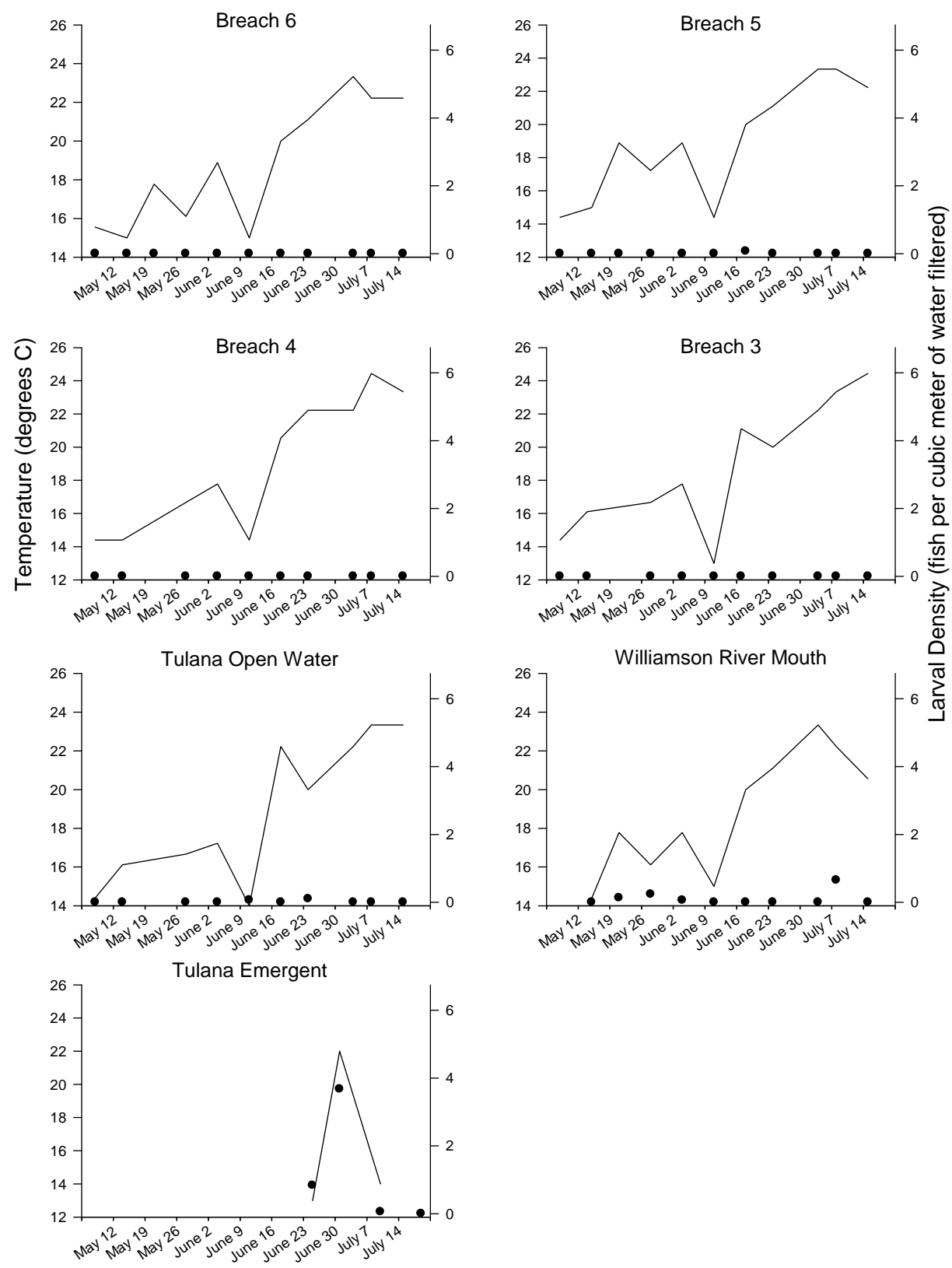

Figure 6. Larval shortnose or Klamath largescale sucker sample densities (black dots) at seven fixed sites sampled weekly in and adjacent to the Williamson River Delta, Oregon, between May 5 and July 18, 2008. These two species are morphologically similar and can not be distinguished to lower taxa as larvae; therefore, they were grouped together for this data summary. Larvae were collected in plankton nets towed laterally to a boat at slow speeds. Solid lines indicate water temperatures recorded at the time of sampling. 


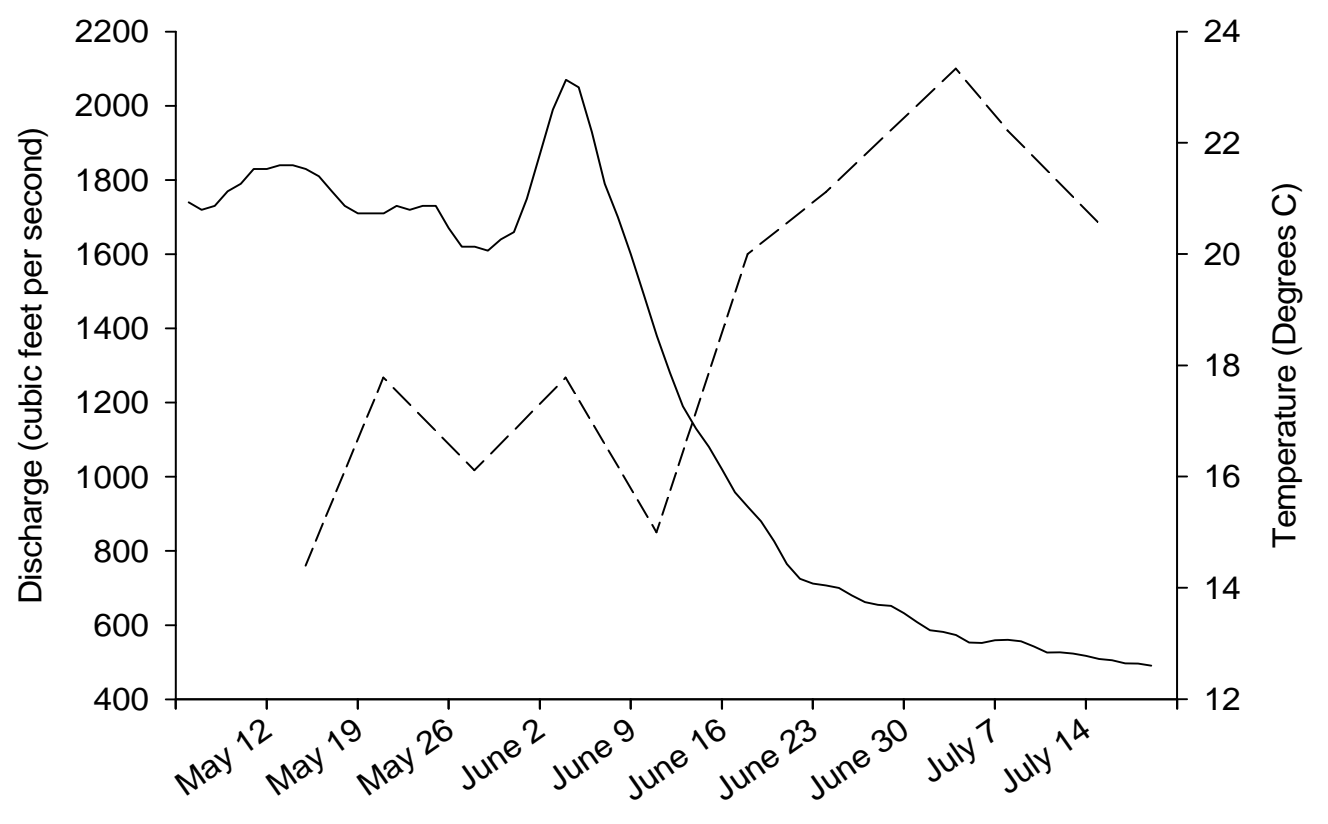

Figure 7. Williamson River discharge [cubic feet per second, solid line; U.S. Geological Survey, 2009; water gage number 11502500] and water temperature at the mouth of the Williamson River (dashed line), as measured during weekly site visits between May 5 and July 18, 2008. Seven sites were visited weekly to sample for larval fish. 


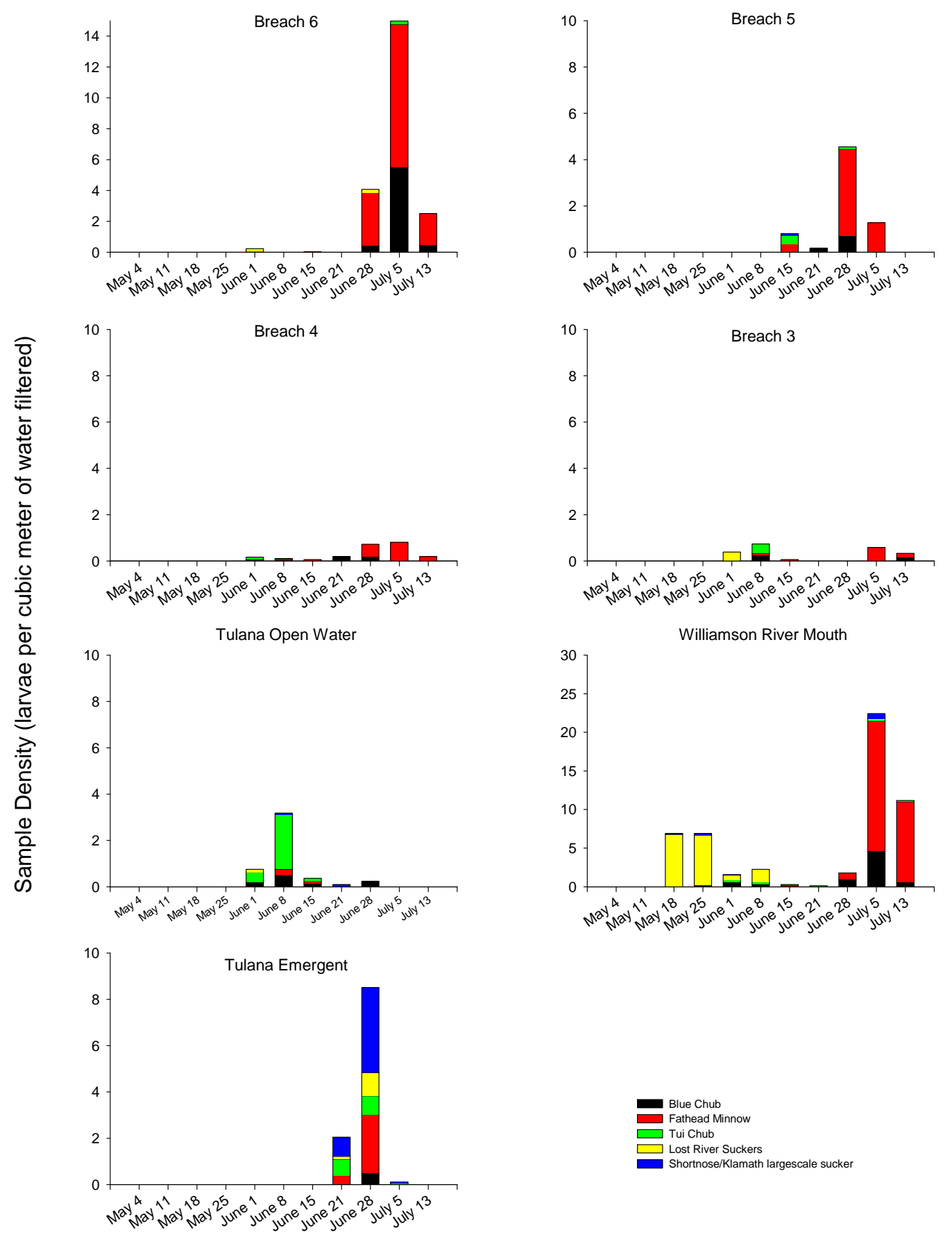

Figure 8. Larval sample density (larvae per cubic meter of water filtered) by week and species at seven fixed sites sampled weekly in and adjacent to the Williamson River Delta, Oregon, between May 5 and July 18, 2008. Notice the difference in scale along the y-axis at breach 6 and at the Williamson River mouth. 


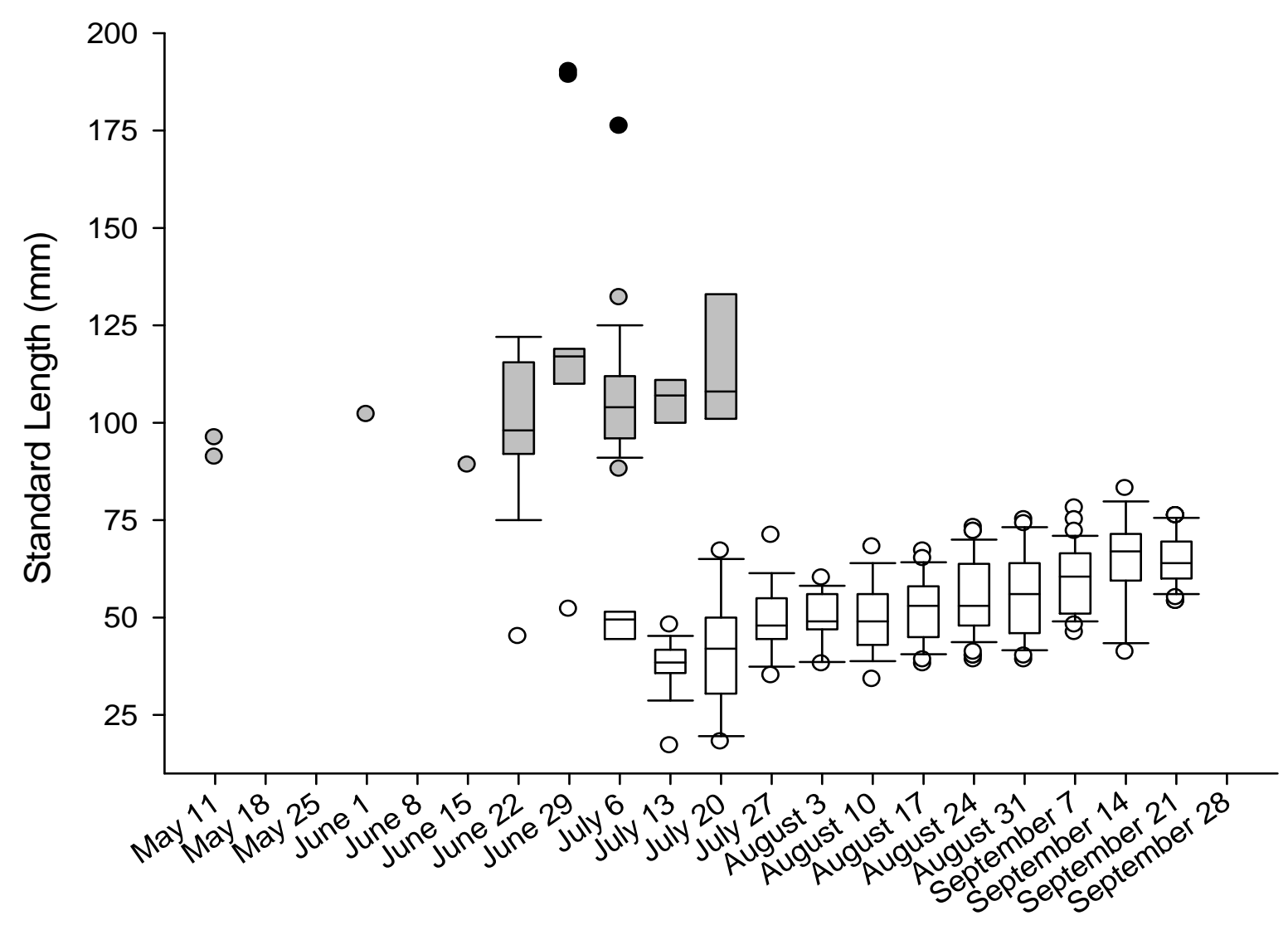

Figure 9. Length of juvenile suckers collected in trap nets set in the Williamson River Delta and southern Agency Lake, Oregon, between May 5 and September 25, 2008. Three age classes are shown, juvenile age- 0 suckers are shown in white, age-1 suckers in grey, and age-2 or older suckers are shown in black. Within each age class and each week, boxplots indicate the $25^{\text {th }}, 50^{\text {th }}$, and $75^{\text {th }}$ percentiles, the whiskers indicate $5^{\text {th }}$ and $95^{\text {th }}$ percentiles and circles indicate outliers. 


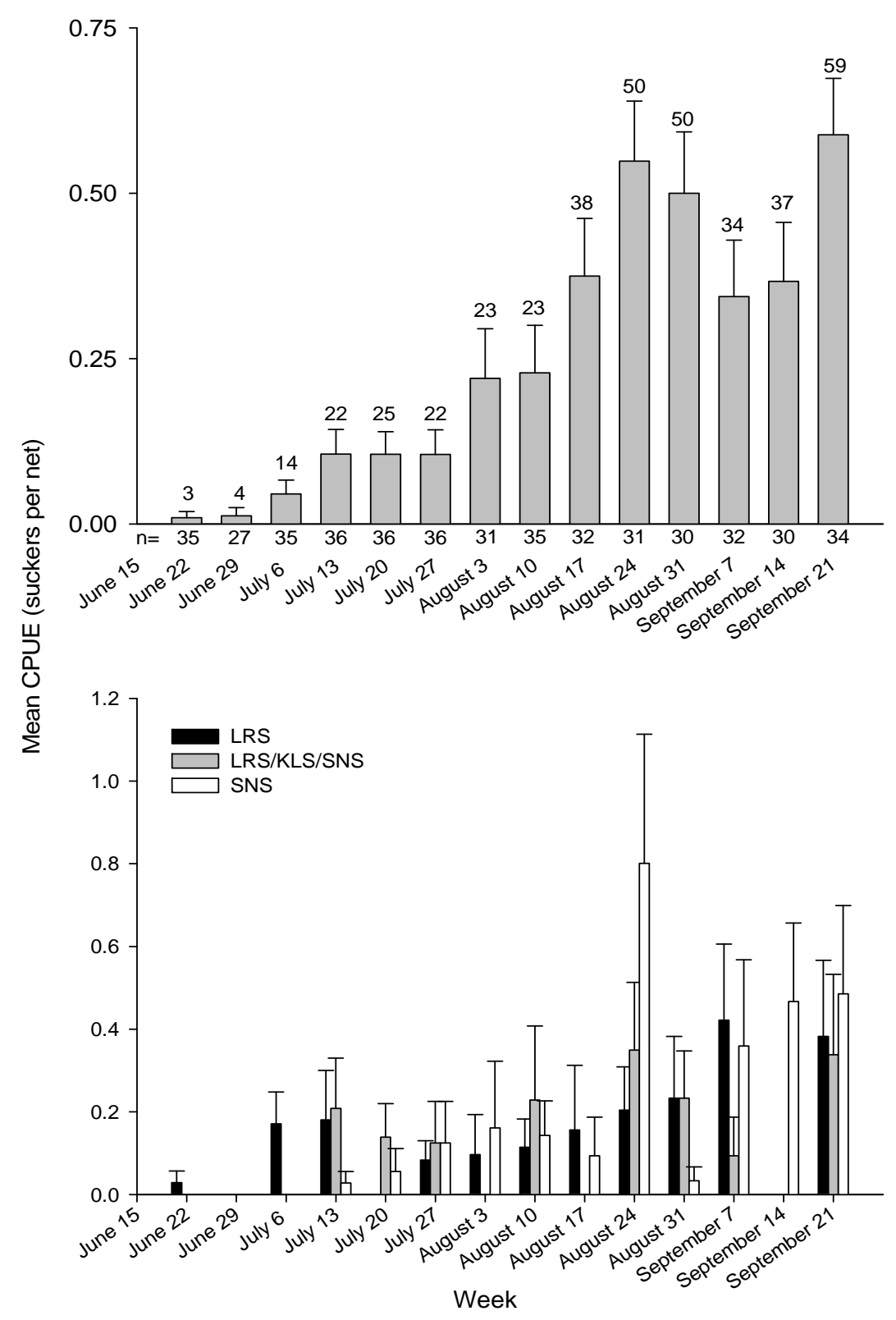

Figure 10. Mean ( \pm SE) weekly catch per unit effort (suckers per net) for age-0 suckers caught in trap nets set overnight in the Tulana Unit of the Williamson River Delta and Agency Lake (see fig. 1), between June 22 and September 26, 2008 (top). The percentage of sites at which at least one sucker was caught and the number of sites sampled each week are given above and below the $x$ axis, respectively. Mean ( \pm SE) weekly catch per unit effort for age-0 Lost River sucker (LRS, black), shortnose suckers (SNS, white), and suckers with characteristics of Lost River, shortnose or Klamath largescale suckers (LRS/SNS/KLS, grey) also are shown for the same time period (bottom). 

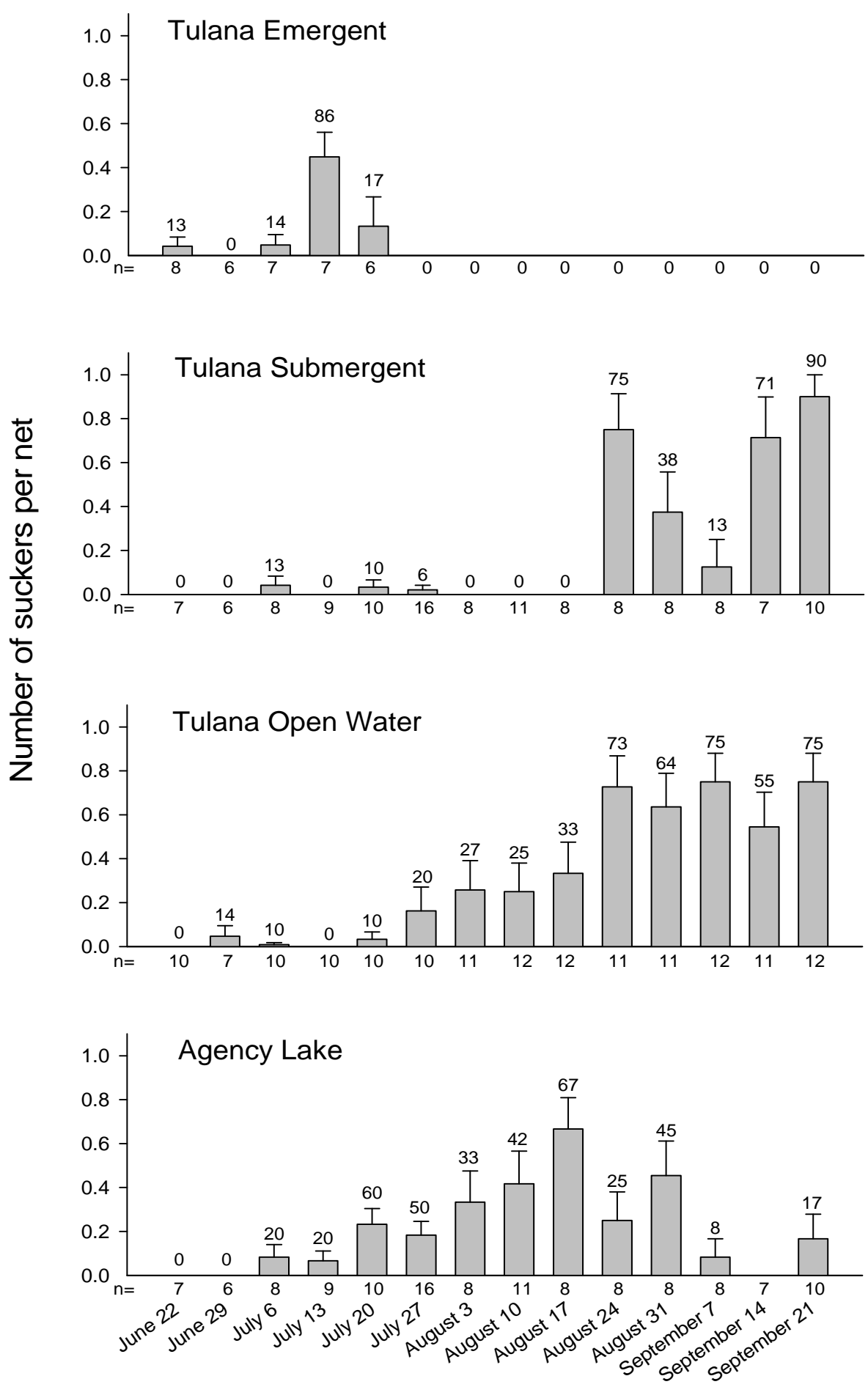

Figure 11 Mean $( \pm$ SE) weekly catch per unit effort (suckers per net) for age-0 suckers caught in three areas of the Tulana Unit of the Williamson River Delta and in southern Agency Lake, between June 22 and September 26, 2008. The percentages of sites at which least one sucker was caught and number of sites sampled are given above and below the $x$-axis, respectively. 


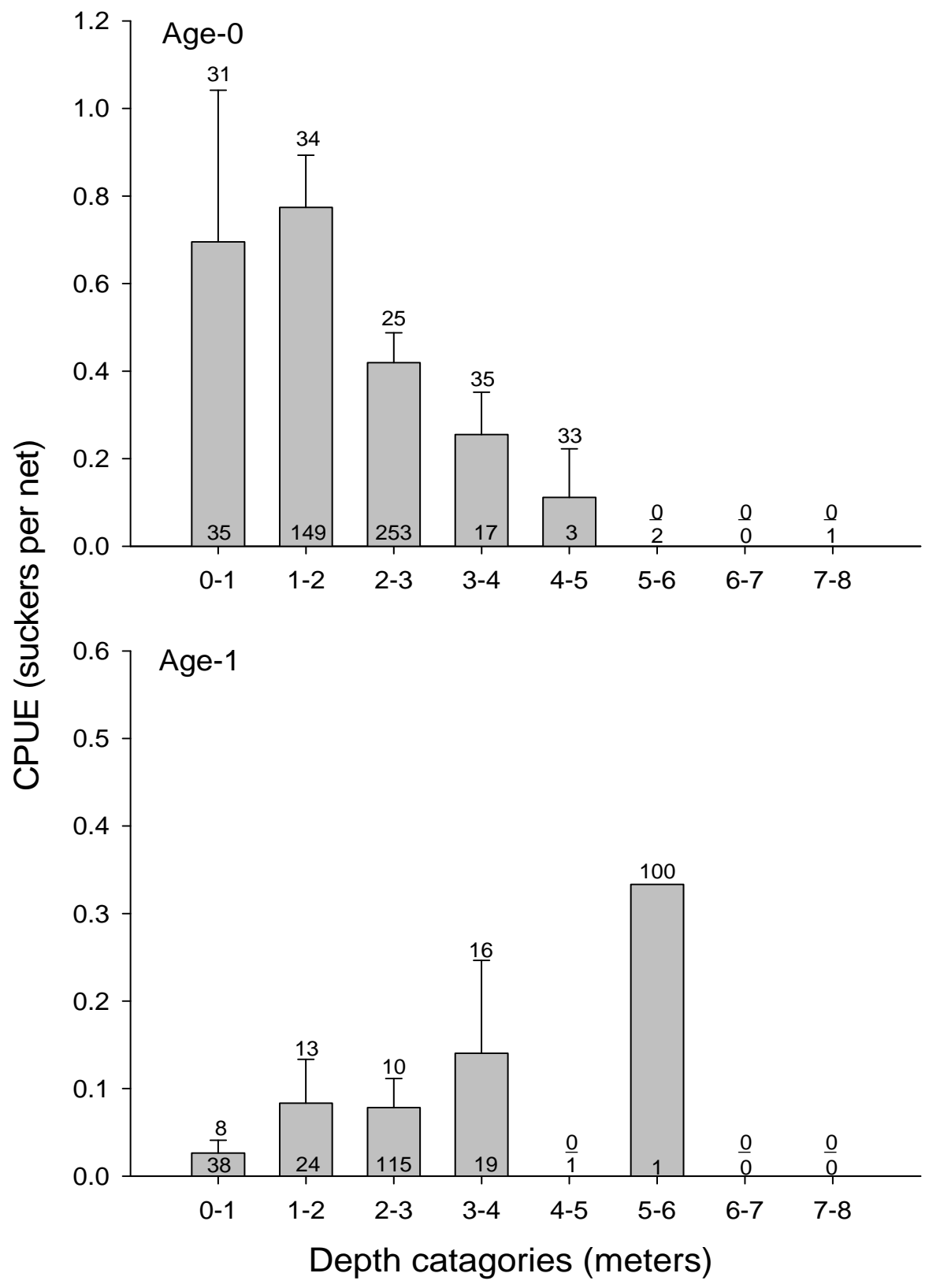

Figure 12. Mean $( \pm \mathrm{SE})$ catch per unit effort (CPUE: suckers per net) by 1-meter depth bins for age-0 (top) and age-1 (bottom) suckers caught in the Williamson River Delta and southern Agency Lake, Oregon. The percentages of sites in each depth category at which at least one sucker was caught are given (above the bars) and the number of sites sampled in each depth category (above the $x$-axis). The sample sites used in preparation of this figure were limited to those sampled between the first and last capture of suckers in each age group. Therefore, for age- 0 suckers only sites sampled between June 22 and September 21 were used, and for age-1 suckers only sites sampled between May 11 and July 20 were used. 

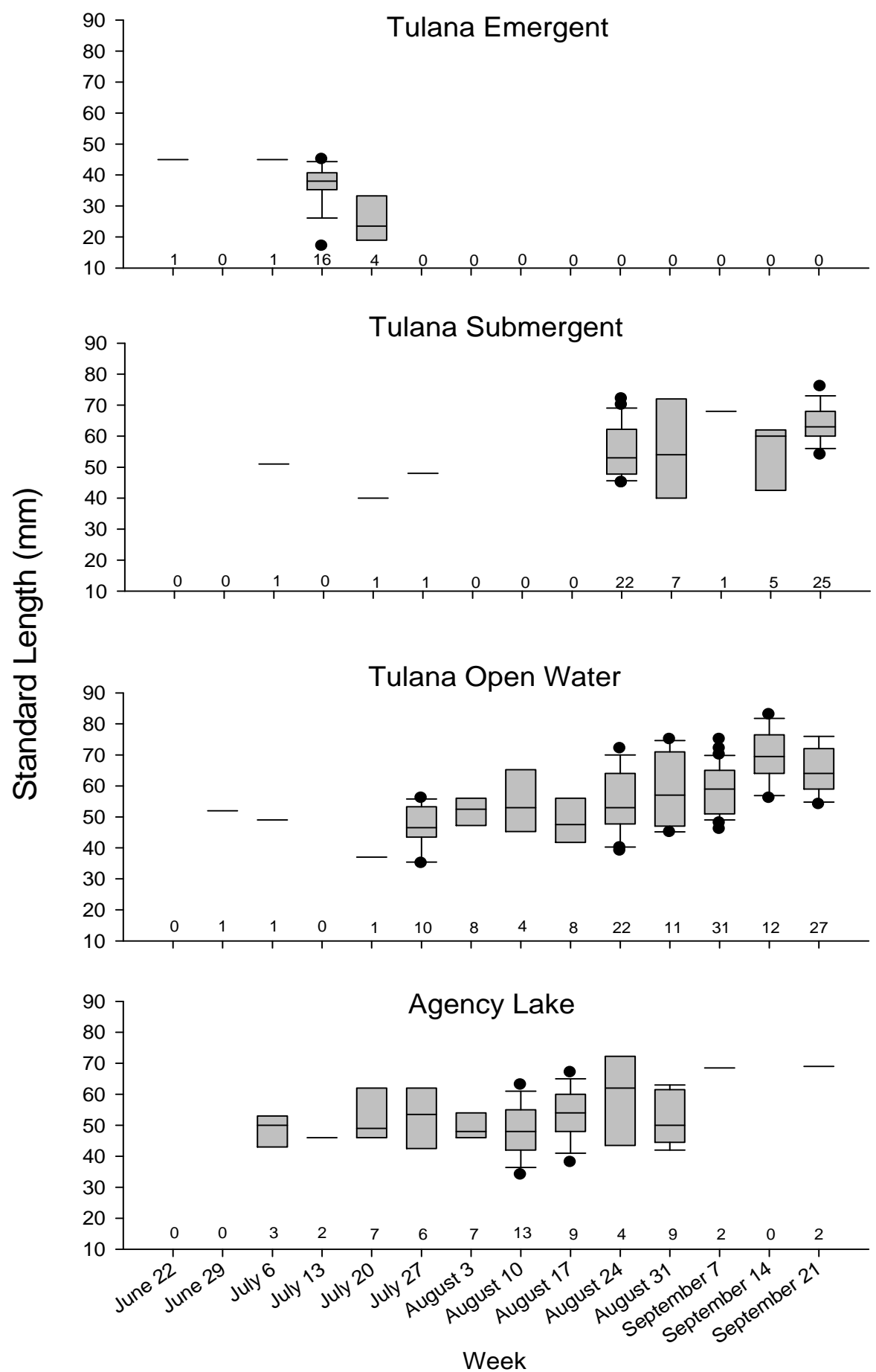

Figure 13. Standard length $(\mathrm{mm})$ of age-0 suckers caught in trap net sampling in three strata in the Tulana Unit of the Williamson River Delta and one stratum in southern Agency Lake, Oregon, between June 22 and September 25, 2008. The numbers of age-0 suckers caught each week in each stratum, and used in the creation of each boxplot are given along the $x$-axis. Boxplots indicate the $25^{\text {th }}, 50^{\text {th }}$, and $75^{\text {th }}$ percentiles, the whiskers indicate $5^{\text {th }}$ and $95^{\text {th }}$ percentiles and circles indicate outliers. 

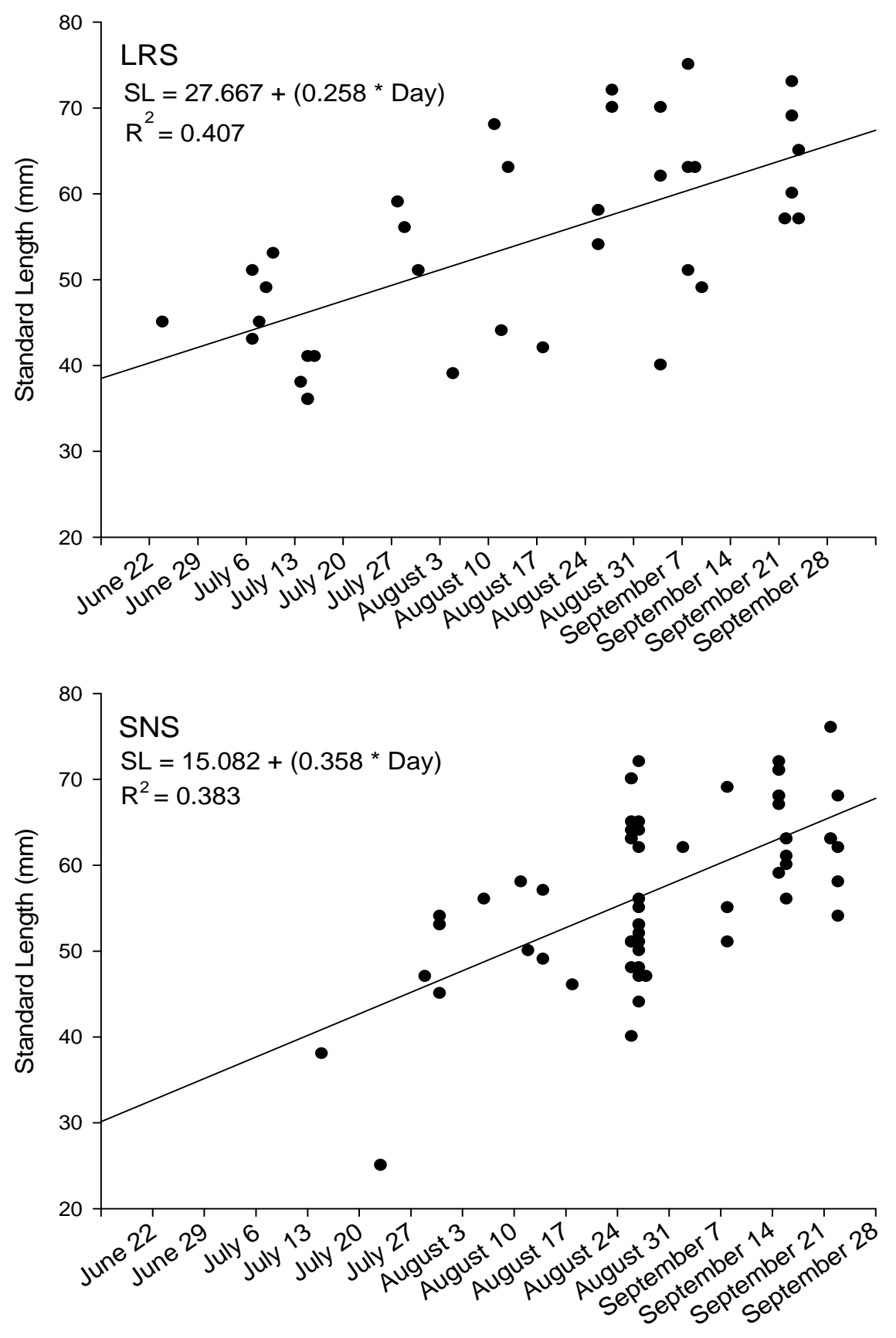

Figure 14. Standard lengths (SL) of sacrificed age-0 Lost River suckers (LRS; top) and shortnose suckers (SNS; bottom) are shown by date of capture. These fish were collected in or adjacent to the Williamson River Delta, Oregon, between June 22 and September 25, 2008. 

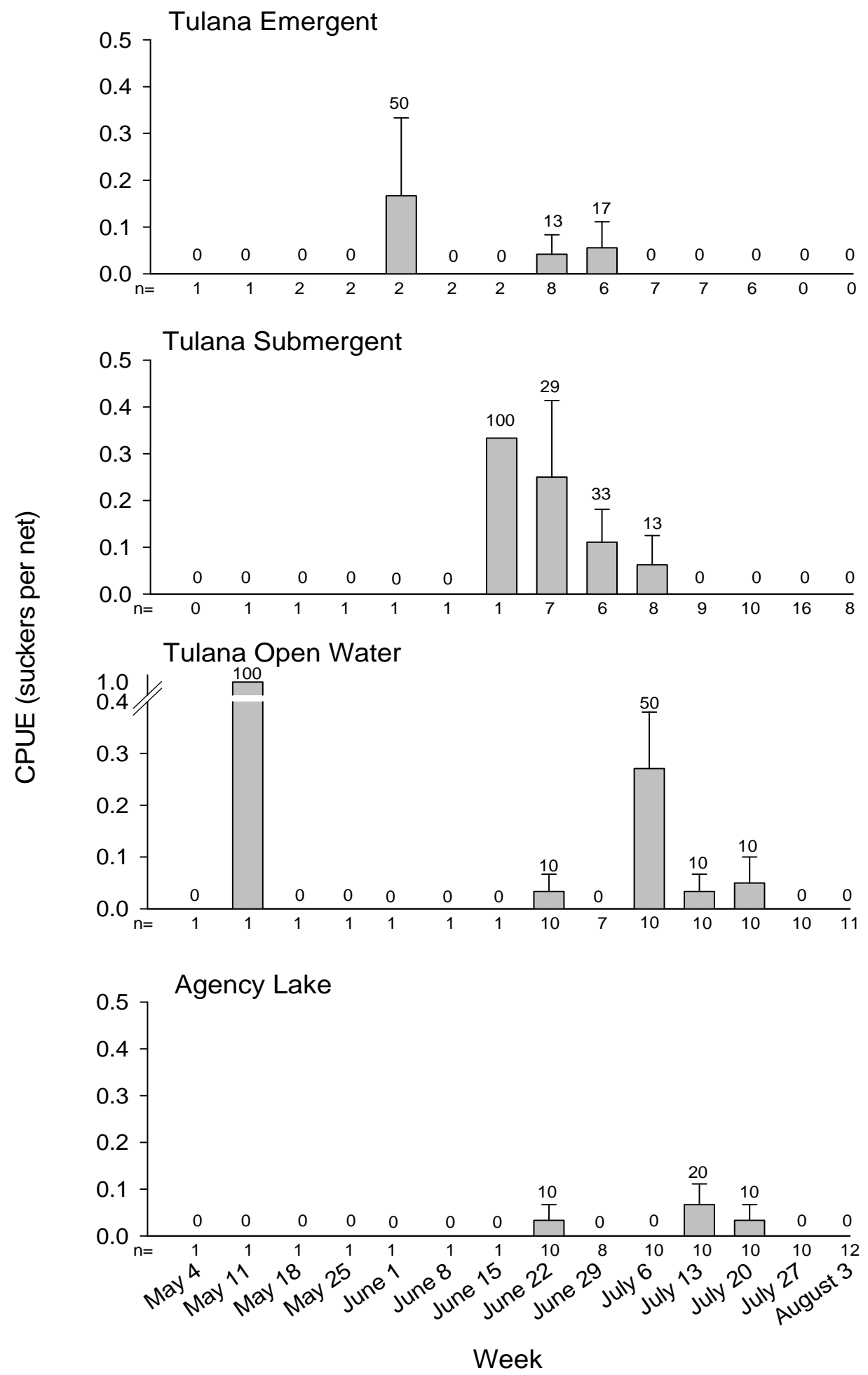

Figure 15. Mean ( \pm SE) weekly catch per unit effort (suckers per net) for age-1 suckers caught in three areas of the Tulana Unit of the Williamson River Delta and southern Agency Lake, Oregon, between May 5 and July 25,2008. The percentages of sites at which at least one age-1 sucker was caught and number of sites sampled are given above and below the $\mathrm{x}$-axis, respectively. 


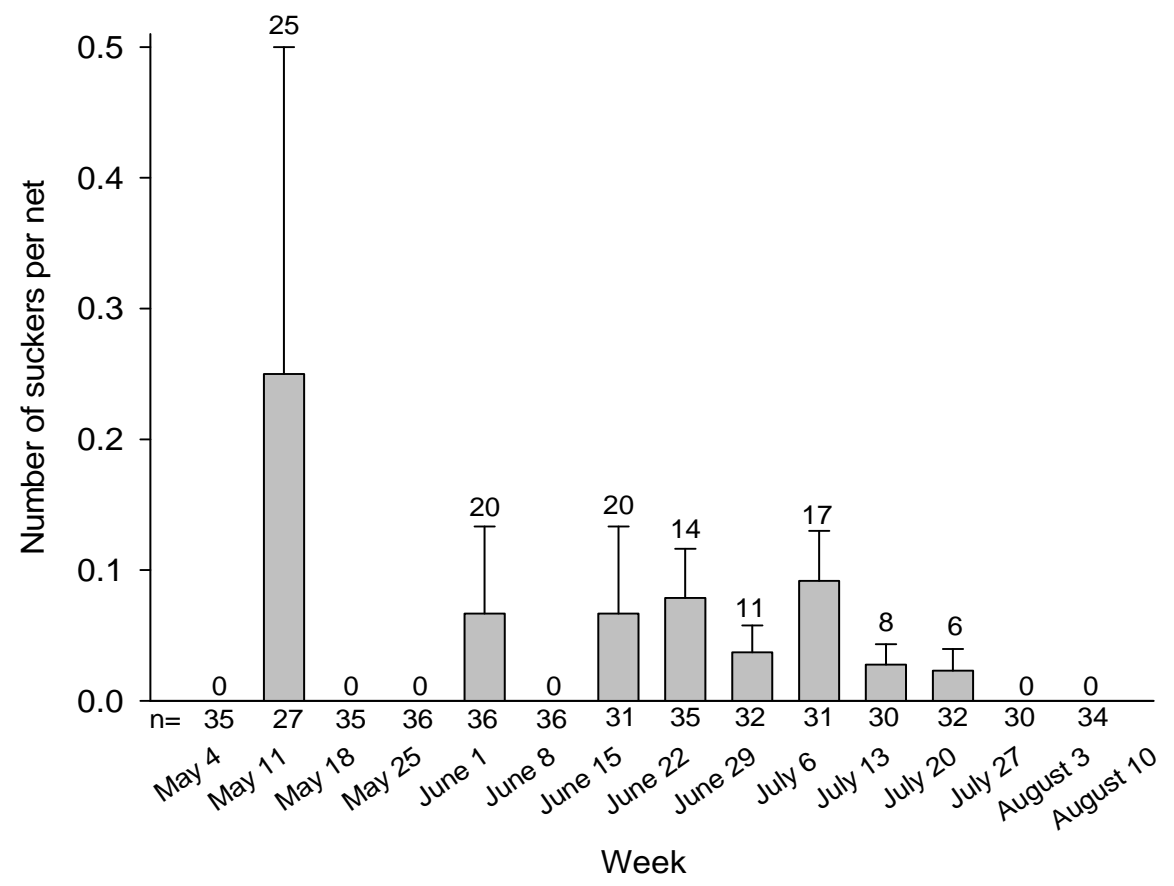

Figure 16. Mean ( \pm SE) weekly catch per unit effort (suckers per net) for age-1 suckers caught in trap nets set over night in the Tulana Unit of the Williamson River Delta and southern Agency Lake, Oregon, between May 5 and July 25, 2008. The percentage of sites at which at least one sucker was caught and the number of sites sampled each week are given above and below the $\mathrm{x}$-axis, respectively. 


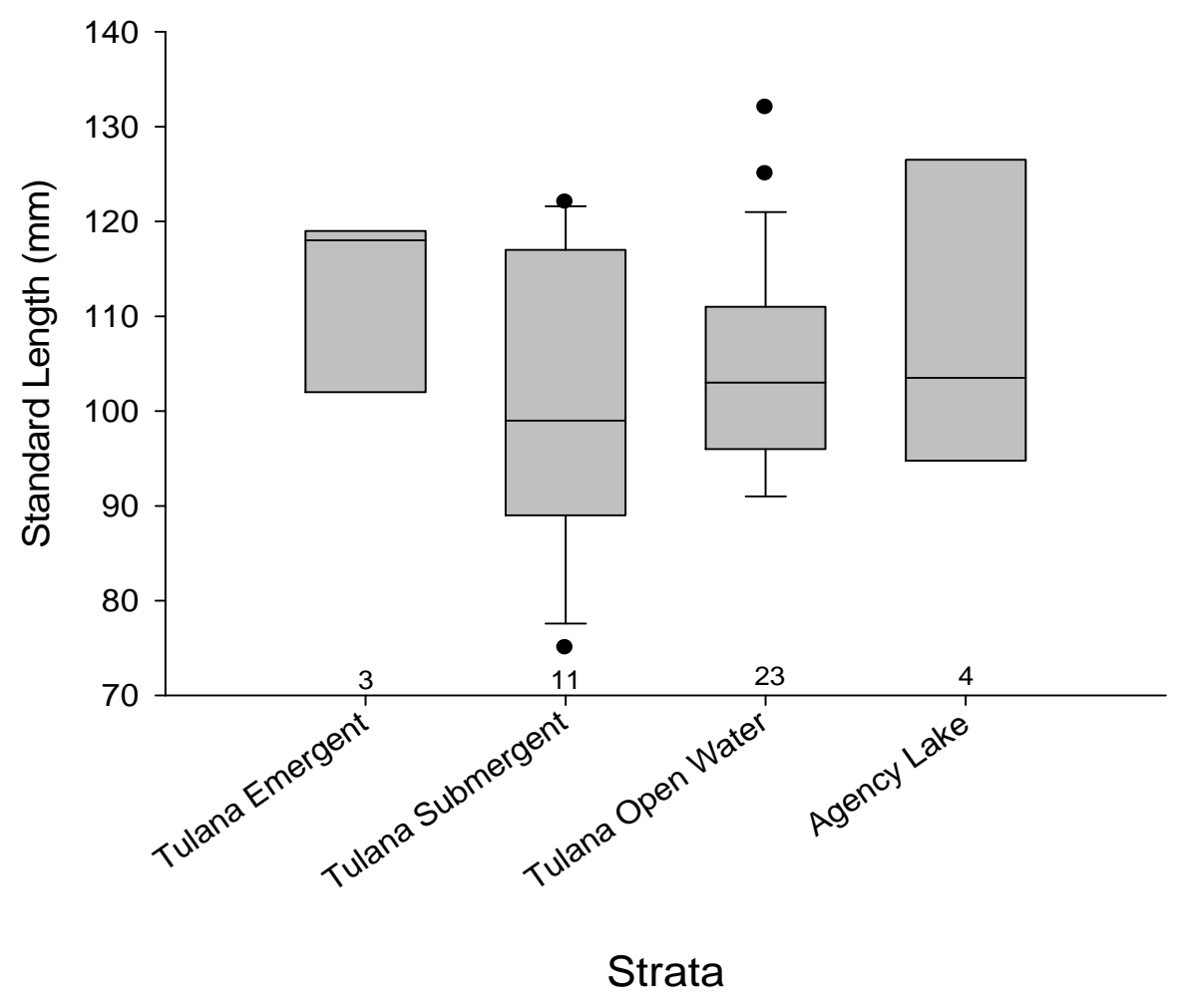

Figure 17. Standard length $(\mathrm{mm})$ of age-1 suckers caught in trap net sampling in three strata in the Tulana Unit of the Williamson River Delta and one stratum located in southern Agency Lake, Oregon, between May 5 and July 25,2008 . Boxplots indicate the $25^{\text {th }}, 50^{\text {th }}$, and $75^{\text {th }}$ percentiles, the whiskers indicate $5^{\text {th }}$ and $95^{\text {th }}$ percentiles and circles indicate outliers. 

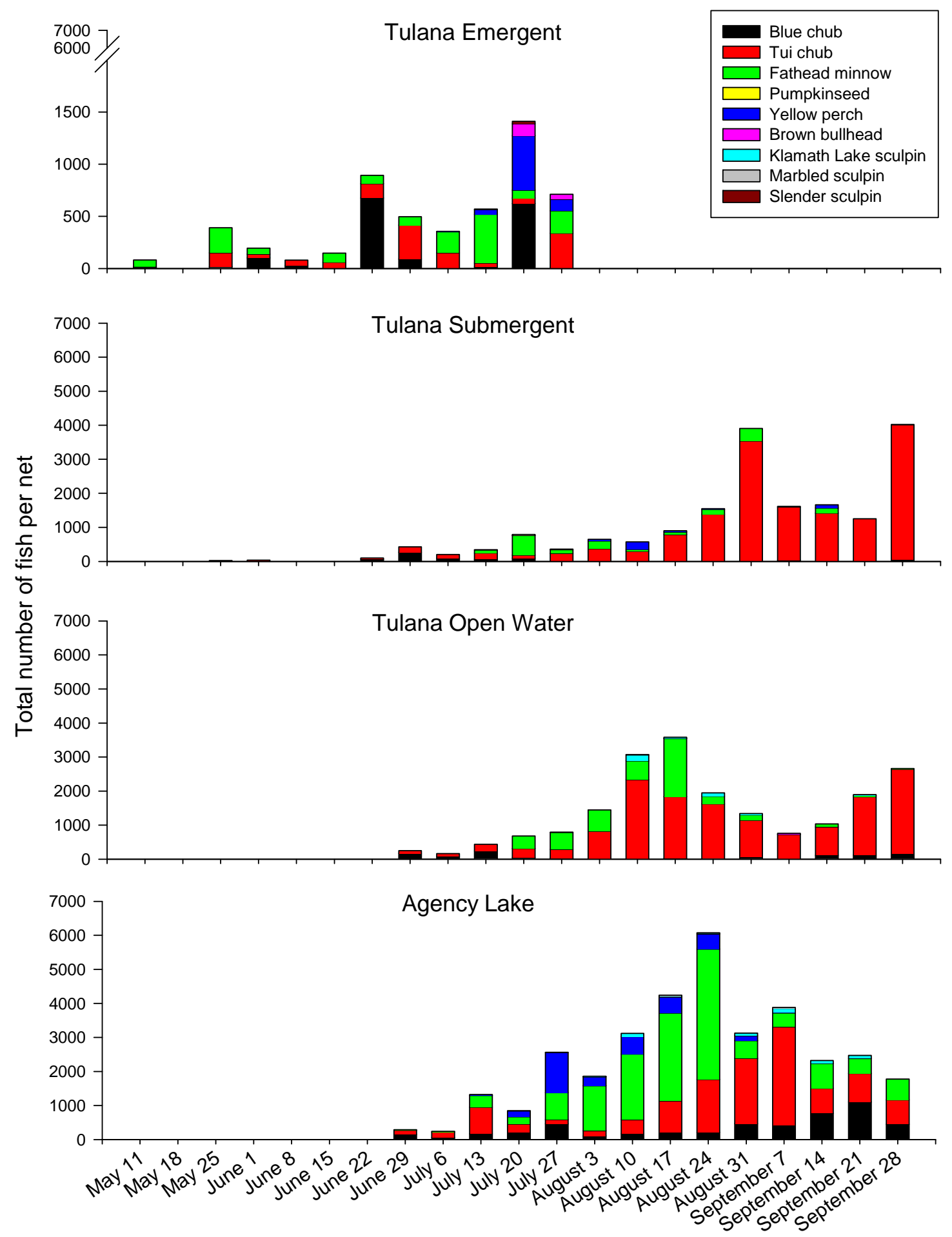

Figure 18. Number of juvenile or small adult fish caught per overnight trap net sample, by week and species. Nets were set in three strata (fig. 1) in the Tulana Unit of the Williamson River Delta and one strata in southern Agency Lake, Oregon, between May 5 and September 25, 2008. Notice the difference in the $y$-axis scale for the Tulana Emergent stratum (top), compared to the other three strata. 


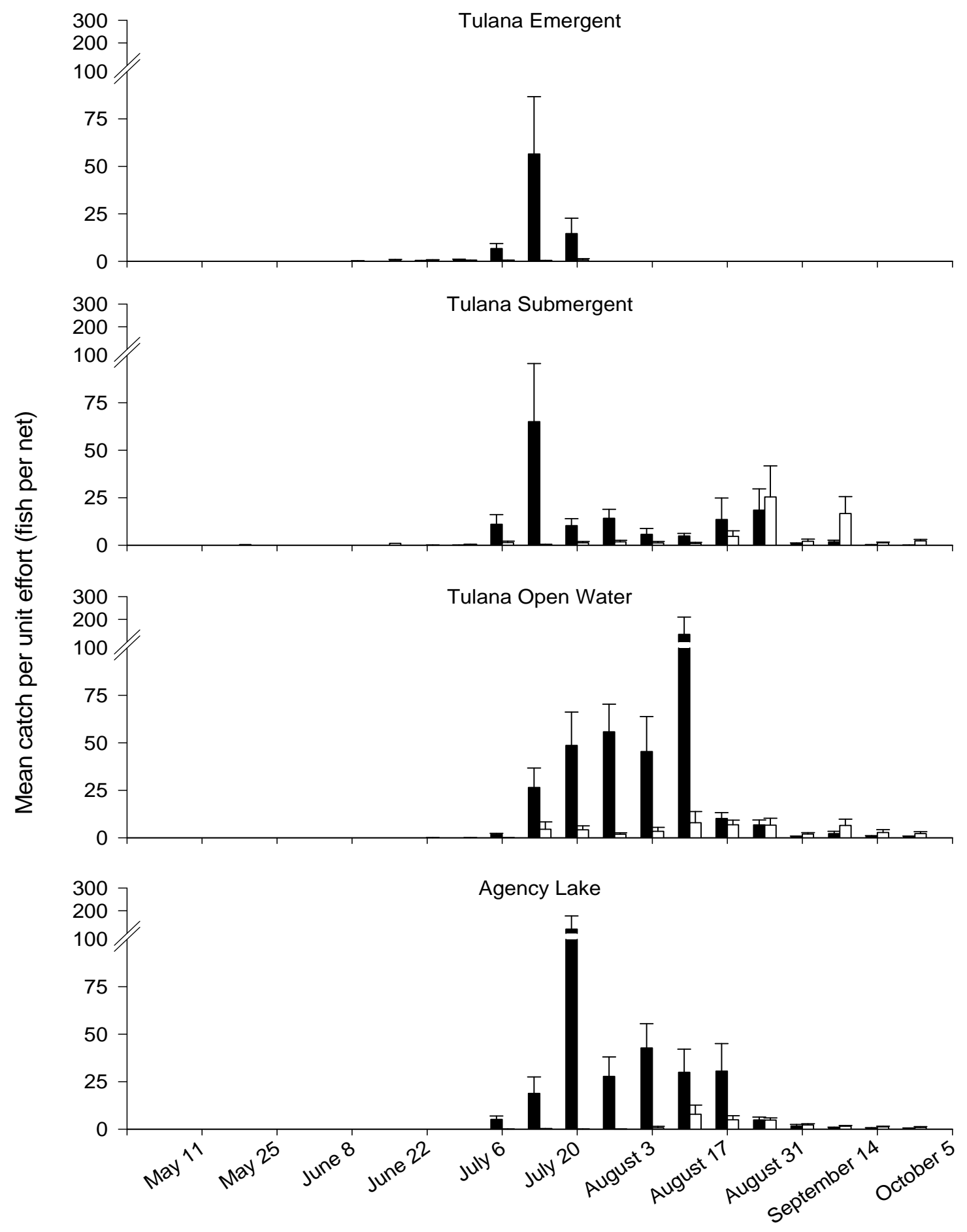

Figure 19. Weekly mean ( \pm SE) catch per unit effort (fish per net) for two cohorts of yellow perch caught in trap nets set over night in the Tulana Unit of the Williamson River Delta and one strata in southern Agency Lake, Oregon, between May 5 and September 25, 2008. The smaller (26 to 69 $\mathrm{mm} \mathrm{SL}$ ) cohort is shown in black and the larger cohort (70 to $209 \mathrm{~mm} \mathrm{SL}$ ) is shown in white. 


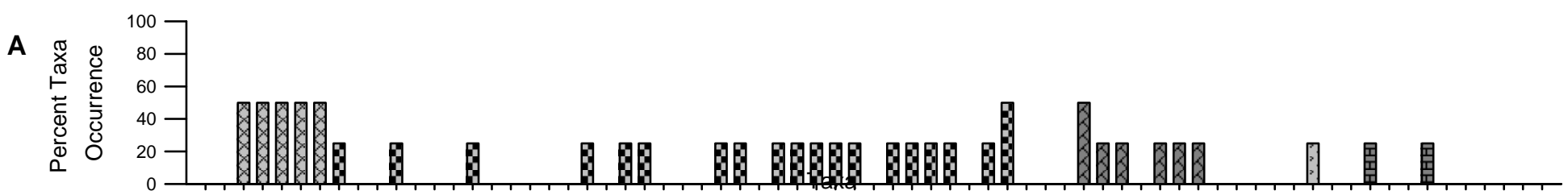

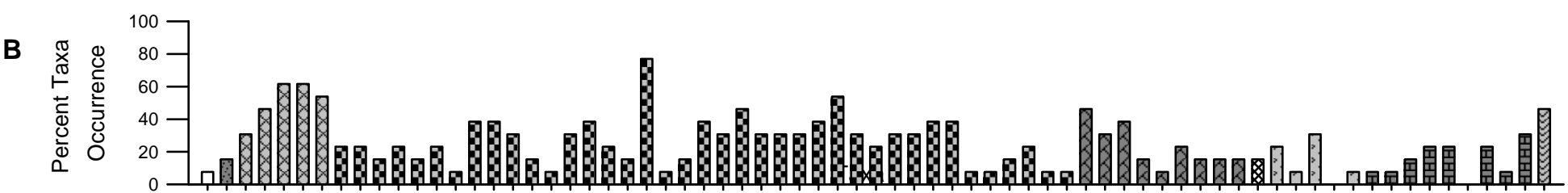

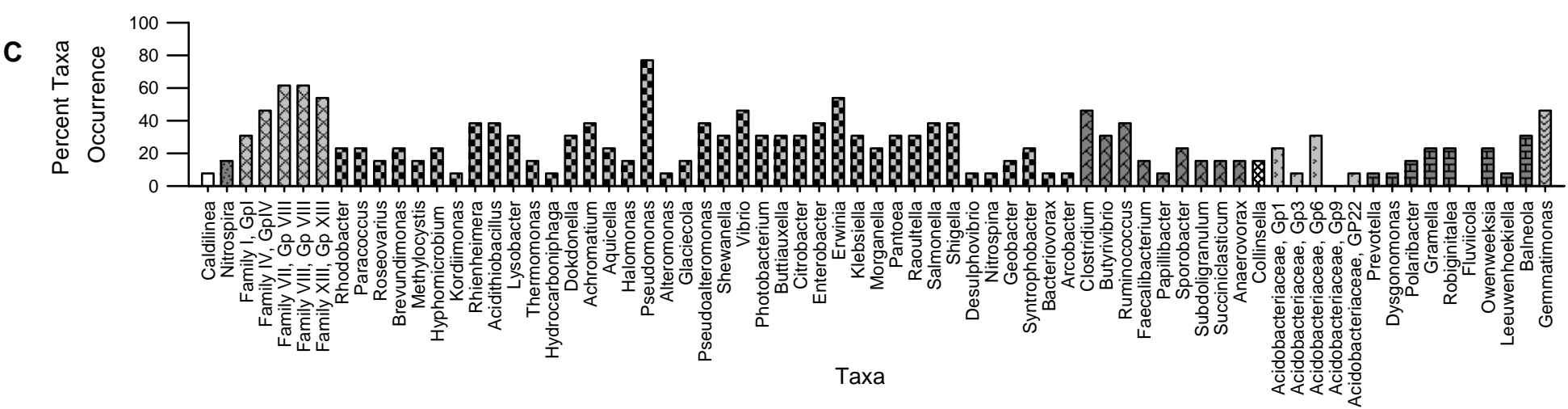

Figure 20. Percent occurrence of bacterial genera from the skin mucous of individual age-0 juvenile suckers collected from Agency Lake (A, $n=4)$, Tulana Submerged Vegetation (B, $n=14)$, or Tulana Open Water $(C, n=38)$ adjacent to Upper Klamath Lake, Oregon, July 29-September 17, 2008. Bars coded by phyla: Chlorflexi - white bar, no fill; Nitrospira - dark gray, dotted; Cyanobacteria - light gray, large crosshatch; Proteobacteria - light gray, checkered; Firmicutes - dark gray, diagonal brick; Actinobacteria - white bar, small crosshatch; Acidobacteria - light gray, arrows; Bacteroidetes - dark gray, horizontal brick; Gemmatimonadetes - light gray, waves. Full taxonomic descriptions of the genera are provided in table 13. 
A

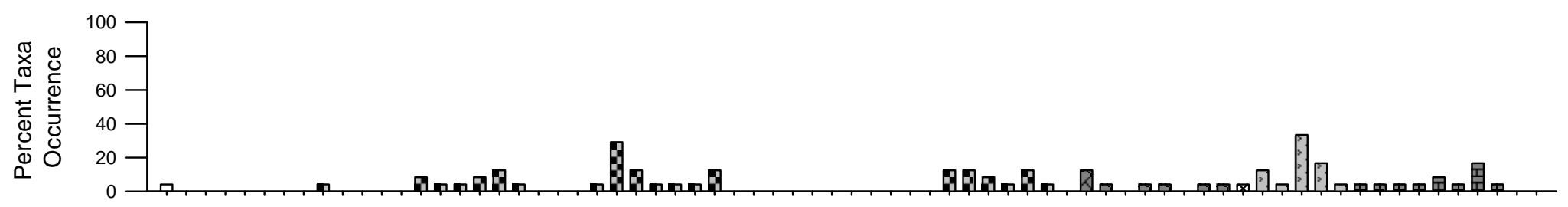

B

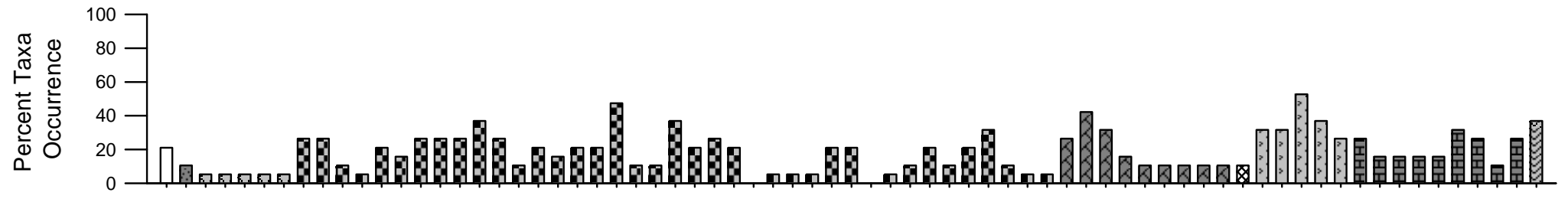

C

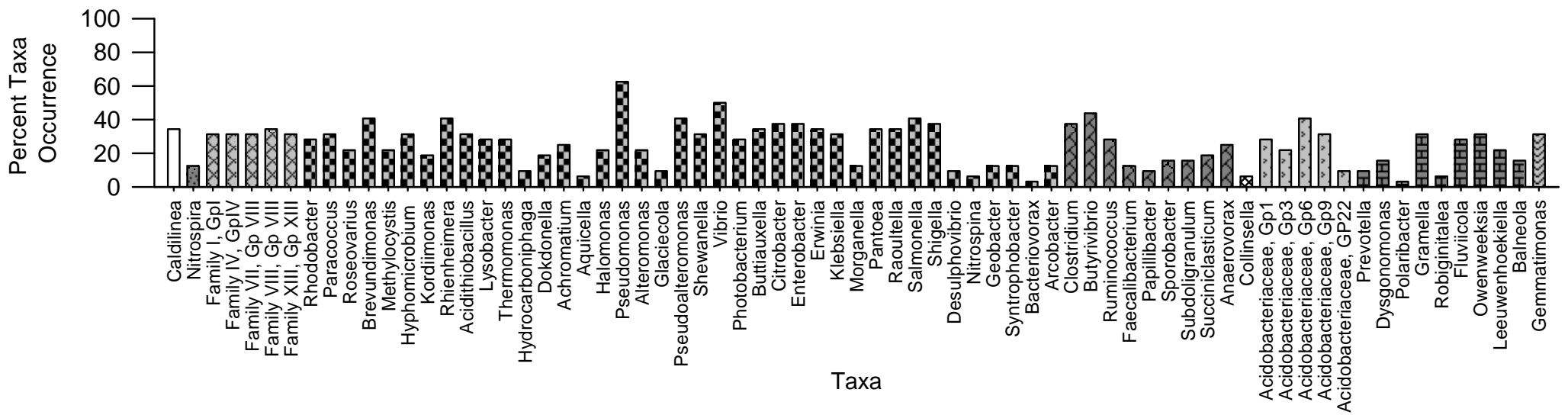

Figure 21 Percent occurrence of bacterial genera from the skin mucous of individual age-0 juvenile suckers collected from near-shore areas in the southern ( $A, n=24)$, central $(B, n=19)$, or northern $(C, n=33)$ regions of Upper Klamath Lake, Oregon, July 31-August 28,2008 . Bars coded by phyla: Chlorflexi - white bar, no fill; Nitrospira - dark gray, dotted; Cyanobacteria - light gray, large crosshatch; Proteobacteria - light gray, checkered; Firmicutes - dark gray, diagonal brick; Actinobacteria - white bar, small crosshatch; Acidobacteria - light gray, arrows; Bacteroidetes dark gray, horizontal brick; Gemmatimonadetes - light gray, waves. Full taxonomic descriptions of the genera are provided in table 13. 
A

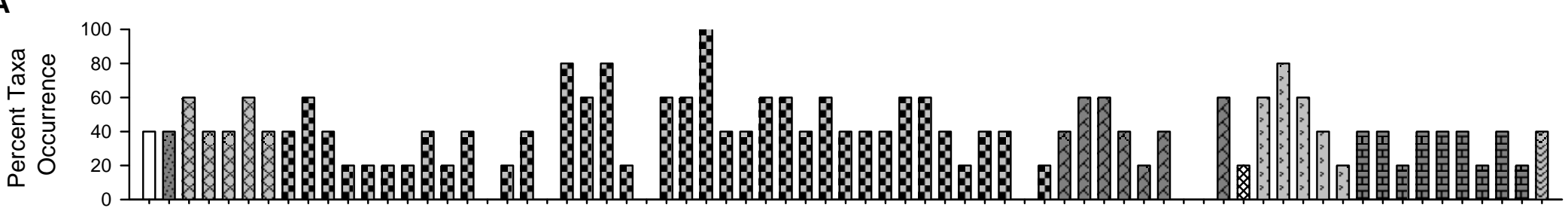

B

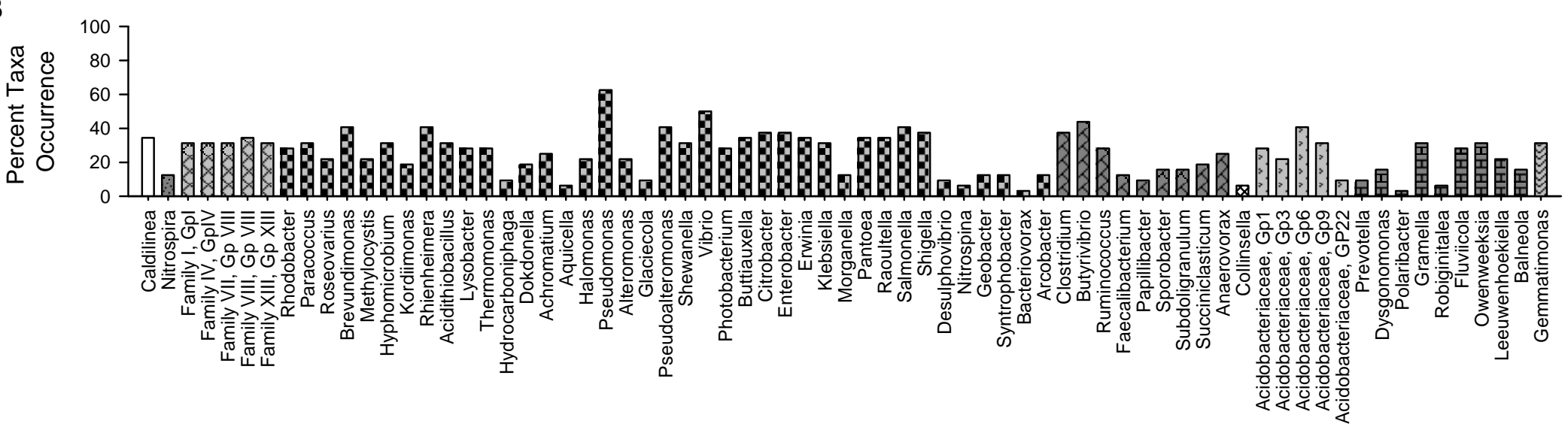

Taxa

Figure 22. Percent occurrence of bacterial genera from the skin mucous of individual age-0 juvenile suckers collected from off-shore $(A, n=5)$ or near-shore $(B, n=33)$ areas, within the northern region of Upper Klamath Lake, Oregon, July 28-August 28, 2008. Bars coded by phyla: Chlorflexi white bar, no fill; Nitrospira - dark gray, dotted; Cyanobacteria - light gray, large crosshatch; Proteobacteria - light gray, checkered; Firmicutes dark gray, diagonal brick; Actinobacteria - white bar, small crosshatch; Acidobacteria - light gray, arrows; Bacteroidetes - dark gray, horizontal brick; Gemmatimonadetes - light gray, waves. Full taxonomic descriptions of the genera are provided in table 13. 
A

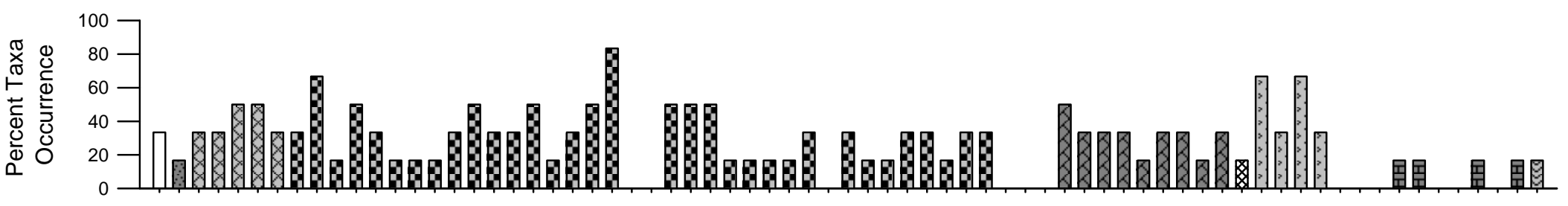

B

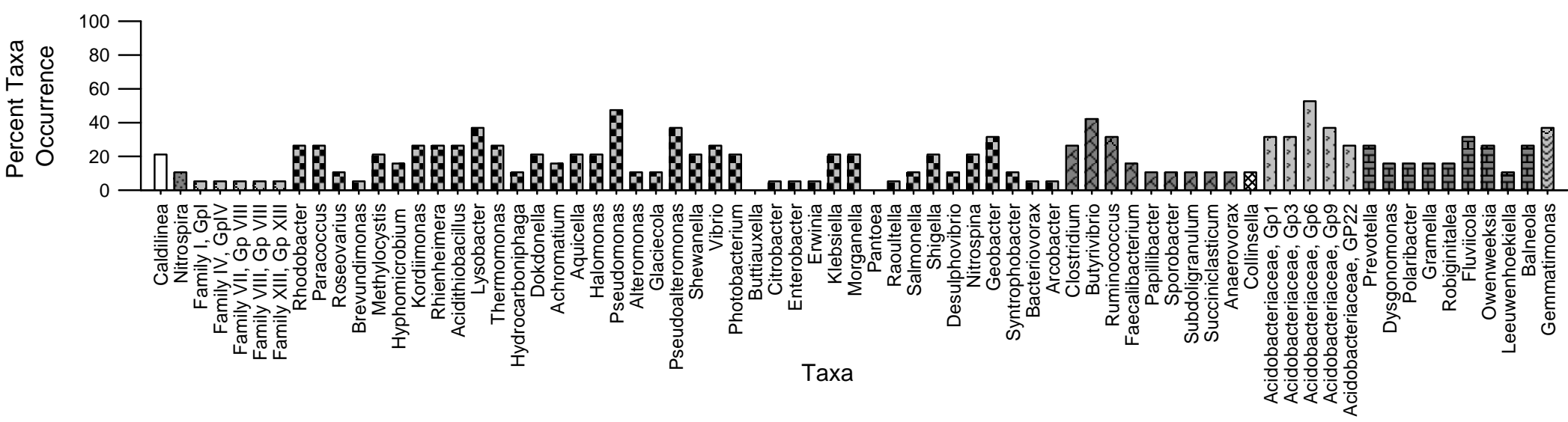

Figure 23. Percent occurrence of bacterial genera from the skin mucous of individual age-0 juvenile suckers collected from off-shore (A, $n=6)$ or near-shore areas $(B, n=19)$, within the central region of Upper Klamath Lake, Oregon, July 29_August 26, 2008. Bars coded by phyla: Chlorflexi white bar, no fill; Nitrospira - dark gray, dotted; Cyanobacteria - light gray, large crosshatch; Proteobacteria - light gray, checkered; Firmicutes dark gray, diagonal brick; Actinobacteria - white bar, small crosshatch; Acidobacteria - light gray, arrows; Bacteroidetes - dark gray, horizontal brick; Gemmatimonadetes - light gray, waves. Full taxonomic descriptions of the genera are provided in table 13. 
A

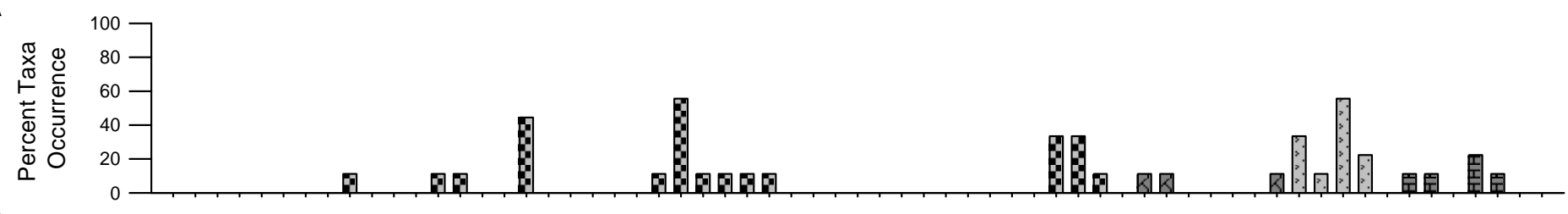

B

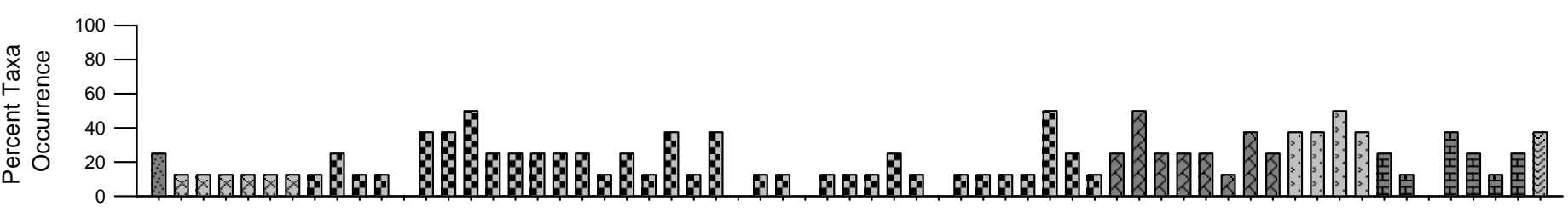

C

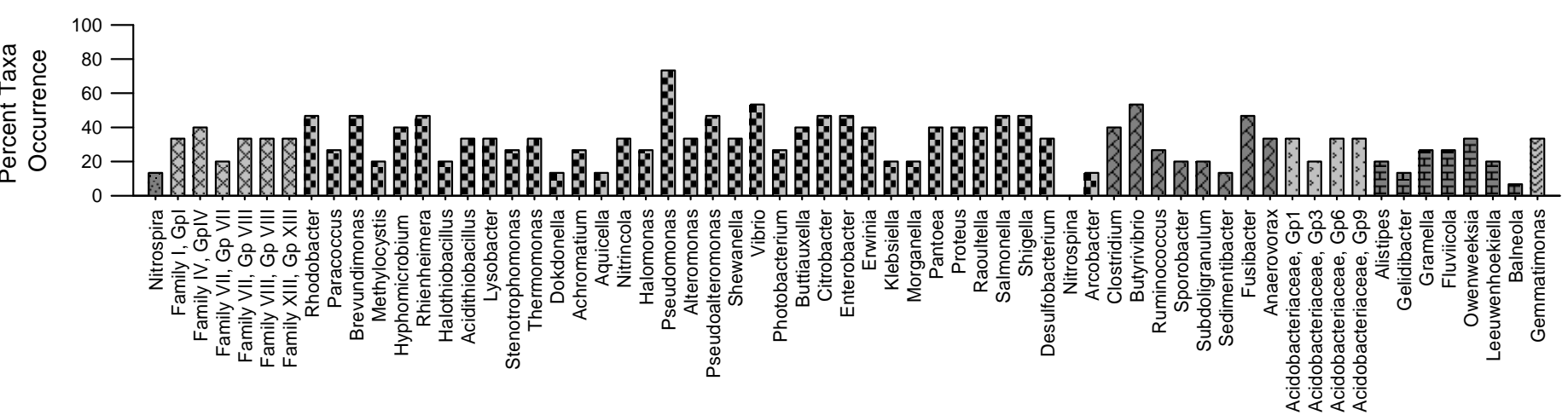

Taxa

Figure 24. Percent occurrence of bacterial genera from the skin mucous of individual age- 0 juvenile shortnose suckers collected from near-shore areas in the southern $(A, n=9)$, central $(B, n=8)$, or northern $(C, n=15)$ regions of Upper Klamath Lake, Oregon, July 31-August 28, 2008. Bars coded by phyla: Nitrospira - dark gray, dotted; Cyanobacteria - light gray, large crosshatch; Proteobacteria - light gray, checkered; Firmicutes dark gray, diagonal brick; Actinobacteria - white bar, small crosshatch; Acidobacteria - light gray, arrows; Bacteroidetes - dark gray, horizontal brick; Gemmatimonadetes - light gray, waves. Full taxonomic descriptions of the genera are provided in table 13. Dataset excludes fish from which no bacteria were detected. 
A
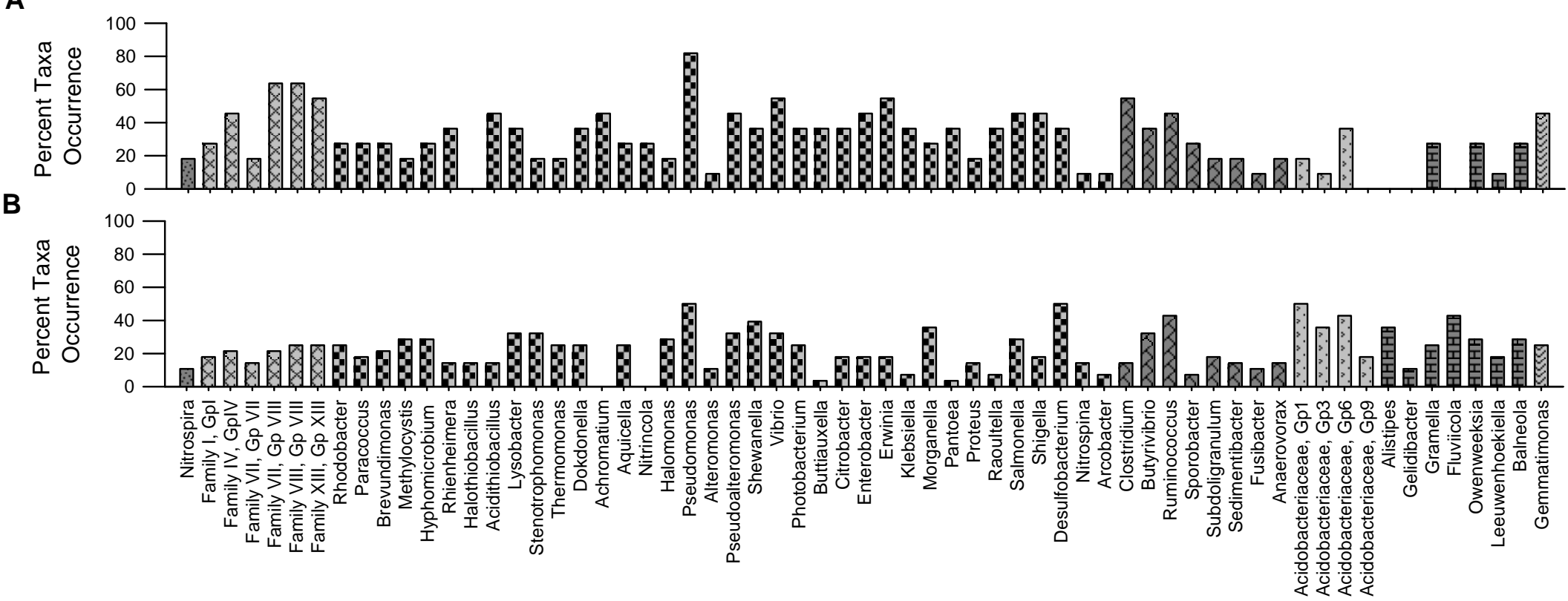

Taxa

Figure 25. Percent occurrence of bacterial genera from the skin mucous of individual age-0 juvenile shortnose suckers collected from Tulana Submerged Vegetation ( $\mathrm{A}, \mathrm{n}=11$ ), or Tulana Open Water $(\mathrm{B}, \mathrm{n}=\mathbf{2 8}$ ) adjacent to Upper Klamath Lake, Oregon, July 29-September 17, 2008. Bars coded by phyla: Nitrospira - dark gray, dotted; Cyanobacteria - light gray, large crosshatch; Proteobacteria - light gray, checkered; Firmicutes dark gray, diagonal brick; Actinobacteria - white bar, small crosshatch; Acidobacteria - light gray, arrows; Bacteroidetes - dark gray, horizontal brick; Gemmatimonadetes - light gray, waves. Full taxonomic descriptions of the genera are provided in table 13. Dataset excludes fish from which no bacteria were detected. 


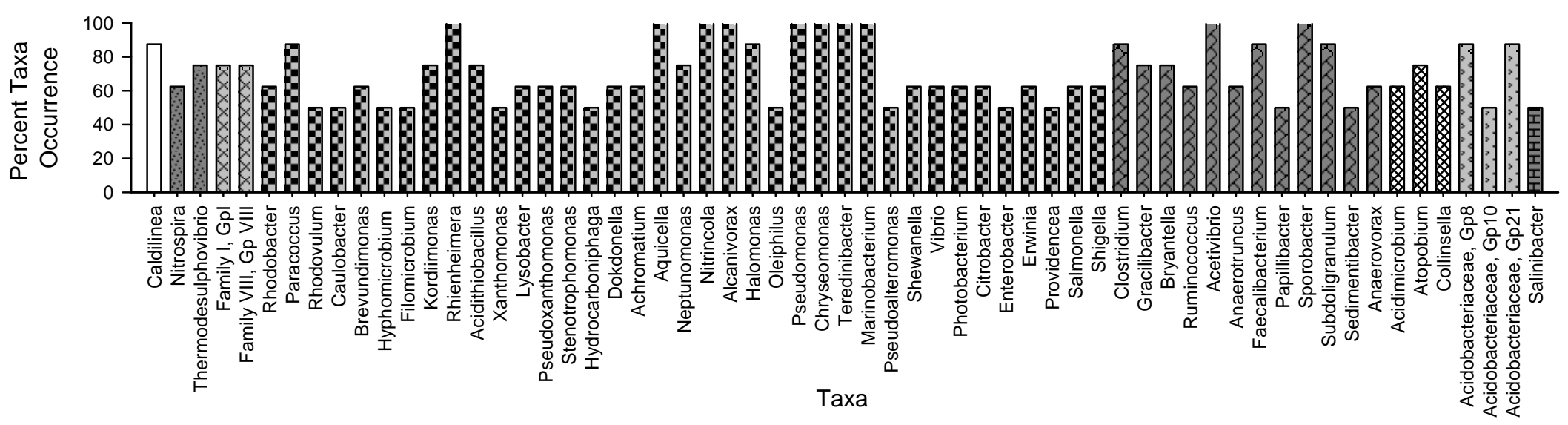

Figure 26. Percent occurrence of bacterial genera from the skin mucous of individual age-0 juvenile suckers collected from Clear Lake Reservoir, Modoc County, California $(n=8)$,September 16-18, 2008. Bars coded by phyla: Chlorflexi - white bar, no fill; Nitrospira - dark gray, dotted; Cyanobacteria - light gray, large crosshatch; Proteobacteria - light gray, checkered; Frmicutes - dark gray, diagonal brick; Actinobacteria - white bar, small crosshatch; Acidobacteria - light gray, arrows; Bacteroidetes - dark gray, horizontal brick; Gemmatimonadetes - light gray, waves. Full taxonomic descriptions of the genera are provided in table 13. Note: Only those genera that occurred in 50 percent or more of the individual fish samples are included. Data are indicative of taxa presence only. 


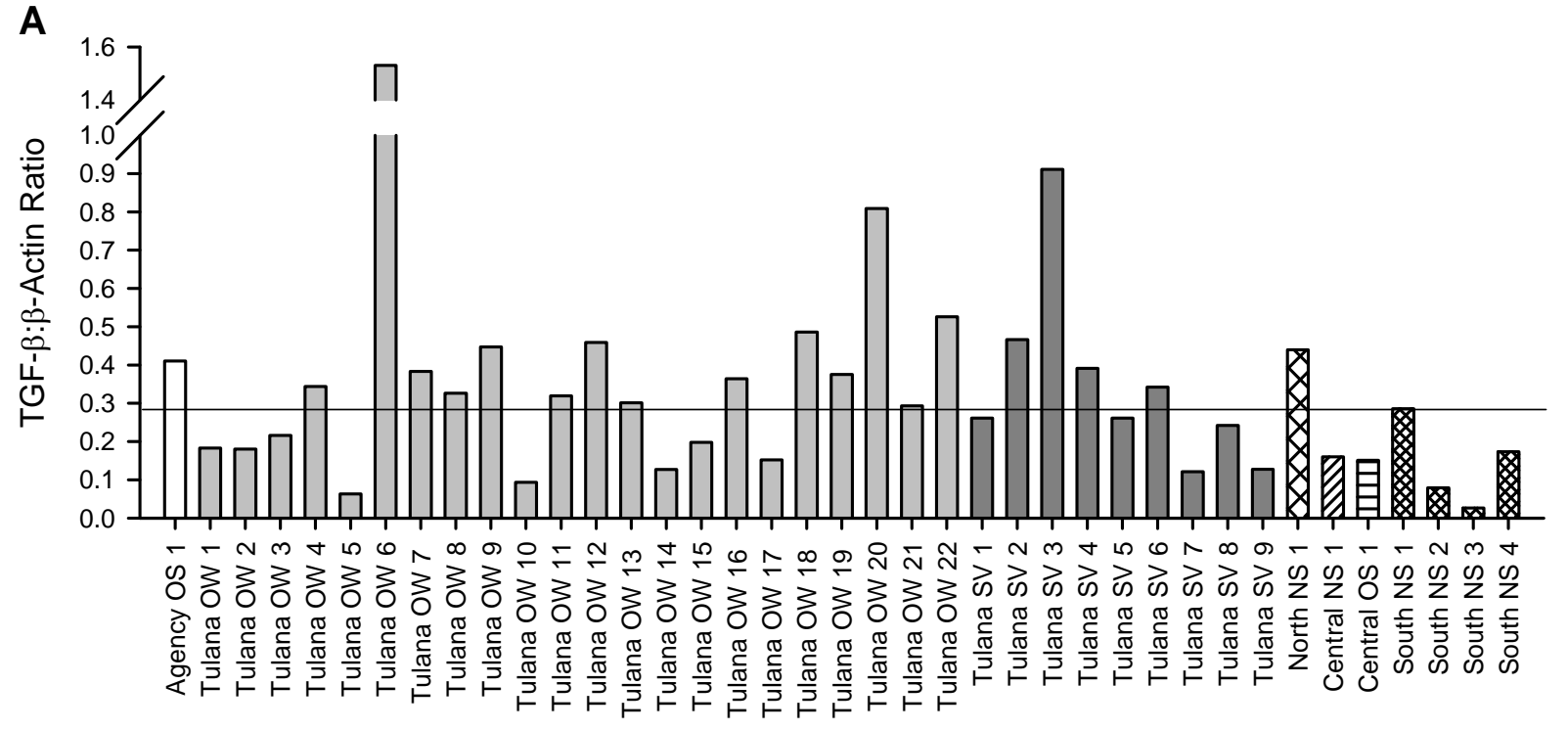

Young-of-Year Shortnose Suckers by Region

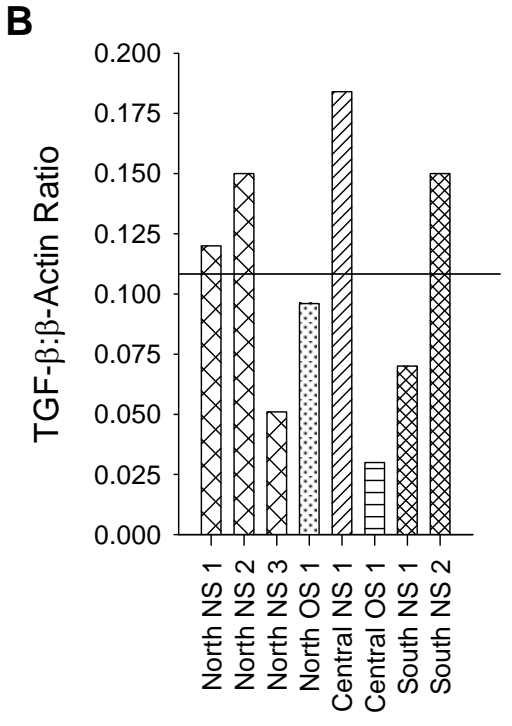

Young-of-Year Lost River Suckers by Region

Figure 27. Transforming Growth Factor $-B(T G F-B) m R N A$ expression in putative spleen tissue from age- 0 juvenile shortnose (A) and Lost River (B) suckers collected in or near Upper Klamath Lake (UKL), Oregon, July 28-September 18, 2008. Bars coded as follows: Agency Lake off shore (Agency OS) - white bar, no fill; Tulana Open Water (Tulana OW) - light gray bar, no fill; Tulana submerged vegetation (Tulana SV) - dark gray bar, no fill; UKL northern region near shore (North NS) - white bar, coarse crosshatch; UKL northern region off shore (North OS) - white bar, dotted; UKL central region near shore (Central NS) - white bar, diagonal lines; UKL central region off shore (Central OS) - white bar, horizontal lines; UKL

southern region near shore (South NS) - white bar, small crosshatch. Solid lines across the plots are the median values for the species specific data. Note the differences in the TGF-ß:ß-Actin Ratio scales on the two plots. TGF-ß:ß-Actin Ratio are species specific, therefore the values should not be compared between shortnose and Lost River suckers. 
This page left intentionally blank 
Table 1. Number of visits and mean site depth at each fixed plankton sample location in and adjacent to the Williamson River Delta, Oregon.

[See figure 1 for location of sampling strata. Depths were measured during each weekly sampling occasion, which occurred between May 5 and July 18, 2008. The Tulana Emergent stratum was only sampled from May 27 to July 18, 2008. SE, standard error; ft, feet]

\begin{tabular}{lccc}
\hline \multicolumn{1}{c}{ Site } & $\begin{array}{c}\text { Number } \\
\text { of visits }\end{array}$ & $\begin{array}{c}\text { Mean } \\
\text { depth (ft) }\end{array}$ & \multicolumn{1}{|}{$\mathbf{\text { SE }}$} \\
\hline Tulana Emergent & 4 & 0.70 & 0.24 \\
Tulana Open Water & 10 & 3.08 & 0.11 \\
Williamson River Mouth & 14 & 4.66 & 0.14 \\
Breach 3 & 10 & 2.35 & 0.27 \\
Breach 4 & 16 & 1.61 & 0.08 \\
Breach 5 & 11 & 2.21 & 0.12 \\
Breach 6 & 13 & 1.95 & 0.09 \\
\hline
\end{tabular}

Table 2. Occurrence criteria applied to bacterial genera obtained in skin mucous samples from age-0 juvenile suckers collected in or near Upper Klamath Lake, Oregon, July 28-September 18, 2008.

[Criteria: Occurrence defined as the percentage of fish obtained in a given geographic area from which a given bacterial genus was obtained. Criteria were applied to data obtained from the following areas: Tulana Open Water; Tulana submerged vegetation; Northern Upper Klamath Lake near shore; Central Upper Klamath Lake near shore; Southern Upper Klamath Lake near shore. In order to be included in summary data, at least one of the five criteria had to be met]

\begin{tabular}{|l|l|}
\hline & \multicolumn{1}{|c|}{ Criteria } \\
\hline 1 & Genus detected in five geographic areas at any percent occurrence. \\
\hline 2 & Genus detected in four geographic areas at a percent occurrence of 10 percent or higher. \\
\hline 3 & Genus detected in three geographic areas at a percent occurrence of 20 percent or higher. \\
\hline 4 & Genus detected in two geographic areas at a percent occurrence of 30 percent or higher. \\
\hline 5 & Genus detected in one geographic area at a percent occurrence of 40 percent or higher. \\
\hline
\end{tabular}


Table 3. Mean sample density for Lost River and shortnose sucker larvae in random stratified plankton sampling conducted in four strata in and adjacent to the Williamson River Delta, Oregon.

[See figure 1 for location of sampling strata. With the exception of samples taken in the Tulana Emergent stratum, means were calculated for samples taken between May 20, when the first larval suckers were captured, and July 18 when we stopped sampling in all strata. In Tulana Emergent, sampling did not begin until May 27 and mean sample densities were calculated for all samples; SE, standard error]

\begin{tabular}{lccccc}
\hline & & \multicolumn{4}{c}{ Sample density } \\
\cline { 3 - 6 } \multicolumn{1}{c}{ Strata } & $\begin{array}{c}\text { Number of } \\
\text { Samples }\end{array}$ & \multicolumn{2}{c}{$\begin{array}{c}\text { Lost River } \\
\text { Shortnose or Klamath } \\
\text { Largescale }\end{array}$} \\
\cline { 3 - 6 } & & Mean & $\mathbf{\pm S E}$ & Mean & $\mathbf{\pm S E}$ \\
\hline Agency Lake & 15 & 0.014 & 0.011 & 0.005 & 0.004 \\
Upper Klamath Lake & 23 & 0.113 & 0.061 & 0.021 & 0.009 \\
Tulana Open Water & 18 & 0.009 & 0.004 & 0.006 & 0.004 \\
Tulana Emergent & 8 & 0.181 & 0.099 & 0.048 & 0.019 \\
\hline
\end{tabular}

Table 4. Percentage of larval Lost River suckers caught in plankton nets during random stratified sampling, with $0,25,50,75$, or 100 percent of their guts full of food in four sampling strata in and adjacent to the Williamson River Delta, Oregon.

\begin{tabular}{|c|c|c|c|c|c|}
\hline \multirow[b]{2}{*}{ Strata } & \multicolumn{5}{|c|}{ Percent gut fullness } \\
\hline & 0 & 25 & 50 & 75 & 100 \\
\hline Agency Off Shore & 33 & 0 & 33 & 33 & 0 \\
\hline Upper Klamath Lake & 16 & 45 & 18 & 16 & 5 \\
\hline Tulana Open Water & 0 & 17 & 33 & 17 & 33 \\
\hline Tulana Emergent & 0 & 17 & 13 & 52 & 17 \\
\hline Grand Total & 12 & 36 & 19 & 24 & 9 \\
\hline
\end{tabular}

Table 5. Percentage of larvae identified as either Klamath largescale or shortnose suckers caught in plankton nets during random stratified sampling, with $0,25,50,75$, or 100 percent of their guts full of food from four sampling strata in and adjacent to the Williamson River Delta, Oregon.

[See figure 1 for location of sampling strata]

\begin{tabular}{|c|c|c|c|c|c|}
\hline \multirow[b]{2}{*}{ Strata } & \multicolumn{5}{|c|}{ Percent gut fullness } \\
\hline & 0 & 25 & 50 & 75 & 100 \\
\hline Agency Off Shore & 0 & 0 & 50 & 0 & 50 \\
\hline Upper Klamath Lake & 0 & 31 & 15 & 8 & 46 \\
\hline Tulana Open Water & 0 & 67 & 0 & 33 & 0 \\
\hline Tulana Emergent & 0 & 17 & 33 & 33 & 17 \\
\hline Grand Total & 0 & 29 & 21 & 17 & 33 \\
\hline
\end{tabular}


Table 6. Mean notochord length for larval Lost River suckers and larvae identified as either shortnose or Klamath largescale suckers, collected at each of seven fixed sampling sites in and adjacent to the Williamson River Delta, Oregon.

[See figure 1 for location of sampling strata. Each site was sampled weekly between May 5 and July 18, 2008. The numbers of larvae measured (n) throughout the sampling season are given for each site. A total of five larval Lost River suckers collected at the Williamson River mouth were not measured because a portion of their body was missing. SE, standard error; mm, millimeter]

\begin{tabular}{|c|c|c|c|c|}
\hline \multirow[b]{2}{*}{ Strata } & \multicolumn{2}{|c|}{ Lost River sucker } & \multicolumn{2}{|c|}{$\begin{array}{c}\text { Shortnose/Klamath } \\
\text { largescale sucker }\end{array}$} \\
\hline & $\mathbf{n}$ & $\begin{array}{c}\text { mean }( \pm S E) \\
(\mathrm{mm})\end{array}$ & $\mathbf{n}$ & $\begin{array}{c}\text { mean (SE) } \\
(\mathrm{mm})\end{array}$ \\
\hline Tulana Emergent & 16 & $12.5 \pm 0.1$ & 65 & $13.1 \pm 0.2$ \\
\hline Tulana Open Water & 2 & $12 \pm 0$ & 2 & $15.3 \pm 0.8$ \\
\hline Williamson River Mouth & 399 & $12.0 \pm 0.04$ & 15 & $12.1 \pm 0.2$ \\
\hline Breach 3 & 7 & $12.9 \pm 0.2$ & 0 & \\
\hline Breach 4 & 0 & & 0 & \\
\hline Breach 5 & 0 & & 1 & $9 \pm 0$ \\
\hline Breach 6 & 3 & $10.8 \pm 0.9$ & 0 & \\
\hline
\end{tabular}

Table 7. Number of repeat visits at sites sampled for juvenile fish in and adjacent to the Williamson River Delta, Oregon, between May 5 and September 25, 2008.

\begin{tabular}{cc}
\hline Repeat visits & Sites \\
\hline 1 & 109 \\
2 & 14 \\
3 & 35 \\
4 & 51 \\
5 & 9 \\
\hline Total sites & 218 \\
\hline
\end{tabular}


Table 8. Number of sites successfully sampled for juvenile fish in three strata in the Tulana Unit of the Williamson River Delta and one stratum in southern Agency Lake, Oregon, 2008.

[See figure 1 for location of sampling strata. The number of sites at which one, two, or three nets was set in each season is given. The seasons are defined as spring (May 5 to June 19), mid-summer (June 23 to July 31), and late summer (August 4 to September 25). Four nets set at two sites in the Tulana Emergent stratum during the mid-summer time period failed to effectively sample fish and were removed from the dataset]

\begin{tabular}{|c|c|c|c|c|c|}
\hline \multirow{7}{*}{$\begin{array}{l}\text { 을 } \\
\text { ஸे }\end{array}$} & \multicolumn{5}{|c|}{ Number of nets } \\
\hline & Strata & 1 & 2 & 3 & Subtota \\
\hline & Agency Off Shore & 7 & 0 & 0 & 7 \\
\hline & Tulana Emergent & 7 & 0 & 5 & 12 \\
\hline & Tulana Open Water & 7 & 0 & 0 & 7 \\
\hline & Tulana Submergent & 0 & 0 & 6 & 6 \\
\hline & Subtotal & 21 & 0 & 11 & 32 \\
\hline \multirow{7}{*}{ 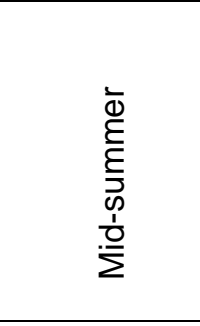 } & \multicolumn{5}{|c|}{ Number of Nets } \\
\hline & Strata & 1 & 2 & 3 & Subtota \\
\hline & Agency Off Shore & 0 & 0 & 58 & 58 \\
\hline & Tulana Emergent & 0 & 1 & 33 & 34 \\
\hline & Tulana Open Water & 0 & 0 & 57 & 57 \\
\hline & Tulana Submergent & 0 & 0 & 56 & 56 \\
\hline & Subtotal & 0 & 1 & 204 & 205 \\
\hline \multirow{7}{*}{ 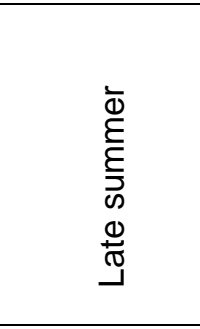 } & \multicolumn{5}{|c|}{ Number of Nets } \\
\hline & Strata & 1 & 2 & 3 & Subtota \\
\hline & Agency Off Shore & 92 & 0 & 3 & 95 \\
\hline & Tulana Emergent & 0 & 0 & 0 & 0 \\
\hline & Tulana Open Water & 88 & 0 & 4 & 92 \\
\hline & Tulana Submergent & 66 & 1 & 1 & 68 \\
\hline & Subtotal & 246 & 1 & 8 & 255 \\
\hline Grand Total & & & & & 492 \\
\hline
\end{tabular}


Table 9. Numbers of sites at which three successful trap net samples were taken each week in three strata within the Williamson River Delta and one stratum in southern Agency Lake, Oregon.

[See figure 1 for location of sampling strata. The Tulana Emergent stratum was to shallow to navigate by boat or sample after the week of July 20]

\begin{tabular}{|c|c|c|c|c|c|}
\hline \multirow[b]{2}{*}{ Week } & \multicolumn{4}{|c|}{ Strata } & \multirow[b]{2}{*}{ Total } \\
\hline & $\begin{array}{c}\text { Tulana } \\
\text { Emergent }\end{array}$ & $\begin{array}{c}\text { Tulana } \\
\text { Submergent }\end{array}$ & $\begin{array}{c}\text { Tulana Open } \\
\text { Water }\end{array}$ & Agency Lake & \\
\hline May 3 & & & & & \\
\hline May 11 & & 1 & & & 1 \\
\hline May 18 & 1 & 1 & & & 2 \\
\hline May 25 & 1 & 1 & & & 2 \\
\hline June 1 & 1 & 1 & & & 2 \\
\hline June 8 & 1 & 1 & & & 2 \\
\hline June 15 & 1 & 1 & & & 2 \\
\hline June 22 & 8 & 7 & 10 & 10 & 35 \\
\hline June 29 & 6 & 6 & 7 & 8 & 27 \\
\hline July 6 & 7 & 8 & 10 & 10 & 36 \\
\hline July 13 & 7 & 9 & 10 & 10 & 36 \\
\hline July 20 & 5 & 10 & 10 & 10 & 36 \\
\hline July 27 & & 16 & 10 & 10 & 36 \\
\hline August 3 & & 1 & 3 & 3 & 7 \\
\hline August 10 & & & 1 & & 1 \\
\hline Total & 40 & 63 & 60 & 61 & 225 \\
\hline
\end{tabular}


Table 10. Taxa of invertebrates identified in benthic grab samples collected in five strata in and adjacent to the Williamson River Delta, Oregon.

[See figure 1 for location of sampling strata. The percentages of samples in which each taxa was detected are given for each stratum. Taxa known to be prey of age-0 juvenile Lost River or shortnose suckers are denoted with a star $(*)]$

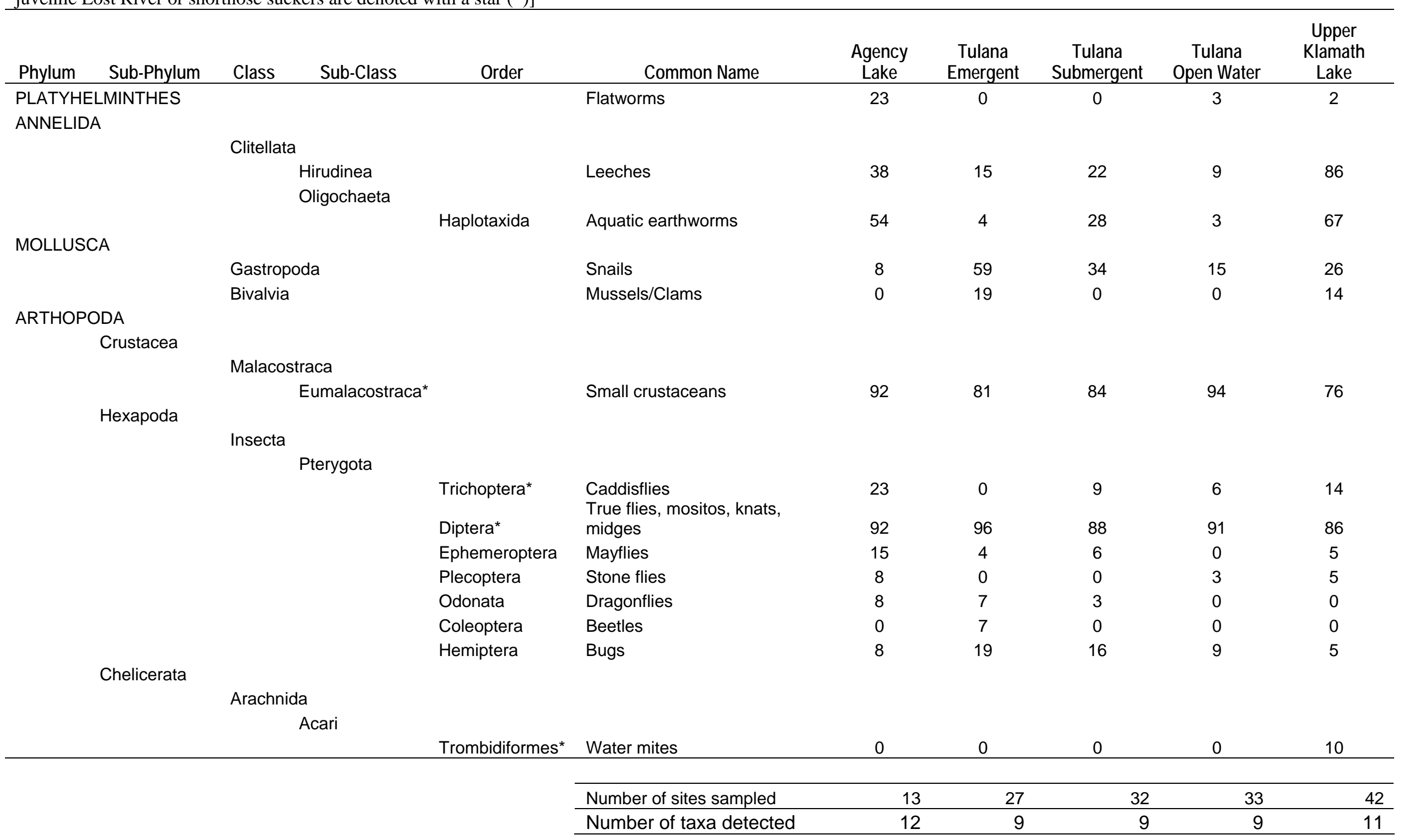


Table 11. Mean species richness and diversity of juvenile and small adult fish species captured in trap nets set in three strata in the Williamson River Delta and one stratum in southern Agency Lake, Oregon.

[See figure 1 for location of sampling strata. Richness was calculated as the number of species or taxa represented in a given sample. Diversity was calculated using the Shannon-Wiener index of diversity, which describes how evenly species are represented within a sample (McCune and Grace, 2002). High values of diversity indicate more even representation by species in a sample or strata]

\begin{tabular}{lcc}
\hline \multicolumn{1}{c}{ Strata } & Richness & Diversity \\
\hline Tulana Emergent & $4.2 \pm 0.3$ & $0.82 \pm 0.05$ \\
Tulana Submergent & $4.8 \pm 0.1$ & $0.84 \pm 0.03$ \\
Tulana Open Water & $5.5 \pm 0.1$ & $0.91 \pm 0.03$ \\
Agency Lake & $6.2 \pm 0.1$ & $1.05 \pm 0.02$ \\
\hline
\end{tabular}


Table 12. Summary of age-0 juvenile suckers collected in or near Upper Klamath Lake, Oregon, or Clear Lake Reservoir, Modoc County, California, from July 28 to September 18, 2008, from which skin mucous samples were collected for bacterial analysis.

\begin{tabular}{|c|c|c|c|c|c|c|}
\hline \multirow[t]{2}{*}{ Sample area } & \multirow[t]{2}{*}{ Sample dates } & \multirow{2}{*}{$\begin{array}{c}\text { Total sucker } \\
\text { samples } \\
\text { analyzed }\end{array}$} & \multicolumn{4}{|c|}{ Identity of suckers } \\
\hline & & & $\begin{array}{l}\text { Lost River } \\
\text { sucker }\end{array}$ & $\begin{array}{c}\text { Shortnose } \\
\text { sucker }\end{array}$ & $\begin{array}{l}\text { Klamath } \\
\text { Largescale } \\
\text { sucker }\end{array}$ & $\begin{array}{c}\text { Unidentified } \\
\text { species }\end{array}$ \\
\hline Agency Lake & $\begin{array}{l}\text { July 28- } \\
\text { August 26, } \\
2008\end{array}$ & 4 & 2 & 1 & 0 & 1 \\
\hline $\begin{array}{l}\text { Tulana Open } \\
\text { Water }\end{array}$ & $\begin{array}{l}\text { July 29- } \\
\text { September } \\
16,2008\end{array}$ & 38 & 3 & 30 & 2 & 3 \\
\hline $\begin{array}{l}\text { Tulana } \\
\text { Submerged } \\
\text { Vegetation }\end{array}$ & $\begin{array}{l}\text { August 27- } \\
\text { September } \\
16,2008\end{array}$ & 14 & 0 & 11 & 2 & 1 \\
\hline $\begin{array}{l}\text { Northern } \\
\text { Region Near } \\
\text { Shore }\end{array}$ & $\begin{array}{l}\text { July 31- } \\
\text { August 28, } \\
2008\end{array}$ & 33 & 7 & 18 & 3 & 5 \\
\hline $\begin{array}{l}\text { Northern } \\
\text { Region Off } \\
\text { Shore }\end{array}$ & $\begin{array}{l}\text { July 28-30, } \\
2008\end{array}$ & 5 & 4 & 0 & 1 & 0 \\
\hline $\begin{array}{l}\text { Central } \\
\text { Region Near } \\
\text { Shore }\end{array}$ & $\begin{array}{l}\text { July 31- } \\
\text { August 26, } \\
2008\end{array}$ & 19 & 8 & 8 & 1 & 2 \\
\hline $\begin{array}{l}\text { Central } \\
\text { Region Off } \\
\text { Shore }\end{array}$ & $\begin{array}{l}\text { July 29-31, } \\
2008\end{array}$ & 6 & 4 & 2 & 0 & 0 \\
\hline $\begin{array}{l}\text { Southern } \\
\text { Region Near } \\
\text { Shore }\end{array}$ & $\begin{array}{l}\text { August 11- } \\
26,2008\end{array}$ & 24 & 5 & 12 & 1 & 6 \\
\hline $\begin{array}{l}\text { Southern } \\
\text { Region Off } \\
\text { Shore }\end{array}$ & July 30, 2008 & 1 & 0 & 0 & 0 & 1 \\
\hline $\begin{array}{l}\text { Clear Lake } \\
\text { Reservoir }\end{array}$ & $\begin{array}{l}\text { September } \\
16-18,2008\end{array}$ & 8 & 1 & 5 & 0 & 2 \\
\hline
\end{tabular}


Table 13. Complete taxonomic descriptions of bacterial genera obtained from the skin mucous of age-0 juvenile suckers collected in or near Upper Klamath Lake, Oregon, or Clear Lake Reservoir, Modoc County, California, July 28 to September 18, 2008.

\begin{tabular}{|c|c|c|c|c|c|c|}
\hline Phylum & Class & Subclass & Order & Suborder & Family & Genus \\
\hline Chlorflexi & Anaerolinae & Caldilineae & Caldilinales & & Caldilineacea & Caldilinea \\
\hline \multirow[t]{2}{*}{ Nitrospira } & Nitrospira & & Nitrospirales & & Nitrospiraceae & Nitrospira \\
\hline & & & & & & Thermodesulphovibrio \\
\hline \multirow[t]{6}{*}{ Cyanobacteria } & Cyanobacteria & & & & Family I & Gp I \\
\hline & & & & & Family IV & Gp IV \\
\hline & & & & & Family VII & Gp VII \\
\hline & & & & & & Gp VIII \\
\hline & & & & & Family VIII & Gp VIII \\
\hline & & & & & Family XIII & Gp XIII \\
\hline \multirow[t]{10}{*}{ Proteobacteria } & Alphaproteobacteria & & Rhodobacterales & & Rhodobacteraceae & Rhodobacter \\
\hline & & & & & & Paracoccus \\
\hline & & & & & & Rhodovulum \\
\hline & & & & & & Roseovarius \\
\hline & & & Caulobacterales & & Caulobacteraceae & Caulobacter \\
\hline & & & & & & Brevundimonas \\
\hline & & & Rhizobiales & & Methylocystaceae & Methylocystis \\
\hline & & & & & Hyphomicrobiaceae & Hyphomicrobium \\
\hline & & & & & & Filomicrobium \\
\hline & & & Kordiimonadales & & Kordiimonadaceae & Kordiimonas \\
\hline
\end{tabular}


Table 13. Complete taxonomic descriptions of bacterial genera obtained from the skin mucous of age-0 juvenile suckers collected in or near Upper Klamath Lake, Oregon, or Clear Lake Reservoir, Modoc County, California, July 28 to September 18, 2008._Continued

\begin{tabular}{|c|c|c|c|c|c|c|}
\hline $\begin{array}{l}\text { Phylum } \\
\text { Proteobacteria }\end{array}$ & $\begin{array}{c}\text { Class } \\
\text { Gammaproteobacteria }\end{array}$ & Subclass & $\begin{array}{l}\text { Order } \\
\text { Chromatiales }\end{array}$ & Suborder & $\begin{array}{r}\text { Family } \\
\text { Chromatiaceae }\end{array}$ & $\begin{array}{l}\text { Genus } \\
\text { Rhienheimera }\end{array}$ \\
\hline & & & & & Halothiobacillaceae & Halothiobacillus \\
\hline & & & Acidithiobacillales & & Acidithiobacillaceae & Acidithiobacillus \\
\hline & & & Xanthomonadales & & Xanthomonadaceae & Xanthomonas \\
\hline & & & & & & Lysobacter \\
\hline & & & & & & Pseudoxanthomonas \\
\hline & & & & & & Stenotrophomonas \\
\hline & & & Xanthomonadales & & Xanthomonadaceae & Thermomonas \\
\hline & & & & & & Hydrocarboniphaga \\
\hline & & & & & & Dokdonella \\
\hline & & & Thiotrichales & & Thiotrichaceae & Achromatium \\
\hline & & & Legionellales & & Coxiellaceae & Aquicella \\
\hline & & & Oceanospirialleles & & Oceanospirillaceae & Neptunomonas \\
\hline & & & & & & Nitrincola \\
\hline & & & & & Alcanivoraceae & Alcanivorax \\
\hline & & & & & Halomonodaceae & Halomonas \\
\hline & & & & & Oleiphilaceae & Oleiphilus \\
\hline & & & Pseudomonadales & & Pseudomonadaceae & Pseudomonas \\
\hline & & & & & & Chryseomonas \\
\hline & & & Alteromonadales & & Incertae sedis 7 & Teredinibacter \\
\hline
\end{tabular}


Table 13. Complete taxonomic descriptions of bacterial genera obtained from the skin mucous of age-0 juvenile suckers collected in or near Upper Klamath Lake, Oregon, or Clear Lake Reservoir, Modoc County, California, July 28 to September 18, 2008.-Continued

\begin{tabular}{|c|c|c|c|c|c|c|}
\hline Phylum & Class & Subclass & Order & Suborder & Family & Genus \\
\hline \multirow[t]{19}{*}{ Proteobacteria } & Gammaproteobacteria & & Alteromonadales & & Incertae sedis 7 & Marinobacterium \\
\hline & & & & & Alteromonadaceae & Alteromonas \\
\hline & & & & & & Glaciecola \\
\hline & & & & & Pseudoalteromonadaceae & Pseudoalteromonas \\
\hline & & & & & Shewanellaceae & Shewanella \\
\hline & & & Vibrionales & & Vibrionaceae & Vibrio \\
\hline & & & & & & Photobacterium \\
\hline & & & Enterobacteriales & & Enterobacteriaceae & Buttiauxella \\
\hline & & & & & & Citrobacter \\
\hline & & & & & & Enterobacter \\
\hline & & & & & & Erwinia \\
\hline & & & & & & Klebsiella \\
\hline & & & & & & Morganella \\
\hline & & & Enterobacteriales & & Enterobacteriaceae & Pantoea \\
\hline & & & & & & Proteus \\
\hline & & & & & & Providencea \\
\hline & & & & & & Raoultella \\
\hline & & & & & & Salmonella \\
\hline & & & & & & Shigella \\
\hline
\end{tabular}


Table 13. Complete taxonomic descriptions of bacterial genera obtained from the skin mucous of age-0 juvenile suckers collected in or near Upper Klamath Lake, Oregon, or Clear Lake Reservoir, Modoc County, California, July 28 to September 18, 2008. -Continued

\begin{tabular}{|c|c|c|c|c|c|c|}
\hline Phylum & Class & Subclass & Order & Suborder & Family & Genus \\
\hline \multirow[t]{6}{*}{ Proteobacteria } & Deltaproteobacteria & & Desulphovibronales & & Desulphovibrionaceae & Desulphovibrio \\
\hline & & & Desulfobacterales & & Desulfobacterales & Nitrospina \\
\hline & & & Desulfuromonales & & Geobacteraceae & Geobacter \\
\hline & & & Syntrophobacterales & & Syntrophobacteraceae & Syntrophobacter \\
\hline & & & Bedellovibrioales & & Bacteriovoracaceae & Bacteriovorax \\
\hline & Epsilonproteobacteria & & Campylobacterales & & Campylobacteraceae & Arcobacter \\
\hline Firmicutes & "Clostridia" & & Clostridiales & & Clostridiaceae & Clostridium \\
\hline \multirow[t]{13}{*}{ Firmicutes } & "Clostridia" & & Clostridiales & & "Gracilibacteraceae" & Gracilibacter \\
\hline & & & & & "Lachnospiraceae" & Bryantella \\
\hline & & & & & & Butyrivibrio \\
\hline & & & & & "Ruminococcaceae" & Ruminococcus \\
\hline & & & & & & Acetivibrio \\
\hline & & & & & & Anaerotruncus \\
\hline & & & & & & Faecalibacterium \\
\hline & & & & & & Papillibacter \\
\hline & & & & & & Sporobacter \\
\hline & & & & & & Subdoligranulum \\
\hline & & & & & Veillonellaceae & Succiniclasticum \\
\hline & & & & & Incertae Sedia XI & Sedimentibacter \\
\hline & & & & & Incertae Sedia XII & Fusibacter \\
\hline
\end{tabular}


Table 13. Complete taxonomic descriptions of bacterial genera obtained from the skin mucous of age-0 juvenile suckers collected in or near Upper Klamath Lake, Oregon, or Clear Lake Reservoir, Modoc County, California, July 28 to September 18, 2008.-Continued

\begin{tabular}{|c|c|c|c|c|c|c|}
\hline Phylum & Class & Subclass & Order & Suborder & Family & Genus \\
\hline Firmicutes & "Clostridia" & & Clostridiales & & Incertae Sedia XIII & Anaerovorax \\
\hline \multirow[t]{3}{*}{ Actinobacteria } & Actinobacteria & Acidimicrobidae & Acidimicrobiales & Acidimicrobineae & Acidimicrobiaceae & Acidimicrobium \\
\hline & & Coriobacteridae & Coriobacteriales & Coriobacterineae & Coriobacteriaceae & Atopobium \\
\hline & & & & & & Collinsella \\
\hline \multirow[t]{8}{*}{ Acidobacteria } & Acidobacteria & & Acidobacteriales & & Acidobacteriaceae & Gp 1 \\
\hline & & & & & & $G p 3$ \\
\hline & & & & & & Gp 6 \\
\hline & & & & & & Gp 8 \\
\hline & & & & & & Gp 9 \\
\hline & & & & & & Gp 10 \\
\hline & & & & & & $G p 21$ \\
\hline & & & & & & Gp 22 \\
\hline \multirow[t]{9}{*}{ Bacteroidetes } & Bacteroidetes & & Bacteroidales & & Rikenellaceae & Alistipes \\
\hline & & & & & Prevotellaceae & Prevotella \\
\hline & & & & & Porphyromonadaceae & Dysgonomonas \\
\hline & Flavobacteria & & Flavobacteriales & & Flavobacteriaceae & Gelidibacter \\
\hline & & & & & & Polaribacter \\
\hline & & & & & & Gramella \\
\hline & & & & & & Robiginitalea \\
\hline & & & & & Cryomorphaceae & Fluviicola \\
\hline & & & & & & Owenweeksia \\
\hline
\end{tabular}


Table 13. Complete taxonomic descriptions of bacterial genera obtained from the skin mucous of age-0 juvenile suckers collected in or near Upper Klamath Lake, Oregon, or Clear Lake Reservoir, Modoc County, California, July 28 to September 18, 2008. Continued

\begin{tabular}{|l|l|l|l|l|l|l|}
\hline Phylum & Class & Subclass & Order & Suborder & Family & Genus \\
\hline Bacteroidetes & Sphingbacteria & & Sphingobacteriales & & Flexibacteraceae & Leeuwenhoekiella \\
\hline & & & & & Crenotrichaceae & Balneola \\
\hline & & & & & Salinibacter \\
\hline Gemmatimonadetes & Gemmatimonadetes & & Gemmatimonadales & & Gemmatimonadaceae & Gemmatimonas \\
\hline
\end{tabular}


Table 14. Example taxa in Cyanobacteria genus groups obtained from the skin mucous of age-0 juvenile suckers collected from Upper Klamath Lake, Oregon, and Clear Lake Reservoir, Modoc County, California, July 28-September 18, 2008.

[Taxa are listed as a link to taxonomic nomenclature used in this report and do not necessarily imply the occurrence of these genera in Upper Klamath Lake or Clear Lake Reservoir. The methods used in this study do not permit identification of taxa beyond the genus groups $(\mathrm{Gp})$ ]

\begin{tabular}{|l|l|l|}
\hline \multicolumn{1}{|c|}{ Family } & \multicolumn{1}{|c|}{ Genus } & \multicolumn{1}{c|}{ Example Taxa } \\
\hline I & Gp I & Anabaena, Calothrix, Rivularia \\
\hline IV & Gp IV & Leptolyngbya \\
\hline VII & Gp VIII & Cyanothece \\
\hline VIII & Gp VIII & $\begin{array}{l}\text { Myxosarcina, Pleurocapsa, } \\
\text { Stanieria, Xenococcus }\end{array}$ \\
\hline XIII & Gp XIII & Geitlerinema \\
\hline
\end{tabular}


Table 15. Outcome summary for age- 0 juvenile sucker samples collected for transforming grouth factor- $ß$ (TGF-ß) analysis in or near Upper Klamath Lake, Oregon, or Clear Lake Reservoir, Modoc County, California, July 28-September 18, 2008.

\begin{tabular}{|c|c|c|c|c|c|c|}
\hline Sample area & Sample dates & $\begin{array}{l}\text { Total sucker } \\
\text { samples } \\
\text { collected (n) }\end{array}$ & $\begin{array}{l}\text { Total sucker } \\
\text { samples not } \\
\text { appropriate for } \\
\text { analysis }(n)^{1}\end{array}$ & $\begin{array}{l}\text { Total sucker } \\
\text { samples } \\
\text { analyzed (n) }\end{array}$ & $\begin{array}{c}\text { Sample with no } \\
\text { detected TGF-ß } \\
\text { activity }^{2}\end{array}$ & $\begin{array}{l}\text { Sample with } \\
\text { detected TGF-ß } \\
\text { activity }^{3}\end{array}$ \\
\hline Agency Lake & $\begin{array}{l}\text { July 28-August 26, } \\
2008\end{array}$ & 4 & 1 & 3 & 2 & 1 \\
\hline Tulana Open Water & $\begin{array}{l}\text { July 29-September } \\
16,2008\end{array}$ & 39 & 8 & 31 & 8 & 23 \\
\hline $\begin{array}{l}\text { Tulana Submerged } \\
\text { Vegetation }\end{array}$ & $\begin{array}{l}\text { August 27- } \\
\text { September 16, } 2008\end{array}$ & 15 & 0 & 15 & 2 & 13 \\
\hline $\begin{array}{l}\text { Northern Region } \\
\text { Near Shore }\end{array}$ & $\begin{array}{l}\text { July 31-August 28, } \\
2008\end{array}$ & 34 & 17 & 17 & 12 & 5 \\
\hline $\begin{array}{l}\text { Northern Region } \\
\text { Off Shore }\end{array}$ & July 28-30, 2008 & 5 & 2 & 3 & 1 & 2 \\
\hline $\begin{array}{l}\text { Central Region Near } \\
\text { Shore }\end{array}$ & $\begin{array}{l}\text { July 31-August 26, } \\
2008\end{array}$ & 21 & 13 & 8 & 5 & 3 \\
\hline $\begin{array}{l}\text { Central Region Off } \\
\text { Shore }\end{array}$ & July 29-31, 2008 & 6 & 4 & 2 & 0 & 2 \\
\hline $\begin{array}{l}\text { Southern Region } \\
\text { Near Shore }\end{array}$ & August 11-26, 2008 & 25 & 5 & 20 & 13 & 7 \\
\hline $\begin{array}{l}\text { Southern Region } \\
\text { Off Shore }\end{array}$ & July 30, 2008 & 2 & 1 & 1 & 0 & 1 \\
\hline $\begin{array}{l}\text { Clear Lake } \\
\text { Reservoir }\end{array}$ & $\begin{array}{l}\text { September 16-18, } \\
2008\end{array}$ & 8 & 6 & 2 & 1 & 1 \\
\hline
\end{tabular}

${ }^{1}$ Samples obviously not spleen, of obvious poor quality, or with insufficient quality mRNA yield.

2TGF-ß and/or ß-Actin below detection threshold.

IIncludes Lost River, shortnose, Klamath largescale and unidentified suckers. 
Publishing support provided by the U.S. Geological Survey Publishing Network, Tacoma Publishing Service Center

For more information concerning the research in this report, contact the Director, Western Fisheries Research Center

U.S. Geological Survey, 6505 NE 65th Street

Seattle, Washington 98115

http://wfrc.usgs.gov/ 
